RFP-4604

Octoher 22. 1993
RFP-4604

UC-721 DEFENSE

WASTE MANAGEMENT

DOE/OSTI-4500 (Rev. 75)

\title{
PRELIMINARY ASSESSMENT OF REAL-TIME RADIOGRAPHY AND VISUAL CHARACTERIZATION FOR SELECTED WASTE CATEGORIES
}

\author{
D. L. Ziegler \\ R. V. Harder
}

EG\&G ROCKY FLATS, INC.

ROCKY FLATS PLANT

P. O. BOX 464

GOLDEN, COLORADO 80402-0464
PREPARED UNDER CONTRACT DE-AC04-90DE62349
FOR THE
AI.BUQUEROUE OPERATIONS OFFICE
U.S. DEPARTMENT OF ENERGY




\section{ACKNOWLEDGMENTS}

We wish to thank D. A. Burton for his support in the visual and physical examinations and K. S. Kosko for his support on the RTR inspecions. We also thank D. Splett for statistical evaluation of data as well as $G$. A. O'Leary and P. M. Arnold for their technical review of this document. 


\section{CONTENTS}

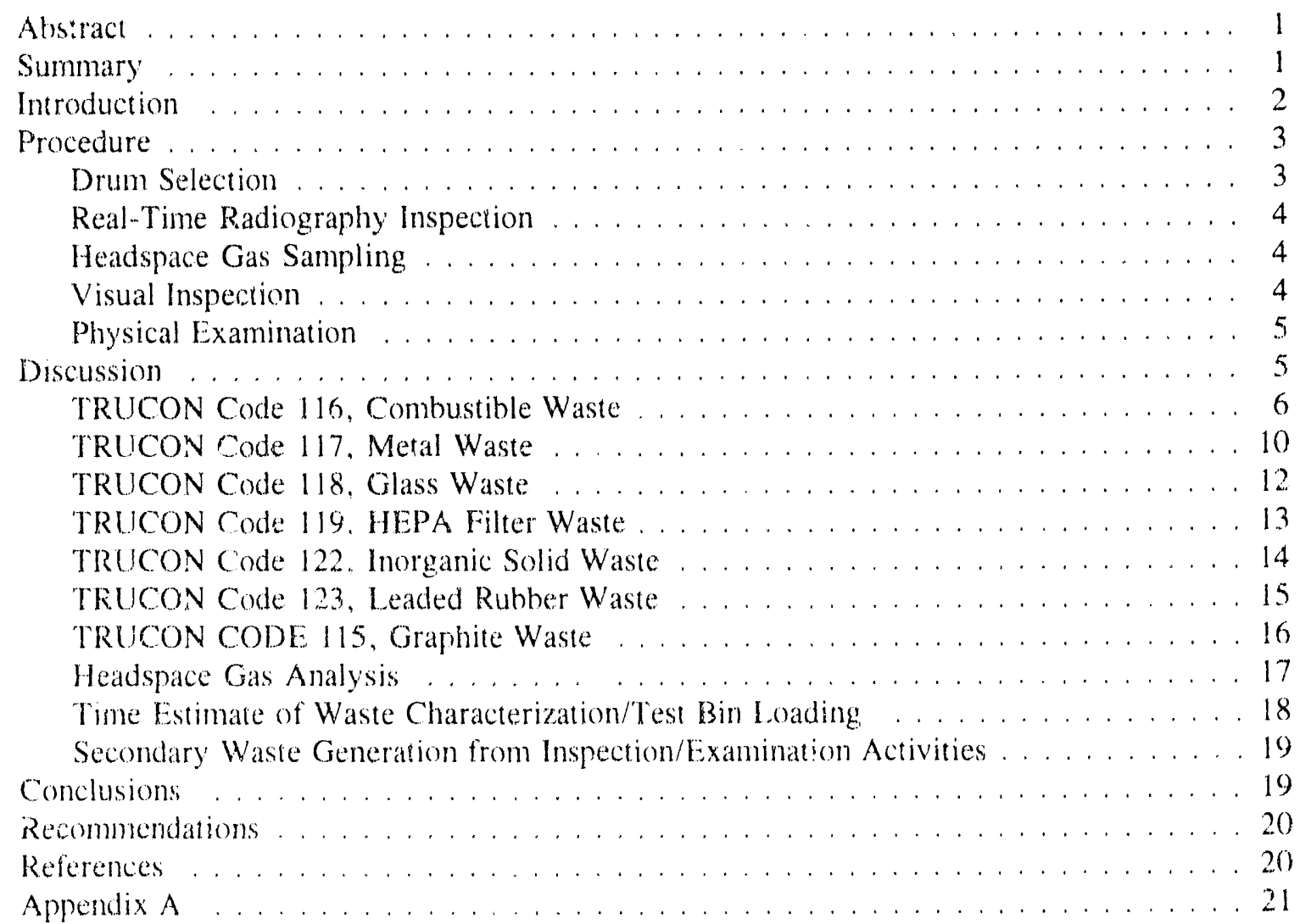


RFP-4604 


\title{
PRELIMINARY ASSIESSMENT OF REAL-TIME RADIOGRAPHY AND VISUAL CHARACTERIZATION FOR SELECTED WASTE CATEGORIES
}

\author{
D. L. Ziegler and $R \quad V$. Harder
}

\begin{abstract}
A preliminary study was performed at the Rocky Flats Plant to evaluate transuranic waste characterization methods utilizing Real-Time Radiography (RTR) and visual inspection of waste drums and packages. The characterization involves determining the amounts of specified waste materials for the WIPP bin-scale tests, such as plastic, cellulosic, steel, aluminum, rubber, solid inorganic, cement, and non-corroding metal. A physical examination and weighing of material is used to determine the actual composition of the waste. The study evaluated each method in terms of its ability to detect the presence of material components and the accuracy of estimating weights of components. RTR inspection of waste drums provides a suitable method for characterizing all waste categories tested in the study except for meral waste and combustible waste. Visual inspection, perhaps with the aid of a package RTR, is recommended for metal waste; and physical segregation and weighing of materials are needed for the combustible waste. Some data are provided $\mathrm{c} n$ the gas composition in waste packages, estimates of secondary waste generation produced during examination, and estimates of the time required for waste characterization.
\end{abstract}

\section{SUMMARY}

Tests were performed on selected drums of transuranic waste to: determine the feasibility of visual and Real-Time Radiography (RTR) inspection, obtain waste characterization information. and learn about homogeneity and packaging of selected waste categories. Headspace gas samples for 12 drums were taken from the large (55 gal.) bag and sent to the analytical laboratory to determine whether volatile organics were present and to identify gas composition. Nineteen drums were selected for testing from the following TRUCON codes and Identification Description Codes (IDCs).

$\begin{array}{cclc}\begin{array}{c}\text { TRUCON } \\ \text { Code }\end{array} & \text { IDC } & \text { Waste Type } & \text { Drums } \\ 116 & 831 & \text { Dry Combustibles } & 2 \\ 116 & 832 & \text { Wet Combustibles } & 3 \\ 116 & 833 & \text { Plastics } & 1 \\ 117 & 480 & \text { Light Metals } & 3 \\ 118 & 440 & \text { Glass } & 1 \\ 118 & 442 & \text { Raschig Rings } & 2 \\ 118 & 368 & \text { MgO Crucibles } & 1 \\ 119 & 342 & \text { HEPA Filters } & 2 \\ 122 & 438 & \text { Insulation } & 2 \\ 123 & 339 & \text { Leaded Rubber } & 1 \\ 115 & 300 & \text { Graphite } & 1\end{array}$

The RTR inspection was performed by six experienced operators observing each drum if waste and estimating composition of the contents. The technical foreman condensed this information to a single weighi composition estimate for the waste in each drum. The estimate was made by subtracting standard weight for the drum and rigid liner (if present) from gross weight of the drum.

For visual inspection, at least two operators in full-face respirators observed the individual bags and estimated the percentage of each material type present. The bags were weighed and subsequently subjected to a physical examination by segregating and weighing the individual materials. Physical examination was performed by operators working in supplied-air suits in the size red:ction vault

Visual inspection demonstrated inability of the experienced operators to detect some naterials in the waste. The detection of cellulosics in the 
combustibles was quite low, even though cellulosics represent $25 \%$ of that waste mixture (TRUCON Code 116). Because of the importance of cellubosics as a potential gas generator and the low level of detectability by visual inspection, physical examination is recommended for characterizing this type waste. Because of the safety concerns and labor requirements associated with cutting and removing tape from individual items in the metal waste category (TRUCON Code 1i7), it would be desirable to limit physical examination to the bin-scale iests only. If an operator training program is implemented using simulated waste, it may be possible to demonstrate ability of the operators to detect various types of metals and establish an estimating accuracy for waste composition percentages without completely unwrapping the items. This is the preferred approach for characterizing metal waste during bin loading.

The RTR inspection produced acceptable characterization data for TRUCON Codes 115 , $118,119,122$, and 123 waste. Because the RTR inspection is less labor-intensive and reduces personnel radiation exposure compared to visual inspection, it should be utilized where results are acceptable. Physical examination of these waste categories will be necessary during bin loading to establish the data base for accuracy of RTR inspection. The physical examination data will be used as the basis of waste characterization during the bin-scale program. Once correlation is established for RTR inspection, only drums indicating a high degree of uncertainty by R'TR inspection would be subjected to physical examination.

An estimate was made of the time required to characterize the waste visually and load a bin. Considering other necessary lasks in the vauit, a second shift would be required in the size reduction vault to pack one bin per week, on the average. The visual inspection and physical examination of the waste result in the generation of secondary low-level waste. This represents about $25 \%$ compared to the amount of waste inspected.
Of the waste examined, four drums were assigned an incorrect IDC. One drum of diy combustibles shou!d have been identified as wet combustibles because of the moisture content. The three drums of wet combustibles should have been identified as plastic because their plastic content exceeded $50 \mathrm{wt} \%$. It is significant, however, that all the material was within the correct TRUCON code and would have been acceptable for bin loading.

The headspace gas analysis indicated that all of these drums would have been acceptable from flammable gas and hazardous organic concentration criteria. However, greater than $1 \%$ hydrogen was detected in two drum bags, and the hydrogen gas concentration within the individual bags could approach the limits, depending on the number of bag layers.

\section{INTRODUCTION}

The first transuranic (TRU) waste shipped to the Waste Isolation Pilot Plant (WIPP) will be for the WIPP Experimental Program. The purpose of the Experimental Program is to determine the gas generation rates and gas generation potential after permanent storage at WIPP. The first phase of these tests will be performed at WIPP with test bins filled and sealed in accordance with the test plan for bin-scale tests. A second phase, the Alcove Test, will involve drummed waste placed in sealed rooms within WIPP.

A preliminary test was conducted at the Rocky Flats Plant (RFP) to evaluate potential methods for characterizing waste. Identification Description Codes (IDCs) for waste types were chosen because of their abundance on plant, as well as variability in drum loading techniques. The goal of this test was to evaluate the effectiveness of RTR inspection and visual inspection as characterization methods for waste. In addition, gas analysis of the headspace was conducted to provide an indication of the gas types generated.

It may be possible that sufficient knowledge regarding the waste placed into the test bins can be 
derived from an RTR inspection of the drum or from an external visual inspection of each bag. There is evidence, however, from previously videotaped waste characterization operations that both the RTR drum inspection and the external bag visual inspection may not be viable methods for characterizing some RFP waste.

There is some difficulty in using RTR inspection to discriminate between materials of very similar densities (e.g., paper and cloth versus plastic, or copper versus steel). Visual inspection from outside the bags is limited by:

- Multiple layers of plastic bags

- Residual acid causing bag discoloration

- Grease and dust adhering to the inside of bags

- PVC bags with limited transparency being used to bag line generated waste

- Yellow tape wrapping on items

- Opaque internal containers

The objective of these tests was to evaluate how well experienced RTR operators can estimate the waste composition in a drum without opening the drum and how well experienced waste operators can estimate waste composition in waste bags without opening the bags. The bag would then be opened, physically segregated by material type, and weighed. Data collected by visual inspection were compared with actual composition obtained by the physical examination. The waste composition from the physical examination was combined to obtain the drum content, which was compared to the composition obtained by RTR inspection.

Data collected during these tests will be useful in meeting several secondary objectives relevant to loading bins. One objective is to provide data useful in estimating the time required for visual inspection or physical examination of the waste. Another objective is to estimate secondary waste generation from waste characterization activities.

\section{PROCEDURE:}

The general steps necessary to implement this test include: Drum Selection. R'TR Examination,
Headspace Gas Sampling, Visual Inspection, and Physical Examination.

\section{Drum Selection}

Nineteen drums of waste were selected for this test, most of which came from the building where the RTR is located. This reduced the number of drum transfers. After R'TR inspection, the drums were transferred to another building for visual inspection and physical examiration. The drums selected were packaged within the previous two years, which is consistent with the definition for newly generated waste in the Bin-Scale Test Plan. ${ }^{1}$

The drums used in this test should reflect the quality of segregation and assignment of proper IDCs to the drums. The quantity of each type of waste selected roughly correspond to the quantities presently stored at RFP. Because some waste TRUCON Codes included IDCs that are somewhat different in waste material and packaging methods, the numbers selected for the test were increased out of proportion to the waste population. Even though the waste was selected primarily from one storage building, it had been generated in several buildings. The packages of waste were selected to represent typical plant operation. However, the waste types selected were primarily those anticipated as difficult to characterize because of the packaging and the mixture of components. The types of wastes selected were:

\begin{tabular}{|c|c|c|c|}
\hline $\begin{array}{l}\text { TRUCON } \\
\text { Code }\end{array}$ & $\underline{I D C}$ & Waste Type & Drum \\
\hline 116 & $\overline{831}$ & Dry Combustibles & 2 \\
\hline 116 & 832 & Wet Combustibles & 3 \\
\hline 116 & 833 & Plastics & 1 \\
\hline 117 & 480 & Light Metals & 3 \\
\hline 118 & 440 & $\begin{array}{l}\text { Glass (Non-Raschig } \\
\text { Rings) }\end{array}$ & \\
\hline 118 & 442 & Raschig Rings & 2 \\
\hline 118 & 368 & $\mathrm{MgO}$ Crucibles & 1 \\
\hline 119 & 342 & HEPA Filters & 2 \\
\hline 122 & 438 & Insulation & \\
\hline 123 & 339 & $\begin{array}{l}\text { Leaded Dry Box } \\
\text { Gloves }\end{array}$ & \\
\hline 115 & 300 & Graphite & \\
\hline
\end{tabular}




\section{Real-Time Radiography Inspection}

Each drum was subjected to RTR inspection by six experienced RTR operators, and all recorded their observations as to the waste composition. The data generated were then reviewed by a technical foreman who also reviewed the RTR tapes and generated one estimated composition for each drum. This procedure combined the broad waste inspection experience of the RTR operator and understanding of the characterization program objectives of the technical foreman. This combination of knowledge was considered necessary to represent the $\mathrm{RTR}$ inspection performance once the operators received the necessary instruction and training.

Basically, the procedure involved subtracting standard weights of the drum and rigid liner (if present) from the gross weight to obtain net weight of the waste. In estimating weight composition of the waste, standard weights were used for various sizes of plastic bags, plastic bottles, and plastic clamshells used as packaging elements. Standard weight compositions were used for leaded rubber dry box gloves and several sizes of HEPA filters to allow conversion of those waste IDCs to component materials. The data on each drum of waste were then compiled for comparison with the information generated by physical inspection of the drum contents.

\section{Headspace Gas Sampling}

A gas sample was taken from the headspace of the large bag within the drum. The objective of analyzing the headspace was to determine whether volatiles were close to the limits proposed by the WIPP No Migration Variance Determination. ${ }^{2}$ The sampling was conducted using a hypodermic needle, manifold assembly, and vacuum pump. A single 10 -mi sample was drawn from inside the large bag. 'This sample was sent to the laboratory' for analysis. During this phase, the operators wore paper coveralls and full-face respirators. The work was perfomed in the air lock area of the size reduction vault (Figure 1).

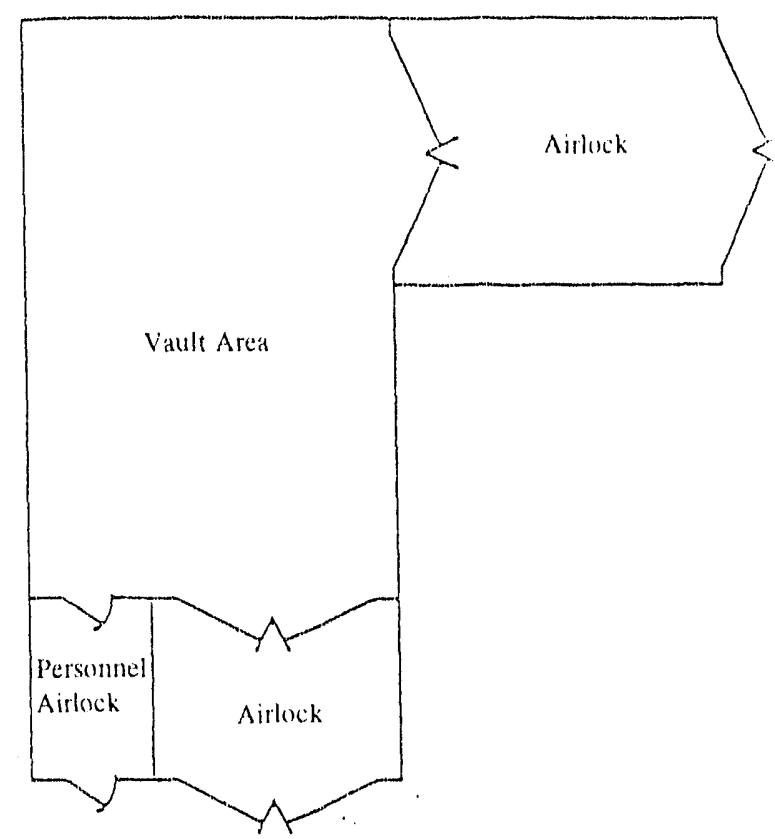

FIGURE 1. Size Rediction Facility

\section{Visual Inspection}

The waste material types to be identified as listed in the Bin-Scale Test Plan ${ }^{1}$ are: cellulosics, plastic, rubber, corroding metal/steel, corroding metal/aluminum, non-corroding metal, solid inorganics, inorganic sludges, and cements. For the five drums of wet and dry combustibles, the latex (surgeon's gloves) was included with the plastic. The classification of latex was subsequently clarif.ed, and latex was includeci with the rubber category for all remaining waste examined.

During the visual examination, the operators removed individual bags or items from the main bag for inspection. They numbered the bags and estimated the quantity and type of each component material within the individual bags. These estimates and bag numbers were recorded. Bags in the first two drums were marked with a grease pencil, but the markings were inadvertently wiped off before the physical segregation was completed. For later drums, a felt-tipped marker was used, which worked much better. Whenever contamina- 
tion was discovered on the outside of the inner individual bags, visual examination was halted and the remairing contents were moved into the vault for processing.

\section{Physical Examination}

Physical examination took place within the vault portion of the size reduction facility by operators wearing supplied-air suits. An intercom system provided communication between the operators and personnel recording the data. The bags were opened in numerical order and completely segregated. Each type of waste material was weighed and the information recorded. Records were kept outside the vault area for contamination control. After the waste was weighed, it was replaced in the original drum. When the drum was full, it was sealed and removed from the area. This process continued until all bags were opened and examined. Operators were allowed a maximum of 2.5 hours at a time in the supplied-air suits. If bags remained to be examined, a new crew of operators entered the vault to complete the work. The data generated by the visual inspection and physical examination are contained in Appendix A. Each bag was numbered consecutively followed by the alpha character indicating the material type and the last two digits of the drum number.

\section{DISCUSSION}

These preliminary tests involved inspecting only 19 drums representing $11 \mathrm{IDCs}$, which fall into seven TRUCON codes. The TRUCON codes are a more general waste classification system, and several IDCs may fall within a given TRUCON code. For some IDCs and TRUCON codes, only one drum was selected. Therefore, the data generated are preliminary in that the sample size for categories of waste types was very' small. Also, drums of waste were not strictly selected on a random basis. The intended use of these tests was to provide some information on how well each waste category was segregated in terms of types of material. It was also io indicate feasibility of RTR inspection and visual inspection for characterizing specific categories of material. Part of the benefit from this work was the learning process for the specific operations performed.

Because the RTR inspection information involves a drum of waste rather than individual bags, there are far fewer data points and statistical analysis of the RTR data is not practical. The RTR data are compared directly on either an individual drum basis or average of drums within a TRUCON code.

Even though visual inspection data are somewhat limited, they were evaluated statistically and analyzed for general information about waste packaging and viability of specific operations and inspection methods. The data generated on visual inspection, using the physical examination as the actual waste composition, resulted in four types of data sets for each component material for the waste materials tested:

$\begin{array}{ccc}\text { Case } & \begin{array}{c}\text { Visual } \\ \text { Inspection }\end{array} & \begin{array}{c}\text { Physical } \\ \text { Examination }\end{array} \\ 2 & \text { Value } & \text { Value } \\ 3 & \text { Value } & \text { Zero } \\ 4 & \text { Zero } & \text { Value } \\ \text { Zero } & \text { Zero }\end{array}$

A statistical analysis can be applied to the first two cases. However, Case 3 data are more an indication of the ability to detect by visual inspection a given component, rather than data for estimating, accuracy. The data analysi has, therefore, been considered in two parts: (1) viability of the characterization method based on the ability to detect the presence of material within the bag, and (2) accuracy of the visual inspection $f$. imating the amount of each material type. One would only be interested in the accuracy of the estimates if the ability exists to detect significant quantities of material types.

Major factor's for assessing viability of the characterization method are: (1) the amount of a material, such as cellulosics, within a given TRUCON code, combined with the gas generation potential for that material and (2) ability of the operator to detect presence of the component 


\section{RFP-4604}

material. For example, a low level of detection may be acceptable where the quantity of a component material is very small and the gas generation potential for that component material is low. However, a high level of detection may be necessary where the amount of a component material is significant and that material has high gas generation potential.

To assess the detectability of component materials, the following formulas are presented for the number detection index (NDI) and weight detection index (WDI):

$$
\operatorname{NDl}(\%)=\frac{\mathrm{NiD}}{\mathrm{NiP}} \times 100
$$

$\mathrm{NiD}=$ Number of bags where component $(i)$ was detected

NiP $=$ Number of bags containing component $(i)$

$$
\mathrm{WDI}(\%)=\frac{\mathrm{WiD}}{\mathrm{WiP}} \times 100
$$

WiP $=$ Actual weight of component $i$ in bags where its presence was detected

WiP $=$ Actual weight of component $i$ in all bags where it was present

If the average weight of the material is greater in the bags where it was detected than in bags where it was undetected, the WDI will be larger than the NDI. The WDI is somewhat more complex to define, but is a better reflection as to the amount of actual material present when it is detected. It should be pointed out that the WDI is not a measure of how much material was aciually estimated by visual inspection; it is only a measure of how much was there when its presence was detected.

If the detection index, combined with gas generation rates and percent of the component materials, leads to the conclusion that visual characterization is a viable method, the accuracy of the visual inspection will need to be addressed. Fven though the data are limited, a mean and standard deviation were calculated for the visual inspection. The mean is a correction that must be applied to the estimated value to correct for the over- or under-estimating bias. All the significant data were calculated using Cases 1 and 2 of the data sets, where estimated values were given for the component material. The mean is calculated by using the values obtained, subtracting the actual value from the estimated value. Therefore, a plus mean indicates estimated values are greater than actual values, and the estimated value would have to be decreased due to overestimating bias. If the data are normally distributed, one standard deviation would indicate a confidence limit of about $68 \%$. If a $95 \%$ confidence limit is required, one would have to consider accuracy within two standard deviations.

\section{TRUCON Code 116, Combustible Waste (IDC 831, 832, 833)}

Six drums were inspected within this TRUCON code: two dry combustibles (IDC 831), three wet combustibles (IDC 832), and one plastic (IDC 833). A total of 53 packages were visually inspected and physically examined. The package size varied from one 55 -gallon bag weighing 32.63 $\mathrm{kg}$ to a small package of $0.21 \mathrm{~kg}$.

The data necessary for visual inspection method viability evaluation are presented in Table 1 . The gas generation information therein is taken from the Test Plan Addendum 1, WIPP Bin-Scale TRU Waste Tests. ${ }^{1}$

The cellulosic material is the only component found in the combustible material examined having a high gas generation potential (for microbial action). The cellulosic was $25.1 \%$ of the total weight of waste material. The visual inspection NDI for cellulosic was $39 \%$. The high gas generation potential, combined with a significant amount present and a low number detection index, should lead to the conclusion that estimating by visual inspection provides linited characterization data for the bin-scale tests. When cellulosics were detected, the amount averaged $0.43 \mathrm{~kg}$ cellulosic per bag. However, when cellulosics were not 
TABLE 1. Waste Detection for Visual Inspection

\begin{tabular}{|c|c|c|c|c|c|c|c|c|c|}
\hline \multirow[b]{2}{*}{$\begin{array}{l}\text { Trucon } \\
\text { Code }\end{array}$} & \multirow{2}{*}{$\begin{array}{c}\text { Component } \\
\text { Material } \\
\end{array}$} & \multirow[b]{2}{*}{$\begin{array}{c}\text { Component } \\
(\%)\end{array}$} & \multicolumn{3}{|c|}{ Gas Generation Potential } & \multicolumn{2}{|c|}{ Detection Index } & \multirow{2}{*}{$\begin{array}{c}\text { Average } \\
\text { Actual } \\
\text { When } \\
\text { Detected } \\
(\mathrm{kg})\end{array}$} & \multirow{2}{*}{$\begin{array}{c}\begin{array}{c}\text { Component } \\
\text { Weight }\end{array} \\
\text { When Not } \\
\begin{array}{c}\text { Detected } \\
\text { (kg) }\end{array}\end{array}$} \\
\hline & & & Radiolytic & Microbial & Corrosion & $\begin{array}{l}\text { NDI } \\
(\%)\end{array}$ & $\begin{array}{l}\text { WDI } \\
(\%)\end{array}$ & & \\
\hline 116 & $\begin{array}{l}\text { Cellulosic } \\
\text { Plastic } \\
\text { Rubber } \\
\text { Solid Inorganic } \\
\text { Cement }\end{array}$ & $\begin{array}{r}25.1 \\
64.2 \\
3.3 \\
0.2 \\
7.2\end{array}$ & $\begin{array}{l}\text { Low } \\
\text { Low } \\
\text { Low } \\
\text { Low } \\
\text { Mod }\end{array}$ & $\begin{array}{l}\text { High } \\
\text { Low } \\
\text { Low } \\
\text { Low }\end{array}$ & $\begin{array}{l}\cdots \\
\cdots \\
\cdots \\
\cdots \\
\cdots\end{array}$ & $\begin{array}{r}30 \\
100 \\
100 \\
0 \\
50\end{array}$ & $\begin{array}{r}7 \\
100 \\
100 \\
0 \\
2\end{array}$ & $\begin{array}{l}0.43 \\
2.04 \\
0.33 \\
-- \\
0.23\end{array}$ & $\begin{array}{l}3.41 \\
\cdots \\
0.28 \\
11.34\end{array}$ \\
\hline 117 & $\begin{array}{l}\text { Cellulosic } \\
\text { Plastic } \\
\text { Corr. Metal/Steel } \\
\text { Corr. Metal/Ai } \\
\text { Non-Corr. Metal } \\
\text { Cement }\end{array}$ & $\begin{array}{r}0.5 \\
20.3 \\
66.7 \\
5.8 \\
1.8 \\
4.7\end{array}$ & $\begin{array}{c}\text { Low } \\
\text { Low } \\
\ldots \\
\ldots \\
\text { Mod }\end{array}$ & $\begin{array}{c}\text { High } \\
\ldots \\
-- \\
-- \\
\text { - } \\
\text { Low }\end{array}$ & $\begin{array}{c}\ldots \\
\text { High (Wet) } \\
\text { High } \\
\text { Low } \\
\end{array}$ & $\begin{array}{r}100 \\
100 \\
85 \\
50 \\
0 \\
50\end{array}$ & $\begin{array}{r}100 \\
100 \\
88 \\
29 \\
0 \\
84\end{array}$ & $\begin{array}{l}0.28 \\
1.02 \\
1.95 \\
0.91 \\
\cdots \\
2.27\end{array}$ & $\begin{array}{l}\cdots \\
2.28 \\
2.27 \\
1.02 \\
0.45\end{array}$ \\
\hline 118 & $\begin{array}{l}\text { Plastic } \\
\text { Non-Corr. Metal } \\
\text { Solid Inorganic } \\
\text { Inorg. Sludge }\end{array}$ & $\begin{array}{r}8.4 \\
0.2 \\
90.6 \\
0.8 \\
\end{array}$ & $\begin{array}{c}\text { Low } \\
\ldots \\
\text { Low } \\
\text { Mod }\end{array}$ & $\begin{array}{l}\cdots \\
\cdots \\
\text { Low } \\
\text { Low }\end{array}$ & $\begin{array}{c}\cdots \\
\text { Low } \\
\ldots \\
\cdots\end{array}$ & $\begin{array}{c}92.6 \\
100 \\
76.47 \\
0\end{array}$ & $\begin{array}{c}98.5 \\
100 \\
86.5 \\
0 \\
\end{array}$ & $\begin{array}{l}0.72 \\
0.10 \\
4.57 \\
\end{array}$ & $\begin{array}{l}0.14 \\
2.22 \\
1.66 \\
\end{array}$ \\
\hline 119 & $\begin{array}{l}\text { Cellulosic } \\
\text { Plastic } \\
\text { Rubber } \\
\text { Corr Metal/Al } \\
\text { Solid Inorganic } \\
\text { Other Organic }\end{array}$ & $\begin{array}{r}60.4 \\
20.4 \\
1.3 \\
8.4 \\
6.2 \\
3.3 \\
\end{array}$ & $\begin{array}{l}\text { Low } \\
\text { Low } \\
\text { Low } \\
\text { Low } \\
\text { Low }\end{array}$ & $\begin{array}{c}\text { High } \\
-- \\
\text { Low } \\
-. \\
\text { Low } \\
\text { Low }\end{array}$ & $\begin{array}{c}\cdots \\
\ldots \\
\text { High } \\
\cdots \\
\cdots\end{array}$ & $\begin{array}{r}100 \\
90 \\
100 \\
100 \\
10) \\
100 \\
\end{array}$ & $\begin{array}{r}100 \\
98 \\
100 \\
100 \\
100 \\
100 \\
\end{array}$ & $\begin{array}{l}1.44 \\
0.52 \\
0.03 \\
0.20 \\
0.15 \\
0.16 \\
\end{array}$ & $\begin{array}{l}\cdots \\
0.10 \\
- \\
\cdots \\
- \\
-\cdots \\
\end{array}$ \\
\hline 122 & $\begin{array}{l}\text { Plastic } \\
\text { Non-Corr. Metal } \\
\text { Solid Inorganic }\end{array}$ & $\begin{array}{r}4.0 \\
5.7 \\
90.3\end{array}$ & $\begin{array}{l}\text { Low } \\
\text { Low }\end{array}$ & $\begin{array}{l}\cdots \\
\cdots \\
\text { Low }\end{array}$ & Low & $\begin{array}{r}100 \\
50 \\
100 \\
\end{array}$ & $\begin{array}{r}100 \\
5 \\
100 \\
\end{array}$ & $\begin{array}{l}0.50 \\
0.15 \\
9.14\end{array}$ & 2.72 \\
\hline 123 & $\begin{array}{l}\text { Cellulosic } \\
\text { Plastic } \\
\text { Rubber } \\
\text { Solid Inorganic }\end{array}$ & $\begin{array}{r}2.4 \\
9.0 \\
32.9 \\
55.7\end{array}$ & $\begin{array}{l}\text { Low } \\
\text { Low } \\
\text { Low } \\
\text { Low }\end{array}$ & $\begin{array}{l}\text { High } \\
\text { Low } \\
\text { Low }\end{array}$ & $\begin{array}{l}\cdots \\
\cdots \\
\cdots\end{array}$ & $\begin{array}{r}0 \\
0 \\
100 \\
100\end{array}$ & $\begin{array}{r}0 \\
0 \\
10(1) \\
100\end{array}$ & $\begin{array}{l}\cdots \\
1.58 \\
2.68\end{array}$ & $\begin{array}{l}1.25 \\
0.44 \\
\cdots \\
\cdots\end{array}$ \\
\hline
\end{tabular}

detected, the amount present averaged $3.14 \mathrm{~kg}$ per bag. This may be contrary to what one would expect. However, when cellulosics were not detected, they were present in bags of greater total weight. For example, one bag of $32.63 \mathrm{~kg}$ total weight contained $17.66 \mathrm{~kg}$ of cellulosics, which were not detected by visual inspection from outside the bag. Because of the greater weights of celluiosics not being detected, the WDI for cellulosics was only $7.2 \%$.

Cements are rated as moderate for radiolytic gas generation. Cement (oil dry) was present in two bags of waste representing about $7.2 \%$ of the total waste inspected in TRUCON Code 116 material.
The cement was detected by visual inspection from outside the bag in one of the two bags where it was ?rese:at, which resulted in an NDI of $50 \%$. However, the bag where it was detected contained $0.23 \mathrm{~kg}$ of cement, and the bag where it was not detected contained $11.34 \mathrm{~kg}$ of cement, resulting in WDI of $2 \%$.

Visual mspection of TRUCON Code 116 waste resulted in $13.3 \%$ being listed as unknown. The Test Plan Addendum 1 indicated that up to 25 wt \% unknown material would be acceptable for the bin-scale tests. ${ }^{1}$ The visual inspection method provided an acceptable level for unknown material for waste examined in TRUCON Code 116. 
TABLE 2. Accuracy and Precision Data for Visual Inspection

\begin{tabular}{|c|c|c|c|c|}
\hline \multirow[b]{2}{*}{$\begin{array}{l}\text { Trucon } \\
\text { Code }\end{array}$} & \multirow[b]{2}{*}{$\begin{array}{c}\text { Conıponent } \\
\text { Material }\end{array}$} & \multirow[b]{2}{*}{$\begin{array}{c}\text { Component } \\
(\%)\end{array}$} & \multicolumn{2}{|c|}{ Statistical Data } \\
\hline & & & $\begin{array}{c}\text { Mean } \\
(\%)\end{array}$ & $\begin{array}{c}\text { Standard } \\
\text { Deviation } \\
(\%)\end{array}$ \\
\hline 116 & $\begin{array}{l}\text { Cellulosic } \\
\text { Plastic } \\
\text { Rubber } \\
\text { Solid Inorganic } \\
\text { Cement }\end{array}$ & $\begin{array}{r}2.5 .1 \\
64.2 \\
3.3 \\
0.2 \\
7.2\end{array}$ & $\begin{array}{r}+39 \\
-497 \\
+23 \\
\ldots \\
-53\end{array}$ & $\begin{array}{r}84 \\
1081 \\
134 \\
\ldots \\
\cdots\end{array}$ \\
\hline 117 & $\begin{array}{l}\text { Cellulosic } \\
\text { Plastic } \\
\text { Corr. Metal/Steel } \\
\text { Corr. Metal/Al } \\
\text { Non-Corr. Metal } \\
\text { Cement }\end{array}$ & $\begin{array}{r}0.5 \\
20.3 \\
66.7 \\
5.8 \\
1.8 \\
4.7\end{array}$ & $\begin{array}{r}+85 \\
-250 \\
+10 \\
+51 \\
- \\
-19 \\
\end{array}$ & $\begin{array}{r}- \\
563 \\
43 \\
\cdots \\
\cdots \\
\cdots\end{array}$ \\
\hline 118 & $\begin{array}{l}\text { Plastic } \\
\text { Non-Corr. Metal } \\
\text { Solid Inorganic } \\
\text { Inorg. Sludge }\end{array}$ & $\begin{array}{r}8.4 \\
0.2 \\
90.6 \\
0.8\end{array}$ & $\begin{array}{r}-20 \\
-530 \\
+5 \\
-\end{array}$ & $\begin{array}{r}304 \\
267 \\
13 \\
\cdots\end{array}$ \\
\hline 119 & $\begin{array}{l}\text { Cellulosic } \\
\text { Plastic } \\
\text { Rubber } \\
\text { Corr. Metal/Al } \\
\text { Solid Inorganic } \\
\text { Other Organic }\end{array}$ & $\begin{array}{r}60.4 \\
20.4 \\
1.3 \\
8.4 \\
6.2 \\
3.3\end{array}$ & $\begin{array}{r}+3 \\
-35 \\
0 \\
0 \\
+9 \\
+29\end{array}$ & $\begin{array}{r}9 \\
69 \\
0 \\
0 \\
28 \\
- \\
\end{array}$ \\
\hline 122 & $\begin{array}{l}\text { Cellulosic } \\
\text { Plastic } \\
\text { Non-Corr. Metal } \\
\text { Solid inorganic }\end{array}$ & $\begin{array}{r}4.0 \\
5.7 \\
90.3\end{array}$ & $\begin{array}{r}+100 \\
-81 \\
+40 \\
-7\end{array}$ & $\begin{array}{l}\cdots \\
11 \\
\cdots \\
33\end{array}$ \\
\hline 123 & $\begin{array}{l}\text { Cellulosic } \\
\text { Plastic } \\
\text { Rubber } \\
\text { Solid Inorganic }\end{array}$ & $\begin{array}{r}2.4 \\
9.0 \\
32.6 \\
55.7\end{array}$ & $\begin{array}{r}\cdots \\
+\cdots \\
+13 \\
+13\end{array}$ & $\begin{array}{c}\cdots \\
\cdots \\
9\end{array}$ \\
\hline
\end{tabular}

Because of the low (7.2\%) WDI for cellulosics and to a lesser extent the low ( $2 \%$ ) WDI for cement, visual inspection from outside the bags is of limited value as a characterization method for TRUCON Code 116 waste.

The data on mean and standard deviation for each component are presented in Table 2. However, this data should be considered unimportant because of the low detectability, as discussed above.

Table 3 presents the total material estimated by visual inspection and the actual amount as determined by physical examination on the basis of each of the six drums. The weight data presented in Table 3 includes 55-gallon bags and fiber liners (if present). The liners were not included in the bag data in Tables 1 and 2 except for drums containing only one bag.

Each of the two drums of dry combustibles (IDC 831) contained only a single 55-gallon bag of waste. The visual estimate resulted in greater than 50 wt \% of the material being misidentified and an average of $39 \%$ of the waste listed as unknown. One drum (No. 67771) of dry combustibles was assigned an incorrect IDC; it should have been identified as wet combustibles (IDC 832) because of the moisture content. It should be noted, however, that the classification of waste as wet or 
TABLE 3. Visual and Physical Characterization Results for Trucon Code 116 Waste

\begin{tabular}{|c|c|c|c|c|c|}
\hline & & Visual & Physical & Error hy $v_{i}$ & Inspection \\
\hline & $\begin{array}{l}\text { Compontent } \\
\text { Material }\end{array}$ & $\begin{array}{l}\text { Inspection } \\
\text { (kg) }\end{array}$ & $\begin{array}{l}\text { Examination } \\
(\mathrm{kg})\end{array}$ & $(\mathrm{kg})$ & $(\%)$ \\
\hline Drum 67771 & Cellulosic & $\ldots$ & 17.60 & -17.66 & $-1(0) .0$ \\
\hline IDC 831 & Plastic & 16.31 & 14.97 & +1.34 & +9.0 \\
\hline Dy Comb. & Unkenow'n & 16.32 & $\cdots$ & +16.32 & $\cdots$ \\
\hline & & 32.63 & $32,6,3$ & \pm 17.66 & $\pm \$ 4.2$ \\
\hline Dnum 69645 & Eellulesic & 2.17 & 1.3 .75 & -11.58 & -84.2 \\
\hline $1 D^{\prime} 8: 1$ & Plastic & 15.49 & 9.07 & +6.42 & +70.8 \\
\hline Dry Comb & Unkrown & 5.16 & $\cdots$ & 1.5.16 & $\cdots$ \\
\hline & & 22.82 & .22 .82 & \pm 11.58 & \pm 51.1 \\
\hline Drum 60742 & Cellulosic & 0.61 & 1.90 & -1.29 & -5.7 \\
\hline $\begin{array}{l}\text { IDC } 832 \\
\text { Wes couth }\end{array}$ & & & & +1.29 & \\
\hline & & 22.76 & 77.76 & \pm 1.29 & \pm 5.7 \\
\hline Drum 67988 & Celfulosic & $\cdots$ & 4.17 & -4.17 & -100.0 \\
\hline $\operatorname{IDC} 832$ & Plastic & 42.11 & 26.63 & +15.48 & +58.1 \\
\hline Wet Comb. & Cement & $\cdots$ & 12.34 & -11.34 & -100.0 \\
\hline & & 42.11 & 42.11 & \pm 15.48 & \pm 36.8 \\
\hline Drum 69869 & Plastic & 22.66 & 22.66 & 0.0 & 0.0 \\
\hline & & 22.66 & 22.60 & 0.0 & 0.0 \\
\hline Dnum 70260 & Cellulosic & 3.58 & 5.25 & -1.67 & -31.8 \\
\hline $1 D C 833$ & Plastuc. & 11.10 & 12.38 & -1.22 & -9.9 \\
\hline Plastic & Rubber & 8.56 & 5.31 & +3.25 & +61.2 \\
\hline 21 Bags & Solid Inorganic & & 0.28 & $\cdots 0.28$ & -100.0 \\
\hline & Cement & 0.15 & 6.23 & -0.08 & -34.8 \\
\hline & & 23.45 & 23.4 .5 & \pm 3.25 & \pm 13.9 \\
\hline Average of & Cellutosk & 3.06 & 7.12 & -6.06 & -85.1 \\
\hline above & Plastio & 21.65 & 17.76 & +3.89 & +21.9 \\
\hline 6 Dnums & Rublerer & 1.42 & 0.88 & +0.54 & +61.4 \\
\hline & Shold Irwrganto & $\cdots$ & 0.05 & -0.05 & -100.0 \\
\hline & Cement & 0.03 & 1.93 & -1.90 & -98.4 \\
\hline & Linknomn & 3.58 & $\cdots$ & +3.58 & $\cdots$ \\
\hline & & 27.74 & 27.74 & \pm 8.01 & \pm 28.9 \\
\hline
\end{tabular}




\section{RFP-4604}

dry is based purely on the judgment of the operator who generates the waste.

The three drums of wet combustibles (IDC 832) contained 12,6, and 15 bags per drum. Because there were more smaller bags, the amount of misidentified material per drum varied from 0 to $37 \%$. If a drum contains a single material, such as Drum 67869 , the ability to estimate composition by visual inspection is improved. Each of these three drums were also assigned an incorrect IDC. They should have been assigned IDC 833 (plastic) because the plastic content for each drum exceeded 50 wt \%. However, these three drums and Drum 67771 (dry combustibles) were in the same TRUCON code and, therefore, would have been assumed arceptable for bin loading.

The one drum of IDC 833 (plastic) contained 21 individual bags, which varied in weight from 0.22 to $7.03 \mathrm{~kg}$. The proportion of material misidentified by visual inspection in this drum was $13.9 \%$.

The RTR inspection was not used to estimate the weight composition of TRUCON Code 116 waste. This was due to RTR's limited ability to distinguish between paper, plastic and latex gloves and the extent of their mixture in the combustible waste. The RTR inspection information was used in confirmation of WIPP criteria. Results of the RTR inspections were made available for review by the operators conducting the visual inspection.

Physical examination of TRUCON Code 116 waste will provide a high degree of confidence of the characterization data for this type waste. RTR inspection of TRUCON Code 116 waste would result in a large range of inaccuracy of the characterization data. The tests conducted on the visual inspection method of characterization resulted in significant inaccuracies. As presented in Table 3, the results of the average drum indicated 85 and $98 \%$ errors in estimated values for cellulosics and cements, respectively. Cellulosic is expected to have a high gas generation potential, and the cements are expected to have a roderate potential for gas generation; other components are listed as low gas generators.

\section{TRUCON Code 117, Metal Waste (IDC 480)}

Three drums of IDC 480 (light metal) were selected for evaluation. One drum (No. 65769) exhibited contamination on the outside of the individual bags. Therefore, it was not subjected to estimating by visual inspection. Drum 63389 exhibited contamination outside the last six individual bags. The last six bags were not visually inspected. Thirteen individual bags from two drums were visually inspected. The drum contents were physically examined, and the results are presented in Table 4.

As indicated in Table 1, the material types of primary importance because of the high gas generation potential are: cellulosics (due to microbial action), corroding metal/aluminum (dice to corrosion), and corroding metai/steel (due to corrosion under wet conditions). Cements also are listed as having moderate gas generation potential. The corroding metal/steel represents $66.7 \%$ of this waste tested, the corroding metal/aluminum represents $5.8 \%$, and cellulosics is a very minor component at $0.5 \%$. The detection index for visual inspection for cellulosics was $100 \%$. However, only one package contained cellulosics, and this appears to be in.ufficient for testing the viability of visual inspection.

The number detection index for aluminum was $50 \%$. Only two packages contained aluminum; one was detected and one was not. However, the package containing the larger amount was not detected, resulting in a weight detection index of $28.6 \%$. For corroding metal/steel, which represents the major portion $(66.7 \%)$ of the light metal tested, the NDI for visual inspection was $85 \%$ and the WDI was $88 \%$.

The data for cellulosics and aluminum is insufficient for making a decision on viability of the visual inspection characterization method without further method development. The WDI for corroding metal/steel ( $88 \%$ ) may indicate hat visual characterization could be used. The NDI and WDI for coinents was 50 and $84 \%$, 
TABLE 4. Visual and Physical Characterization Results for Trucon Code 117 Waste

\begin{tabular}{|c|c|c|c|c|c|}
\hline & \multirow{2}{*}{$\begin{array}{l}\text { Component } \\
\text { Material }\end{array}$} & \multirow{2}{*}{$\begin{array}{c}\text { Visual } \\
\text { Inspection } \\
(\mathrm{kg})\end{array}$} & \multirow{2}{*}{$\begin{array}{c}\text { Physical } \\
\text { Examination } \\
(\mathrm{kg})\end{array}$} & \multicolumn{2}{|c|}{$\begin{array}{c}\text { Error by Visual } \\
\text { Inspection }\end{array}$} \\
\hline & & & & $(\mathrm{kg})$ & $(\%)$ \\
\hline \multirow{7}{*}{$\begin{array}{l}\text { Drum } 63389 \\
\text { IDC } 480 \\
\text { Metal } \\
14 \text { Bags }\end{array}$} & \multirow{7}{*}{$\begin{array}{l}\text { Celluiosic } \\
\text { Plastic } \\
\text { Corr. Metal/Steel } \\
\text { Corr. Metal/Al } \\
\text { Non-Corr. Metal } \\
\text { Cemeni }\end{array}$} & 3.98 & 2.45 & +1.53 & +62.4 \\
\hline & & 3.16 & 4.29 & -1.13 & -26.3 \\
\hline & & 30.58 & 27.32 & +3.26 & +11.9 \\
\hline & & $\ldots$ & 2.27 & -2.27 & -100.0 \\
\hline & & $\cdots$ & 1.02 & -1.02 & -100.0 \\
\hline & & 1.90 & 2.27 & -0.37 & -16.3 \\
\hline & & 39.62 & 39.62 & \pm 4.79 & 上 12.1 \\
\hline \multirow{5}{*}{$\begin{array}{l}\text { Drum } 65769 \\
\text { IDC } 480 \\
\text { Metal } \\
\text { Number of hags } \\
\text { not de,ermined }\end{array}$} & \multirow{5}{*}{$\begin{array}{l}\text { Cellulosic } \\
\text { Plastic } \\
\text { Corr. Metal/Steel } \\
\text { Non-Corr. Metal }\end{array}$} & Not esti- & 2.17 & & \\
\hline & & mated due & 8.32 & & \\
\hline & & to contami- & 131.77 & & \\
\hline & & & $1,1,16$ & & \\
\hline & & & 143.28 & & \\
\hline \multirow{7}{*}{$\begin{array}{l}\text { Drum } 65988 \\
\text { IDC } 480 \\
\text { Metal } \\
5 \text { Bags }\end{array}$} & \multirow{7}{*}{$\begin{array}{l}\text { Cellulosic } \\
\text { Plastic } \\
\text { Corr. Metal/Steel } \\
\text { Corr. Metal/Al } \\
\text { Cement } \\
\text { Unknown }\end{array}$} & 2.17 & 2.17 & & 0.0 \\
\hline & & 10.90 & 9.52 & +1.38 & +14.5 \\
\hline & & 7.30 & 10.79 & -3.49 & +32.3 \\
\hline & & 1.80 & 0.91 & +0.95 & +104.4 \\
\hline & & - & 0.4 .5 & -0.45 & -100.0 \\
\hline & & 1.61 & $\cdots$ & +1.61 & $\ldots$ \\
\hline & & 23.84 & 23.84 & \pm 3.94 & \pm 16.5 \\
\hline \multirow{8}{*}{$\begin{array}{c}\text { Average Values } \\
\text { Drums } 63389 \\
\text { and } 65988\end{array}$} & \multirow{8}{*}{$\begin{array}{l}\text { Cellulosic } \\
\text { Plastic } \\
\text { Corr. Metal/Steel } \\
\text { Corr. Metal/Al } \\
\text { Non-Corr. Matal } \\
\text { Cement } \\
\text { Unknown }\end{array}$} & 3.08 & 2.31 & +0.77 & +32.5 \\
\hline & & 7.0 .3 & 6.90 & +0.13 & +1.9 \\
\hline & & 18.94 & 19.06 & -0.12 & -0.6 \\
\hline & & 0.93 & 1.50 & -0.66 & --41.5 \\
\hline & & $\cdots$ & 0.51 & $\cdots 0.51$ & -100.0 \\
\hline & & 0.95 & 1.36 & $\cdots 0.41$ & -30.1 \\
\hline & & 0.80 & $\cdots$ & +0.80 & $\begin{array}{r}+0.0 \\
-\end{array}$ \\
\hline & & .31 .73 & 31.73 & \pm 1.70 & \pm 5.3 \\
\hline
\end{tabular}

respectively. Considering that sement is a moderate gas generator and represents $4.7 \%$ of the waste, visual inspection may be an acceptable characterization method for cement in metal waste.

If one assumes, based on the detection assessment, that visual inspection is a viable method for characterization, then the accuracy and precision should be evaluated. As shown in Table 2, the mean for corroding metal/steel is $+10 \%$, and the standard deviation is $43 \%$. This means that the estimated values, on the average, are $10 \%$ high and that the error bar at $95 \%$ confidence (two standard deviations) is $86 \%$. While these data indicate a low level of precision, a problem is evident when the other component materials are addressed. Visual estimates for plastic have both a large mean $(-260 \%)$ and standard deviation $(563 \%)$. For cellulosics and corroding metal/ aluminum, there are insufficient data even to calculate: standard deviation. Use of visual inspection in weighing segregated material in the actual waste will not provide a practical method of operator training. This premise is based on: the number of operators to be certified, the number of data points for statistical evaluation of each 
operator, and the fact that only a iew packages per drum contain cellulosics and aluminum.

Presented in Table 4 are the visual inspection and physical examination dat a compiled on a drum basis. The proportions of material incorrectly identified by visual inspection within the two drurns of metal waste were 16.0 and $18.8 \%$. Howsver, if one examines the data on specific waste materials, the percentage error is quite large. Also, it should be recognized that when the data are compiled on a drum basis, some plus-andminus values cancel each other. The precision and accuracy must be addressed on the basis of bag estimates: therefore, the drum data may be somewhat misleading.

One drum contained contamination outside the individual packages, and a second drum contained six bags with exterior contamination. Because of th. contamination, visual inspection must be done in the vault by people in supplied-air suits with air supply hoods, rather than in the air lock with fullface respiratory protection. Recognizing that some percentage of any waste (not just metal) may have exterior package contamination, visual inspection, if used, must be performed inside a vault or glor ebox

Establishing a database for visual inspection would require visual inspection and physical examination of many drums, probably far exceeding the number required for the bin-scale tests. Using the average data for the two drums visually inspected, the estimating error for cellulosic, steel, and aluminum (all high gas generators) was less than $50 \%$. Therefore, visual characterization may be an acceptable method if simulated waste packages can be used for training and establishing method accuracy.

The RTR inspection was not used to estimate weight composition of TRUCON Code 117 waste because of the limited ability of RTR to distinguish among steel, copper, and aluminum in drums filled with various sizes and shapes of metal. The RTR inspection was used to confirm the WIPP criteria and provide review information for operators performing visual inspection.
Physical examination of metal waste (IDC 480) presents two problems: There is a safety concern with cutting tape to expose the matal, and removing the tape is tedious and labor-intensive. RTR inspection of the waste drum does not provide a good basis for identifying material to aid visual inspection because of interference of various rackages within the drum. What does app zar to be reasonable is utilizing a package RTR ( $\mathrm{fr} r$ individual packages, not drums) to help identify metal type and images of individual metal items. The metal shape and an outline of the plastic or cellulosic around the metal item may provide information to support visual inspection. Also, RTR of a single metal item may be able to detect the type of meial or discriminate among certain types, such as aluminum versus steel.

If package R'TP coldd be tested, evaluated, and installed, it together with visual inspection may well be acceptable for characterizing this category of waste. It may be possible to accomplish the training with visual/package RTR inspection using simulated waste. However, the system of characterization may still have to be verified during the bin-scale tests with actual waste. It is therefore assumed that physical examination will be needed during loading of the bins for this type waste.

\section{TRUCON Code 118, Glass Waste (IDC 440, 442, 368)}

Four drums were selected for examination: one IDC 440 (glass--non-Raschig rings), two IDC 442 (Raschig rings), and one IDC 368 (magnesium oxide crucibles). Each drum was subjected to characterization by RTR inspection, visual inspection, and physical examination.

The four drums contained 51 bags, which were subjected to visual inspection and physical examination by segregating and weigt:ing component materials. As indicated in Table 1, all the materials are low gas generators except inorganic sludge. which is listed as a moderate gas generator due to radiolysis. However, corganic sludge was present in only one bag (IDC 44.2, Drum 59624) and represents less than $1 \%$ of the total waste 
examined in this TRUCON Code. The inorganic sludge was not detected by visual inspection.

The NDI and WDI were good for plastic and noncorroding metal. The non-corroding metal was lead tape on some of the bottles in laboratory glass (IDC 440, Drum 60463). The lower detection index $(\mathrm{NDI}=76 \%$ and $\mathrm{WDI}=86 \%)$ is primarily a result of poor detectability in the magnesium oxide crucibles (IDC 368, Drum 62165). This drum contained opaque plastic containers in each bag, which prevented visual identification of the contents without opening the bags. The statistical data, mean and standard deviation, for the visual inspection are presented in Table 2 . These results are good for solid inorganic but inferior or insufficient for other material types.

The visual, physical, and RTR characterization results for each drum examined are presented in Table 5. Also presented is the calculated average for the four drums. The RTR inspection did not detect the lead tape contained in Drum 60463. However, the quantity present is small and the visual inspections that did detect the lead did not produce highly accurate estimates. Neither the visual or RTR inspection detected the small amount of inorganic sludge in Drum 59624. 'The major difference in the RTR and visual inspection occurred with the drum of magnesium oxide crucibles (Druri 62165). The visual listed $25.5 \mathrm{~kg}$ $(66.5 \%)$ of the total $38.5 \mathrm{~kg}$ of waste as unknown. The RTR inspection resulted in correctly identifying the crucible material within a small error of $5.7 \%$ for IDC 368 waste.

\section{TRUCON Code 119 , HEPA Filter Waste (IDC 342)}

Two drums of HEPA filters were selected for characterization testing by RTR, visual, and physical inspection methods. These drums contained small glovebox filters. Drums containing filter media or cemented media were not examined due to limitatic 1 on assay capabilities for repacked mixed waste.
Eleven individual packages were contained in each of these drums. For each examination method, standard weights were used to convert the weight of the given filter size to a weight for: cellulosic (wood frame), corroding metal/Al (separators), solid inorganic (filter media), and rubber (gaskets). For visu ' inspection and physical examination, the used filters sometimes weighed more or less than the standard weight. If a filter weighed more thain the standard, the additional weight was ass!med to be collerted dust (solid inorganic). If a filter weighed less than the standard, the recorded weight for cellulosic was decreased because weight of the wood frame was assumed to vary more than the other components. The amount of rubber and corroding metal/aluminum estimated by visual inspection and physical examination were identical for each filter due to the method of applying the standard weights.

The cellulosic and corroding metal/aluminum are listed (Table 1) as high gas generators and represent 60.4 and $8.4 \%$, respectively, of the mixture. All other component materials exhibit low gas generation potential. The NDI and WDI by visual inspection for all waste components were good $(90$ to $100 \%$ ). Presented in Table 2 are statistical results for vistal inspection characterization. For the high gas generators (cellulosic and aluminum), the mean and standard derivations are quite good. Based on this inf crmation, one could assume the visual inspection characterization method is acceptable.

Presented in Table 6 are results from RTR inspection, visual inspection, an I physical examination data calculated for each, and an average calculation for the two drums. Based on the average of the two drums, the RTR estimate for cellulosic is comparable with the visual estimate. The RTR inspection resulted in a $4.5 \%$ error for aluminum compared to $0 \%$ for visual. The total misidenti. fied by RTR was $11 \%$; for visual, it was only $4.1 \%$. Both RTR and visual methods produced acceptable results. Because of less radiation exposure and lower manpower requirements, the RTR method of characterization is preferred. 
TABLE 5. Visual, RTR, and Physical Characterization Results for Trucon Coce 118 Waste

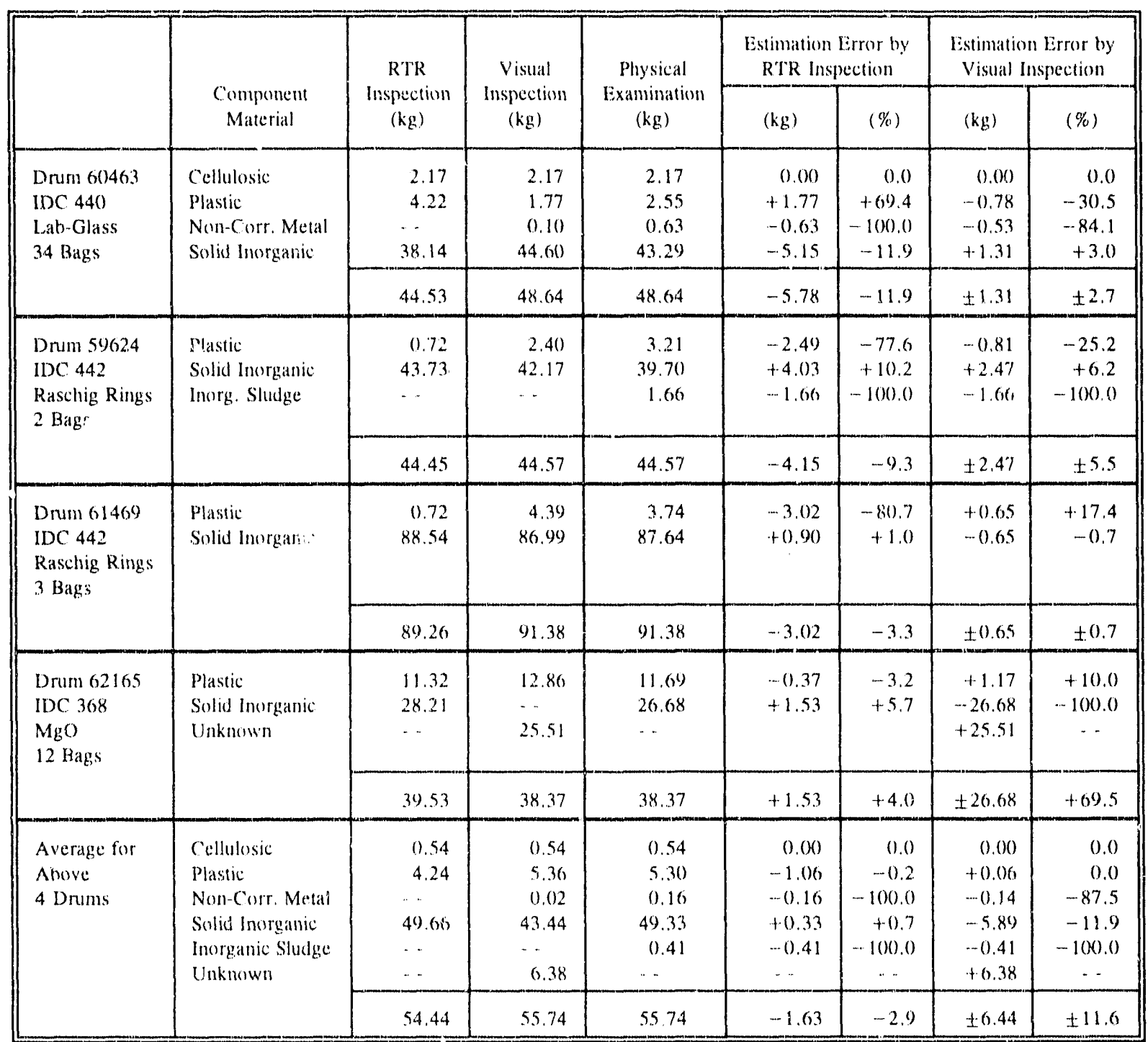

TRUCON Code 122,

Inorganic Selid Waste (IDC 438)

Two drums of insulation waste were subjected to characterization tests by RTR inspection, visual ins r.ction, and physical examination. One drum contained a single bag, and the other contained four individual packages.

All materials present in the insulation examined are classified as having low gas generation potential (Table 1). The non-corroding metal is the only category with poor number and weight detection values $(\mathrm{NDI}=-50 \%, \mathrm{WDI}=2 \%)$.
Even with the low level of detectability for noncorroding metal (which represents $5.7 \%$ of the waste), the net result on gas generation may be small because the components are low gas generators. The statistical data for visual inspection of insulation waste are presented in Table 2.

Results of the RTR inspection characterization are presented in Table 7 for comparison with the visual and physical characterization data on a drum-by-drum basis. Also included are averaged values for the two drums. For Drum 65733, the RTR results were better than the visual inspection 
TABLE 6. Visual, RTR, and Physical Characterization Results for Trucon Code 119 Waste

\begin{tabular}{|c|c|c|c|c|c|c|c|c|}
\hline & \multirow{2}{*}{$\begin{array}{l}\text { Component } \\
\text { Material }\end{array}$} & \multirow{2}{*}{$\begin{array}{c}\text { R'TR } \\
\text { Inspection } \\
\text { (kg) }\end{array}$} & \multirow{2}{*}{$\begin{array}{c}\text { Visual } \\
\text { Inspection } \\
(\mathrm{kg})\end{array}$} & \multirow{2}{*}{$\begin{array}{c}\text { Physical } \\
\text { Examination } \\
(\mathrm{kg})\end{array}$} & \multicolumn{2}{|c|}{$\begin{array}{c}\text { Estimation Error by } \\
\text { RTR Inspection }\end{array}$} & \multicolumn{2}{|c|}{$\begin{array}{c}\text { Estimation Error by } \\
\text { Visual Inspection }\end{array}$} \\
\hline & & & & & $(\mathrm{kg})$ & $(\%)$ & $(\mathrm{kg})$ & $(\%)$ \\
\hline \multirow{7}{*}{$\begin{array}{l}\text { Drum } 70852 \\
\text { IDC } 342 \\
\text { HEPA Filters } \\
11 \text { Bags }\end{array}$} & \multirow{7}{*}{$\begin{array}{l}\text { Cellulosic } \\
\text { Plastic } \\
\text { Rubber } \\
\text { Corr. Metal/Steel } \\
\text { Corr. Metal/Al } \\
\text { Solid Inorganic }\end{array}$} & $16.6 ?$ & 18.21 & 17.83 & -1.21 & $\cdots 6.7$ & +0.48 & +2.7 \\
\hline & & 6.24 & 4,91 & 5.73 & +0.51 & +8.9 & -0.82 & -14.3 \\
\hline & & 0.62 & 0.33 & 0.33 & +0.29 & +87.9 & 0.00 & 0.0 \\
\hline & & 1.60 & $\cdots$ & $\cdots$ & +1.60 & $\cdots$ & $\ldots$ & $\ldots$ \\
\hline & & 1.80 & 2.20 & 2.20 & +0.40 & +18.2 & 0.00 & 0.0 \\
\hline & & 0.65 & 2.74 & 2.30 & -1.65 & -71.7 & +0.44 & +19.1 \\
\hline & & 27.53 & 28.39 & 28.39 & -2.80 & -10.1 & \pm 0.82 & \pm 2.9 \\
\hline \multirow{8}{*}{$\begin{array}{l}\text { Drum } 62162 \\
\text { IDC } 342 \\
\text { HEPA Filters } \\
11 \text { Bags }\end{array}$} & \multirow{8}{*}{$\begin{array}{l}\text { Cellulosic } \\
\text { Plastic } \\
\text { Rubber } \\
\text { Corr. Metal/Steel } \\
\text { Corr. Metal/Al } \\
\text { Solid Inorganic } \\
\text { Other Organic }\end{array}$} & 18.46 & 16.76 & 16.04 & +2.42 & +15.1 & +0.72 & +4.5 \\
\hline & & 2.64 & 4.87 & 5.97 & -3.33 & $-55,8$ & -1.10 & -18.4 \\
\hline & & 0.41 & 0.33 & 0.33 & +0.08 & +24.2 & 0.00 & 0.0 \\
\hline & & 0.75 & $\cdots$ & - & +0.75 & $\ldots$ & $\cdots$ & $\ldots$ \\
\hline & & 2.40 & 2.20 & 2.20 & +0.20 & +9.1 & 0.00 & 0.0 \\
\hline & & 0.87 & 2.04 & 1.28 & -0.41 & -32.0 & +0.76 & +.59 .4 \\
\hline & & $\cdots$ & 1.29 & 1.67 & -1.29 & -77.2 & -0.38 & -22.8 \\
\hline & & 25.53 & 27,49 & 27.49 & +5.03 & +18.3 & \pm 1.48 & \pm 5.4 \\
\hline \multirow{8}{*}{$\begin{array}{l}\text { Average for } \\
\text { Above } \\
2 \text { Drums }\end{array}$} & \multirow{8}{*}{$\begin{array}{l}\text { Cellulosic } \\
\text { Plastic } \\
\text { Rubber } \\
\text { Corr. Metal/Steel } \\
\text { Corr. Metal/A. } \\
\text { Solid Inorganic } \\
\text { Other Organic }\end{array}$} & 17.54 & 17.48 & 16.03 & +0.61 & +36 & +0.55 & +3.2 \\
\hline & & 4.44 & 4.89 & 5.85 & -1.41 & -24.1 & -0.96 & --16.4 \\
\hline & & 0.52 & 0.33 & 0.33 & +0.19 & +57.6 & 0.00 & 0.0 \\
\hline & & 1.17 & $\cdots$ & $\cdots$ & +1.17 & . - & $\ldots$ & $\cdots$ \\
\hline & & 2.10 & 2.20 & 2.20 & -0.10 & -4.5 & 0.0() & 0.0 \\
\hline & & 0.76 & 2.39 & 1.79 & -1.03 & -57.5 & +0.60 & +33.5 \\
\hline & & 0.32 & 0.65 & 0.84 & -0.52 & -61.9 & -0.19 & -22.6 \\
\hline & & 26.85 & 27.94 & 27.94 & -3.06 & -11.0 & \pm 1.15 & \pm 4.1 \\
\hline
\end{tabular}

results: for Drum 70851, the visual inspection results were better. However, for the average of the two drums, the two methods were nearly equal. Again, because of lower radiation exposure and lower labor requirements, the RTR characterization method :s preferred.

\section{TRUCON Code 123, Leaded Rubber Waste (IDC 339)}

One drum of rubber waste was selected for characterization by RTR inspection, visual inspection, and physical examinaiion. While only one drum was examined, it is expected to be a good indication of this waste category because it is relatively uniform waste. Each characterization method estimated the amount of leaded rubber, and a calculation based on standard composition weights was used to determine the rubber and solid inorganic.

The drum contained 11 individual packages, which were visually inspected. Inspection from outside the bags failed to reveal any material other than leaded rubber. Because the rubber is opaque, the operators did not observe the cellulosic in one package. The operators did not list plastic (even though it was evident) as the bag containing the waste. This failure to list plastic could be corrected by better instruction or training. It should be listed, even though its weight is small compared to the bag contents.

As shown in Table 1, the detection indexes for cellulosic and plastic were $0 \%$. The ce lulosic, which represented $2.4 \%$ of the waste, is the only niaterial listed as high for gas generation potential. 
TABLE 7. Visual, RTR, and Physical Characterization Results for Trucon Code 122 Waste

\begin{tabular}{|c|c|c|c|c|c|c|c|c|}
\hline & \multirow{2}{*}{$\begin{array}{l}\text { Component } \\
\text { Material }\end{array}$} & \multirow{2}{*}{$\begin{array}{c}\text { RTR } \\
\text { Inspection } \\
\text { (kg) }\end{array}$} & \multirow{2}{*}{$\begin{array}{c}\text { Visual } \\
\text { Inspection } \\
(\mathrm{kg})\end{array}$} & \multirow{2}{*}{$\begin{array}{c}\text { Physical } \\
\text { Examination } \\
(\mathrm{kg})\end{array}$} & \multicolumn{2}{|c|}{$\begin{array}{l}\text { Estimation Error by } \\
\text { RTR Inspection }\end{array}$} & \multicolumn{2}{|c|}{$\begin{array}{l}\text { Estimation Error by } \\
\text { Vistual Inspection }\end{array}$} \\
\hline & & & & & $(\mathrm{kg})$ & $(\%)$ & $(\mathrm{kg})$ & (\%) \\
\hline \multirow[t]{2}{*}{$\begin{array}{l}\text { Drum } 6.5733 \\
\text { IDC } 438 \\
\text { Insulation } \\
1 \text { Bag }\end{array}$} & \multirow[t]{2}{*}{$\begin{array}{l}\text { Cellulosic } \\
\text { Plastic } \\
\text { Non-Corr. Metal } \\
\text { Solid Inorganic }\end{array}$} & $\begin{array}{l}2.17 \\
0.72 \\
4.00 \\
8.14\end{array}$ & $\begin{array}{l}2.17 \\
0.72 \\
- \\
11.25\end{array}$ & $\begin{array}{l}2.17 \\
0.72 \\
2.72 \\
8.53\end{array}$ & $\begin{array}{r}0.00 \\
0.00 \\
+1.28 \\
-0.39\end{array}$ & $\begin{array}{r}0.0 \\
0.0 \\
+47.1 \\
-4.6\end{array}$ & $\begin{array}{r}0.00 \\
0.00 \\
-2.72 \\
+2.72 \\
\end{array}$ & $\begin{array}{r}0.0 \\
0.0 \\
-100 \\
+31.9\end{array}$ \\
\hline & & 15.03 & 14.14 & 14.14 & +1.28 & +9.1 & \pm 2.72 & \pm 19.2 \\
\hline \multirow[t]{2}{*}{$\begin{array}{l}\text { Drum } 708.51 \\
\text { IDC } 438 \\
\text { Insulation } \\
4 \text { Bags }\end{array}$} & \multirow[t]{2}{*}{$\begin{array}{l}\text { Cellulosic } \\
\text { Plastic } \\
\text { Corr. Metal/Steel } \\
\text { Corr. Metal/Al } \\
\text { Non-Corr. Metal } \\
\text { Solid Inorganic }\end{array}$} & $\begin{array}{l}\cdots \\
0.72 \\
0.80 \\
1.40 \\
\cdots \\
35.64\end{array}$ & $\begin{array}{l}1.56 \\
1.85 \\
- \\
\cdots \\
0.25 \\
36.40 \\
\end{array}$ & $\begin{array}{l}\cdots \\
2.73 \\
\cdots \\
- \\
0.15 \\
37.18\end{array}$ & $\begin{array}{l}-2.01 \\
+0.80 \\
+1.40 \\
-0.15 \\
-1.54 \\
\end{array}$ & $\begin{array}{c}\cdots \\
-73,6 \\
\cdots \\
-- \\
-100.0 \\
-4.1 \\
\end{array}$ & $\begin{array}{l}+1.56 \\
-0.88 \\
-- \\
- \\
+0.10 \\
-0.78\end{array}$ & $\begin{array}{c}\cdots \\
-32.2 \\
\cdots \\
- \\
+66.7 \\
-2.1\end{array}$ \\
\hline & & 38.56 & 40.06 & 40.06 & -3.70 & $-9,2$ & \pm 1.66 & \pm 4.1 \\
\hline \multirow[t]{2}{*}{$\begin{array}{l}\text { Average for } \\
\text { Above } \\
2 \text { Drums }\end{array}$} & \multirow[t]{2}{*}{$\begin{array}{l}\text { Cellulosic } \\
\text { Plastic } \\
\text { Corr. Metal/Steel } \\
\text { Corr. Metal/Al } \\
\text { Non-Corr. Metal } \\
\text { Solid Inorganic }\end{array}$} & $\begin{array}{r}1.08 \\
0.72 \\
0.40 \\
0.70 \\
2.00 \\
21.89\end{array}$ & $\begin{array}{l}1.87 \\
1.28 \\
- \\
- \\
0.12 \\
23.83\end{array}$ & $\begin{array}{l}1.08 \\
1.72 \\
\cdots \\
- \\
1.44 \\
22.86\end{array}$ & $\begin{array}{r}0.00 \\
-1.00 \\
+0.40 \\
+0.70 \\
+0.56 \\
-0.97\end{array}$ & $\begin{array}{r}0.0 \\
-58.1 \\
- \\
- \\
+38.9 \\
-4.2\end{array}$ & $\begin{array}{l}+0.79 \\
-0.44 \\
\cdots \\
-1.32 \\
+0.97\end{array}$ & $\begin{array}{c}+73.1 \\
-25.6 \\
-- \\
-- \\
-91.7 \\
+4.2\end{array}$ \\
\hline & & 26.79 & 27.10 & 27.10 & -1.97 & -7.3 & \pm 1.76 & \pm 6.5 \\
\hline
\end{tabular}

Statistical data for this waste are presented in Table 2. For this category of waste (IDC 339), the error of estimating by visual and RTR was only a reflection of how well the waste was segregated as originally packaged. This was because neither method detected any components that were within the rubber. Therefore, statistical data on the waste minor components within this category would be the same as the best estimate of the other materials. RTR and visual inspection provided no additional information on the presence of trace components.

The RTR characterizarion data are presented in Table 8 with the visual and physical data for the drum of leaded rubber. Both RTR and visual inspection failed to detect the cellulosics.

Accuracy of the R'TR is almost as good as that from visual inspection. In fact, the only difference is introduced by subtracting the standard weights for the drum and rigid liner from the gross weight of the drum. The accuracy should improve by using more accurate standard weights for packaging components. The RTR inspection method for characterizing rubber waste is preferred because of less labor required and lower radiation exposure to personnel.

\section{TRUCON CODE 115, Graphite Waste (IIDC 300)}

One drum of graphite was subjected to characterization by physical examination, and the data are presented in Table 9. The drum contained four packages weighing 11 to $17 \mathrm{~kg}$. Because of weight of the bags and sharp edges of the graphite, visual inspection from outside the bags was determined inappropriate for work in the air lock. If visual inspection were to be performed, considerable movernent of graphite in the bag would be required to detect any other material present. Opening the bags in the vault and weighing the 
TABLE 8. Visual, RTR, and Physical Characterization Results for Trucon Code 123 Waste

\begin{tabular}{|c|c|c|c|c|c|c|c|c|}
\hline & \multirow{2}{*}{$\begin{array}{l}\text { Component } \\
\text { Material }\end{array}$} & \multirow{2}{*}{$\begin{array}{c}\text { RTR } \\
\text { Inspection } \\
(\mathrm{kg})\end{array}$} & \multirow{2}{*}{$\begin{array}{l}\text { Visual } \\
\text { Inspection } \\
(\mathrm{kg})\end{array}$} & \multirow{2}{*}{$\begin{array}{c}\text { Physical } \\
\text { Examination } \\
\quad(\mathrm{kg})\end{array}$} & \multicolumn{2}{|c|}{$\begin{array}{l}\text { Estimation Error by } \\
\text { RTR Inspection }\end{array}$} & \multicolumn{2}{|c|}{$\begin{array}{l}\text { Estimation Error by } \\
\text { Visual Inspection }\end{array}$} \\
\hline & & & & & (kg) & $(\%)$ & (kg) & $(\%)$ \\
\hline \multirow{5}{*}{$\begin{array}{l}\text { Drum } 69991 \\
\text { IDC } 339 \\
\text { I eaded Gloves } \\
11 \text { Bags }\end{array}$} & \multirow{5}{*}{$\begin{array}{l}\text { Cellulusic } \\
\text { Plastic } \\
\text { Rubber } \\
\text { Solid Inorganic }\end{array}$} & - & $\cdots$ & 1.25 & -1.25 & -100.0 & -1.25 & -100.0 \\
\hline & & 0.72 & 0.7 & 5.51 & -4.79 & -86.9 & -4.79 & -86.9 \\
\hline & & 19.94 & 19.65 & 17.41 & +2.53 & +14.5 & +2.24 & +12.9 \\
\hline & & 33.90 & 33.27 & 29.47 & $\begin{array}{r}+4.43 \\
\end{array}$ & $\begin{array}{r}+15.0 \\
\end{array}$ & $\begin{array}{r}+3.80 \\
\end{array}$ & $\begin{array}{r}+12.9 \\
\end{array}$ \\
\hline & & 54.53 & 53.64 & 53.64 & +6.96 & +13.0 & \pm 6.04 & \pm 11.3 \\
\hline
\end{tabular}

TABLE 9. Visual, R'TR, and Physical Characterization Results for Trucon Code 115 Waste

\begin{tabular}{|c|c|c|c|c|c|}
\hline & \multirow{2}{*}{$\begin{array}{l}\text { Compqonent } \\
\text { Material }\end{array}$} & \multirow{2}{*}{$\begin{array}{c}\text { RTR } \\
\text { Inspection } \\
\text { (kg) }\end{array}$} & \multirow{2}{*}{$\begin{array}{l}\text { Physical } \\
\text { Examination } \\
(\mathrm{kg})\end{array}$} & \multicolumn{2}{|c|}{$\begin{array}{c}\text { Estimation Error by } \\
\text { RTR Inspection }\end{array}$} \\
\hline & & & & $(\mathrm{kg})$ & $(\%)$ \\
\hline \multirow{2}{*}{$\begin{array}{l}\text { Drum } 69399 \\
\text { IDC } 330 \\
\text { Graplite } \\
4+\text { Bags }\end{array}$} & \multirow[t]{2}{*}{$\begin{array}{l}\text { Cellulosic } \\
\text { Plastic } \\
\text { Solid Inorganic }\end{array}$} & $\begin{array}{r}2.17 \\
0.72 \\
59.44\end{array}$ & $\begin{array}{r}2.17 \\
0.72 \\
55.44\end{array}$ & $\begin{array}{r}0.00 \\
0 .(10) \\
+4.00\end{array}$ & $\begin{array}{r}(1.00 \\
0.00 \\
+7.2\end{array}$ \\
\hline & & 62.33 & 60.87 & +4.0() & +6.6 \\
\hline
\end{tabular}

components or using a standard weight for the bags would appear to be less time-consuming than the visual inspection.

The RTR characterization data are also presented in Table 9. The RTR inspection produced a $7.2 \%$ error for solid inorganic (graphite) or $6.6 \%$ error based on waste content of the entire drum. All errors in this characterization resulted from inaccurate gross drum weights or the standard weights for packaging materials. The RTR inspection appears to be acceptable for characterizing graphite waste, even thrugh only one drum was examined. These results should be somewhat representative because this category is anticipated to be well segregated from other waste materials.

\section{Headspace Gas Analysis}

Analytical results of headspace gas samples from 12 of the drums are presented in Table 10. The hydrogen concentration exceeded $1 \%$ in two drums: Drum 67988 (wet combustibles) and Drum 63389 (light metal). These concentrations are significantly below the flammability limits. The metal waste (Drum 63389) also contained a trace of methane and other unidentified organic compounds. If these hydrogen concentrations are representative of what could be expected for the types of waste tested, flammability should not be a significant problem. However, if one has to show individual bags do not contain flammable mixtures, the effect of multiple layers of bags could cause elevated hydrogen concentrations within the inner bags.

Of the drums tested, only very minor amounts of hazardous chlorinated compounds were detected. Drum 67771 (dry combustibles) contained a trace of dichloromethane, and Drum 63389 (light metal) contained $0.2 \%$ carbon tetrachloride and $500 \mathrm{ppm}$ trichloromethane. Other organics were also identified. The data suggest that these waste types 
TABLE 10. Headspace Gas Analysis

\begin{tabular}{|c|c|c|c|c|c|c|c|c|c|c|c|}
\hline \multirow[b]{2}{*}{ Drum } & \multirow[b]{2}{*}{ IDC } & \multirow[b]{2}{*}{ Description } & \multirow{2}{*}{$\begin{array}{c}\text { Drum Pu } \\
\text { Content } \\
\text { (g) }\end{array}$} & & \multicolumn{7}{|c|}{ Gas Composition ( $\mathrm{Vol}_{\mathrm{ol}} \%$ ) } \\
\hline & & & & $\mathrm{H}_{2}$ & $\mathrm{~N}_{2}$ & $\mathrm{CO}$ & $\mathrm{O}_{2}$ & $\mathrm{NO}_{x}$ & $\mathrm{CO}_{2}$ & $\mathrm{CCl}_{4}$ & Other \\
\hline 67771 & Q31 & Dry Comb. & 2 & 0.1 & 79.2 & $\cdots$ & 2.6 & $\cdots$ & 17.2 & $\cdots$ & (1) \\
\hline 69645 & 831 & Dry Comb. & 1 & $\cdots$ & 79.0 & $\cdots$ & 10.6 & $-\cdots$ & 9.5 & $\cdots$ & $\cdots$ \\
\hline 60742 & 832 & Wet Comb. & 16 & 0.6 & 87.5 & - & 7.6 & $\cdots$ & 3.4 & $\cdots$ & $\cdots$ \\
\hline 67988 & 832 & Wet Comb. & 2 & 1.1 & 79.3 & $\ldots$ & 17,9 & Trace & 0.8 & $\cdots$ & $\cdots$ \\
\hline 69869 & 832 & Wet Comb. & 18 & Trace & 79.8 & $\cdots$ & 16.8 & 0.6 & 1.9 & $\cdots$ & $\ldots$ \\
\hline 70260 & 833 & Plastic & 1 & Trace & 77.9 & 0.6 & 16.0 & - & 4.6 & $\cdots$ & $\cdots$ \\
\hline 63389 & 480 & Metal & 0 & 1.2 & 81.7 & 0.2 & 13.8 & $\cdots$ & 2.0 & 0.2 & (2) \\
\hline 65769 & 480 & Metal & 5 & $\cdots$ & $\cdots$ & - & $\cdots$ & $\cdots$ & $\therefore$ & $\cdots$ & (3) \\
\hline 65988 & 480 & Metal & 3 & Trace & 76.5 & 0.9 & 9.4 & 1.2 & 11.1 & $\cdots$ & $\cdots$ \\
\hline 60463 & 440 & Glass & 8 & 0.2 & 78.1 & $\cdots$ & 20.5 & $\cdots$ & 0.3 & $\cdots$ & $\cdots$ \\
\hline 65733 & 438 & Insulation & 0 & $\cdots$ & 78.2 & $\cdots$ & 20.7 & 0.2 & $\cdots$ & $\cdots$ & - \\
\hline 69991 & 339 & Rubber & 14 & 0.1 & 79.8 & $\cdots$ & 18.7 & 0.1 & 0.4 & $\cdots$ & $\cdots$ \\
\hline
\end{tabular}

(1) T race Dichloromethane

(2) $500 \mathrm{ppm}$ 1,1,1-trichloroethane, trace of methane and other organics

(3) Nogas sample because of torn bag

should present few problems with respect to maximum headspace concentrations for hazardous constituents.

\section{Time Estimate of Waste Characterization/Test-Bin Loading}

In general, the operators can work up to 2.5 hours, in either the air lock or vault, two times during the normal eight-l ${ }^{\prime}$ )ur shift. The assessment of time required to perform the visual inspection and physical examination was based on how much waste was tested during each half of the shift. Therefore, the estimates include the time required for the operators to suit up and enter the air lock or vault. Because the tests were performed with actual waste, all the normal safety functions and procedures required for contamination control were integrated into the work performance and, therefore, the time data.
The time required to inspect a drum visually was influenced by several factors: number of bags, number of components within a bag, size of bag, and visibility of the waste within the bag. Time elapsing from opening a drum until all the bags were inspected ranged from 25 to 75 minutes. The average visual inspection was approximately 40 minutes. In addition, the time required to prepare the area, gather the proper people, and clean up the area was approximately two hours. Therefore, visually inspecting two or three drums is possible within a four-hour period.

Physical examination of a drum is approximately the same. However, the time required to get the operators in and out of the vault is greater.

Therefore, two drums in a four-hour period is a rigorous schedule. Completing visual inspection and physical examination of two drums in a single eight-hour shift is achievable for routine inspection operations. 
Because of current waste loading requirements within the vat.lt area, examined drums may have to be repackeo and stored outside the vault. Once enough drums have been inspected to fill a bin, the drums would be returned to the vault and the bin loaded. Taking into account all of the movement, storage, and packing requirements, an average of one bin loaded every two weeks is estimated. The rate may go to one bin per week once routine operation is established and if a second shift is impiemented in the vaut. This estimate does not take into acciount any holding time that may be required while samples are analyzed.

\section{Secondary Waste Generation from Inspection/Examination Activities}

The activities associated with waste characterization will generate secondary waste, such as plastic sheets, latex gloves, clothing, and suppliedair suits. The generation rate of the secondary waste is expected to relate directly to the number of times a crew is suited up to perform the function. It will also relate to the amount of waste characterized, depending on the throughput rate of inspection activities.

The amount of waste generated was recorded. Whether the secondary waste generated is mixed, low-level, or transuranic will be considered when assessing the potential impact on the bin-scale or Alcove program.

Waste generated during the visual examination of drums included a minimum of five sets of paper coveralls with hoods, and booties, plastic sheets, latex gloves, and miscellaneous plastic bags. This was low-level waste that must be placed in a drum and stored until it can be shipped to a permanent repository. The volume generated in one-half day of visual examination was approximately one-third drum. When the vault was closed, i.e., lunch or end of a shift, all the material was collected and placed in a waste receptacle. When work resumed, new plastic sheet material was used to cover the floor in the airlock. As explained earlier, this could total two or three drums visually inspected.
Waste generated during supplied-air operations within the vault was usually classified as low-level waste. This waste consisted of supplied-air suits, at leas two pair of surgeon's gloves per operator, sheets of plastic, and paper and cloth coveralls. The volume in a typical four-hour shift was approximately one-half drum. in a single shift, two drums may be examined, as explained earlier. After manual compaction, the volume of waste generated by both visual inspection and physical examination was approximately one-fourth cirum for each drum tested. However, if only physical examination is performed, the secondary waste generated will be reduced about $25 \%$.

\section{CONCLUSIONS}

1. Visual inspection of combustible waste (TRUCON Code 116) results in a low level of detection for cellulosics (39\% NDI, 7.4 WDI). Cellulosic represents about $25 \%$ of the waste and is a high gas generator. From the six drums examined, the low detection index for cellulosics leads to the conclusion that physical examination will be preferred if reasonably good characterization information is desired.

2. Visual inspection of light metal (TRUCON Code 117) will provide reasonably good detection, accuracy, and precision for corroding metal/steel. However, the detectability is not good for corroding metal/aluminum, which represents about $5 \%$ of the waste category and exhibits a high gas generation potential. Because of the limited number of packages containing aluminum, many packages or drums would have to be inspected to establish statistically significant data and credibility of visual inspection However, the use of simulated waste in: a training program could quantify the abinity of the operators to estimate waste composition without removing the bags or wrapping tape.

3. Because of the safety concerns and labor involved with cutting and removing tape from individual metal items, application of a package RTR should be evaluated as a charac- 
terization method for metal waste. It may be possible to detect the type of metal as well as the amount present in a concealed package using a package RTR.

4. The RTR inspection appears to provide sufficient information for adequate characterization of waste in TRUCON Codes 115 , $118,119,122$, and 123 . If RTR inspection is implemented, physical examinations will still be necessary during the bin loading to develop data to support accuracy of the RTR characterization method. Whenever RTR inspection indicates a high degree of uncertainty for any given drums, the waste could be subjected to physical examination even after the accuracy correlation has been established.

5. Where RTR inspection provides adequate characterization data, it should be utilized over visual inspection or physical examination because it requires less labor and minimizes radiation exposure to personnel.

6. The headspace gas analysis of the waste tested appears to indicate that the flammable mixture and the hazardous chemical concentrations should not be a problem for the large bag. It may be possible to find a flammable concentration of hydrogen in an individual bag if many layers of bags are present.

7. A single-shift operation in the vault, combined with other activities utilizing the vault, would result in a bin-loading rate of about one every two weeks. A bin-loading rate of one per week can be obtained if a second shift is utilized on the vault operations. Each of the rates could be considerably reduced if it becomes necessary to wait long periods for approval to load a bin based on gas sample analytical results.

8. The combination of visual inspection and physical t:xamination of drummed waste results in the seisondary waste (low level) generation rate of about $25 \%$. If only physical examination is required, the secondary waste generation rate will decrease.

\section{RECOMMENDATIONS}

1. Physical examination of TRUCON Code 116 , Combustibles, is recommended for characterizing material composition.

2. A training program utilizing simulated waste should be implemented to minimize unwrapping of metal waste during characterization of TRUCON Code 117 waste.

3. A package RTR should be evaluated as a tool for characterizing metal waste. It may provide an image suitable for detecting metal type, as well as a basis for estimating the amount of plastic or cellulosic relative to the metal. A package RTR could reduce the labor requirement and hazards associated with cutting and removing tape from individual items.

4. An RTR inspection should be used to generate material characterization data for TRUCON Codes $115,118,119,122$, and 123 waste. It will be necessary to perform physical examination to correlate accuracy of RTR characterization during bin loading. After loading bins in the bin-scale program, physical examination may be unnecessary except for drums where RTR inspection indicates a high degree of uncertainty.

5. If the capability for physical examination exists at a facility, visual inspection should be rejected as a characterization method unless all of the waste components can easily be seen through the bags. Physical examination provides better characterization data with less secondary waste generation.

\section{REFERENCES}

1. M. A. Molecke and A. R. Lappin, Test Plan Addendum 1: WIPP Bin-Scale CH TRU Waste Tests, SAND 90-2082, Sandia National Lab., Albuquerque, NM, December 1990).

2. Federal Register, 55, No. 220, 47700, November 14, 1990. 


\section{APPENDIX A}

\section{VISUAL INSPECTION/PHYSICAL EXAMINATION DATA}

TABLES A1 THROUGH A10 
RFP-4604 
TABLE A1. Cellulousic Material by Visual Inspection of Bags

\begin{tabular}{|c|c|c|c|c|c|c|c|c|c|}
\hline $\begin{array}{l}\text { Bag } \\
\text { No. }\end{array}$ & $\begin{array}{l}\text { Total } \\
(\mathrm{kg})\end{array}$ & $\begin{array}{c}\text { Estiriated } \\
(\mathrm{kg})\end{array}$ & $\begin{array}{c}\text { Actual } \\
(\mathrm{kg})\end{array}$ & $\begin{array}{c}\text { Difference } \\
(\mathrm{kg})\end{array}$ & $\begin{array}{l}\text { Bag } \\
\text { No. }\end{array}$ & $\begin{array}{l}\text { Total } \\
(\mathrm{kg}) \\
\end{array}$ & $\begin{array}{c}\text { Estimated } \\
(\mathrm{kg})\end{array}$ & $\begin{array}{c}\text { Actual } \\
(\mathrm{kg})\end{array}$ & $\begin{array}{c}\text { Difference } \\
(\mathrm{kg})\end{array}$ \\
\hline $1 D C 71$ & 32.63 & 0.00 & 17.66 & -17.66 & $9 W C 69$ & 1.02 & & & \\
\hline $1 D C 45$ & 20.65 & 0.00 & 11.58 & -11.58 & $10 w C 69$ & 0.93 & & & \\
\hline IWC42 & 1.33 & 0.100 & 0.4 .3 & -0.43 & 11 WC69 & 2.40 & & & \\
\hline $2 W C 42$ & 0.97 & & & & $12 W C 69$ & 3.52 & & & \\
\hline $3 W C 42$ & 1.04 & & & & 13 WC 69 & 0.86 & & & \\
\hline 4WC 42 & 2.21 & 0.00 & 0.30 & -0.30 & $14 W C 69$ & 0.24 & & & \\
\hline $5 W C 42$ & 3.75 & 0.00 & $0.5 \%$ & -0.57 & $15 W C 69$ & 0.47 & & & \\
\hline $6 \mathrm{WC42}$ & 2.96 & & & & $1 \mathrm{P} 60$ & 0.27 & & & \\
\hline $7 W C 42$ & 2.08 & & & & $2 \mathrm{P} 60$ & 2.90 & 2.60 & 2.38 & +0.22 \\
\hline $8 W C 42$ & 3.08 & & & & 3P60 & 0.69 & 0.04 & 0.05 & $\ldots 0.01$ \\
\hline $9 W C 42$ & 2.08 & 0.00 & 0.26 & -0.26 & $4 \mathrm{P}(0)$ & 0.22 & 0.11 & 0.11 & \\
\hline $10 \mathrm{WC4} 4$ & $1 .(x)$ & & & & $5 \mathrm{P} 60$ & 0.47 & & & \\
\hline $11 \times \mathrm{ve} 42$ & 1.31 & 0.00 & 0.11 & -0.11 & $6 \mathrm{P} 60^{\circ}$ & 1.20 & & & \\
\hline $12 W C 42$ & 0.62 & 0.61 & 0.23 & +0.38 & $7 p^{2}(6)$ & 0.90 & & & \\
\hline IWC8X & 4.40 & 000 & 0.01 & -0.01 & $8 P 60$ & 1.54 & 0.08 & 0.00 & +0.08 \\
\hline $2 W C 88$ & 3.23 & $(i,())$ & 2.77 & -2.77 & $9 \mathrm{p} 60$ & 0.32 & & & \\
\hline $3 W C 88$ & 4.69 & $0 \times 1$ & 1.36 & -1.36 & $10 P 60$ & 0.57 & 0.05 & 0.00 & $+0.0 s$ \\
\hline 4 wes & 1.24 & & & & $11 P(x)$ & 0.70 & & & \\
\hline $5 w C 88$ & 1.07 & & & & $12 P(0)$ & 0.43 & 0.41 & 0.06 & +0.35 \\
\hline OWCS8 & 26.76 & & & & $13 \mathrm{P} 60$ & 0.29 & 0.01 & 0.00 & +0.01 \\
\hline $1 \mathrm{WCO}$ & 208 & & & & $14 \mathrm{P} 60$ & 0.68 & & & \\
\hline $2 W(1)$ & $2.5 \mathrm{i}$ & & & & $15 \mathrm{P} 60$ & 0.21 & 0.20 & 0.05 & +0.15 \\
\hline $3 W C 09$ & 0.39 & & & & $10 \mathrm{PQO}$ & 0.38 & 0.04 & 0.11 & -0.07 \\
\hline $4 W(69$ & 205 & & & & $17 \mathrm{P} 60$ & 0.78 & 0.04 & $0 .(0)$ & +004 \\
\hline $5 x c 69$ & 245 & & & & $18 \mathrm{P} 60$ & 0.41 & & & \\
\hline obect & 0.35 & & & & $19 \mathrm{P} 60$ & 1.11 & & & \\
\hline $7 W 069$ & 1.49 & & & & $20 \mathrm{P} 60$ & 1.62 & & & \\
\hline rWC69 & 121 & & & & $21 \mathrm{P}^{2}(0)$ & 7.03 & $0 .(0)$ & 2.49 & -2.49 \\
\hline
\end{tabular}

Table $A 1$ continued on following page 
TABLE A!. Cellulosic Material by Visual Inspection of Bags (Continued)

\begin{tabular}{|c|c|c|c|c|c|c|c|c|c|}
\hline $\begin{array}{l}\text { Bag } \\
\text { No. }\end{array}$ & $\begin{array}{l}\text { Total } \\
(\mathrm{kg})\end{array}$ & $\begin{array}{c}\text { Estimated } \\
(\mathrm{kg})\end{array}$ & $\begin{array}{c}\text { Actual } \\
(\mathrm{kg})\end{array}$ & $\begin{array}{c}\text { Difference } \\
(\mathrm{kg})\end{array}$ & $\begin{array}{l}\text { Bag } \\
\text { No. }\end{array}$ & $\begin{array}{l}\text { Total } \\
(\mathrm{kg})\end{array}$ & $\begin{array}{l}\text { Estimated } \\
\qquad(\mathrm{kg})\end{array}$ & $\begin{array}{c}\text { Actual } \\
(\mathrm{kg})\end{array}$ & $\begin{array}{l}\text { Difference } \\
(\mathrm{kg})\end{array}$ \\
\hline $1 \mathrm{M} 89$ & 1.44 & & & & $11 G \mathrm{GL} 63$ & 1.93 & & & \\
\hline $2 \mathrm{M} 89$ & 2.01 & 1.81 & 0.28 & +1.53 & 12GLG? & 1.47 & & & \\
\hline $3 \mathrm{M} 89$ & 5.80 & & & & 13GL.63 & 0.45 & & & \\
\hline $4 \mathrm{M} 89$ & 10.36 & & & & 14 GL6 63 & 1.36 & & & \\
\hline $5 \mathrm{M} 89$ & 1.13 & & & & $15 \mathrm{GL} 6 ?$ & 0.23 & & & \\
\hline $6 \mathrm{M} 89$ & 7.60 & & & & $16 \mathrm{GL}, 6,3$ & 0.46 & & & \\
\hline $7 \mathrm{M} 89$ & 5.05 & & & & 17GL.63 & 1.25 & & & \\
\hline $8 \mathrm{M} 89$ & 1.1 .3 & & & & $18 \mathrm{GL} 63$ & 0.68 & & & \\
\hline $9 \mathrm{M} 89$ & 0.23 & $\mathrm{NE}$ & & & $19 \mathrm{GL} 63$ & 1.36 & & & \\
\hline $10 \mathrm{M} 89$ & 0.91 & $\mathrm{NE}$ & & & $20 \mathrm{Gi} .6 .3$ & 4.99 & & & \\
\hline 11989 & 0.2 .3 & NI: & & & $21 \mathrm{GL} 63$ & 0.68 & & & \\
\hline $12 \mathrm{MBg}$ & 0.34 & $\mathrm{NE}$ & & & 22 G1. 6.3 & 1.36 & & & \\
\hline $13 \mathrm{M} 89$ & 0.45 & NE: & & & 2.361 .63 & 0.91 & & & \\
\hline $14 \mathrm{M} 89$ & 0.05 & $\mathrm{NE}$ & & & $24 G 1.63$ & 1.02 & & & \\
\hline $1 \mathrm{M} 69$ & 140.39 & $\mathrm{NE}$ & & & $250 \mathrm{jl}, 6.3$ & 1.02 & & & \\
\hline $1 M 8 \times$ & 2.17 & & & & 26 GL.6.3 & 0.46 & & & \\
\hline $2 \mathrm{M} \times 8$ & 1.06 & & & & 27 GL.6.3 & 0.23 & & & \\
\hline $3 \mathrm{M} 8 \mathrm{~S}$ & 8.106 & & & & $28 \mathrm{GL} .6 .3$ & 0.91 & & & \\
\hline $4 M \times 8$ & 0.35 & & & & $290(3) 6.3$ & (1.80) & & & \\
\hline $5 \mathrm{M} 8 \mathrm{8}$ & 9.31 & & & & 30 cil 63 & 0.46 & & & \\
\hline $1 G 1.6 .3$ & $(1.36)$ & & & & $31 \mathrm{GL} 6.3$ & 0.23 & & & \\
\hline $2 G 1.6 .3$ & 0.48 & & & & 32 GLG 3 & 0.91 & & & \\
\hline $3($ il. 6.3 & 1.32 & & & & 3301.63 & 0.80 & & & \\
\hline 4 (il. 6.3 & 3.32 & & & & 34 GL.t. 3 & 0.46 & & & \\
\hline 501.6 .3 & $3 .(12$ & & & & $10 \mathrm{jL} 24$ & 2114 & & & \\
\hline 6031.03 & 0.4 .3 & & & & 201524 & 22.71 & & & \\
\hline $7 \mathrm{Gl} 6.3$ & 0.60 & & & & $1 G 1,69$ & 29.51 & & & \\
\hline 8031,63 & 0.80 & 0.010 & 1.25 & .125 & $2\left(\mathrm{Bl} . \mathrm{f}^{i}\right)$ & 28.23 & & & \\
\hline y(il.tes & 0.41 & & & & $.3(j 1.69)$ & $32.9 ?$ & & & \\
\hline 10031.63 & 4.42 & & & & & & & & \\
\hline
\end{tabular}


TABLE A1. Cellulosic Material by Visual Inspection of Bags (Concluded)

\begin{tabular}{|c|c|c|c|c|c|c|c|c|c|}
\hline $\begin{array}{l}\text { Bag } \\
\text { No. }\end{array}$ & $\begin{array}{l}\text { Total } \\
(\mathrm{kg})\end{array}$ & $\begin{array}{c}\text { Estimated } \\
(\mathrm{kg})\end{array}$ & $\begin{array}{c}\text { Actual } \\
(\mathrm{kg})\end{array}$ & $\begin{array}{c}\text { Difference } \\
(\mathrm{kg})\end{array}$ & $\begin{array}{l}\text { Bag } \\
\text { No. }\end{array}$ & $\begin{array}{l}\text { Total } \\
(\mathrm{kg})\end{array}$ & $\begin{array}{c}\text { Estimated } \\
(\mathrm{kg})\end{array}$ & $\begin{array}{c}\text { Actual } \\
(\mathrm{kg})\end{array}$ & $\begin{array}{c}\text { Difference } \\
(\mathrm{kg})\end{array}$ \\
\hline $1 \mathrm{MO65}$ & 2.56 & & & & $6 \mathrm{HF} 62$ & 3.75 & 1.54 & 1.54 & $0 .(0)$ \\
\hline $2 \mathrm{MO65}$ & 2.98 & & & & 7HF62 & 2.20 & 1.46 & 1.43 & +0.03 \\
\hline 3 MO65 & 3.52 & & & & $8 \mathrm{HFG2}$ & 2.11 & 1.39 & 1.32 & +0.07 \\
\hline $4 M 065$ & 3.69 & & & & $9 H F 62$ & 2.29 & 1.78 & 1.41 & +0.37 \\
\hline $5 M 065$ & 3.13 & & & & $10 \mathrm{HF} 62$ & 2.41 & 1.54 & 1.54 & 0.00 \\
\hline $6 \mathrm{MO65}$ & 3.20 & & & & $11 \mathrm{HF} 62$ & 2.28 & 1.54 & $1 .{ }^{\circ} 4$ & 0.00 \\
\hline $7 \mathrm{MO65}$ & 2.87 & & & & IIN 33 & 11.25 & & & \\
\hline $8 \mathrm{MO65}$ & 1.97 & & & & $1 \mathrm{IN} 51$ & 5.35 & & & \\
\hline $9 \mathrm{MO65}$ & 3.20 & & & & $2 \mathrm{IN} 51$ & 3.99 & 1.56 & 0.00 & +1.56 \\
\hline $10 M 065$ & 3.76 & & & & 3 IN5 51 & 15.24 & & & \\
\hline 11 MO65 & 3.44 & & & & 4IN5I & 14.76 & & & \\
\hline $12 \mathrm{MO} 65$ & 3.33 & & & & |R91 & 4.53 & & & \\
\hline $1 \mathrm{HF} 52$ & 2.23 & 1.54 & 1.54 & 0.00 & 2R91 & 4.31 & & & \\
\hline $2 \mathrm{HF} 52$ & 2.33 & $\mathrm{NE}$ & 1.54 & $N E$ & $3 R 91$ & 2.09 & & & \\
\hline $3 \mathrm{HF} 52$ & 2.31 & 1.54 & 1.54 & $0.06)$ & $4 \mathrm{R} 91$ & 2.03 & & & \\
\hline $4 \mathrm{HF} 52$ & 3.41 & 1.54 & 1.54 & $0.04)$ & $5 \mathrm{R} 91$ & 1.13 & & & \\
\hline $5 \mathrm{HF} .52$ & 2.29 & 1.23 & 1.33 & -0.10 & $6 \mathrm{R} 91$ & 1.11 & & & \\
\hline $6 \mathrm{HF}=52$ & 2.13 & 1.41 & 1.36 & +0.05 & 7R91 & 6.97 & 0.00 & 1.25 & -1.25 \\
\hline $7 \mathrm{HF} 52$ & 2.43 & 1.54 & 1.54 & 0.00 & 8R91 & 7.76 & & & \\
\hline 811F52 & 2.05 & 1.29 & 1.37 & -0.08 & $9 R 91$ & 3.94 & & & \\
\hline 9HF52 & 2.33 & 1.79 & 1.31 & +0.48 & $10 \mathrm{R} 91$ & 11.82 & & & \\
\hline $10 \mathrm{HF} 52$ & 1.98 & 1.37 & 1.29 & +0.08 & 11891 & 7.23 & & & \\
\hline $1111 \mathrm{FF} 52$ & 1.99 & 1.25 & 1.30 & -0.05 & 1699 & 5.12 & ME & & \\
\hline $1 \mathrm{HF}=62$ & 2.54 & 1.82 & 1.53 & +0.29 & 2099 & 7.29 & $\mathrm{NE}$ & & \\
\hline $2 H 1 F 62$ & 2.83 & 1.54 & 1.54 & 0.00 & $3 \mathrm{G} 99$ & 7.65 & $\mathrm{NE}$ & & \\
\hline $3 \mathrm{HF} 62$ & 1.85 & 1.36 & 1.32 & +0.02 & $4(399$ & 0.59 & $\mathrm{NE}$ & & \\
\hline $4 H \mathrm{H} \cdot 62$ & 2.56 & 1.54 & 1.54 & $0 .(x)$ & $x(39 y$ & 0.24 & $\mathrm{NE}$ & & \\
\hline $5 H F \sigma_{2}$ & 1.96 & 1.27 & 1.33 & -0.06 & & & & & \\
\hline
\end{tabular}

NF: Not estimated because of contamination on sutside of bags 
TABLE A2. Plastic Material by Visual Inspection of Bags

\begin{tabular}{|c|c|c|c|c|c|c|c|c|c|}
\hline $\begin{array}{l}\text { Bag } \\
\text { No. }\end{array}$ & $\begin{array}{c}\text { Total } \\
(\mathrm{kg})\end{array}$ & $\begin{array}{l}\text { Estimated } \\
(\mathrm{kg})\end{array}$ & $\begin{array}{l}\text { Actual } \\
(\mathrm{kg})\end{array}$ & $\begin{array}{c}\text { Difference } \\
(\mathrm{kg})\end{array}$ & $\begin{array}{l}\text { Bag } \\
\text { No. }\end{array}$ & $\begin{array}{l}\text { Total } \\
(\mathrm{kg})\end{array}$ & $\begin{array}{c}\text { Estimated } \\
(\mathrm{kg})\end{array}$ & $\begin{array}{c}\text { Actual } \\
(\mathrm{kg})\end{array}$ & $\begin{array}{c}\text { Difference } \\
(\mathrm{kg})\end{array}$ \\
\hline $10 C \%$ & 32.6 .3 & 16.31 & 14.97 & +1.34 & $9 W 069$ & 1.02 & 1.02 & $1 .(1) 2$ & 0.00 \\
\hline $1 D C 45$ & 20.6 .5 & 15.49 & 9.177 & +6.42 & lowC69 & 0.93 & 0.93 & 0.93 & $0.00)$ \\
\hline $1 \mathrm{WC} 42$ & 1.33 & 1.33 & 0.90 & +0.43 & $11 W(69)$ & 2.40 & 2.40 & 2.40 & $(0 .(K)$ \\
\hline $2 W C 42$ & 0.97 & 0.97 & 0.97 & 0.00 & 12 WC69 & 3.52 & 3.52 & 3.52 & $0 .(1)$ \\
\hline $3 W C 42$ & 1.04 & 1.04 & 1.04 & $0 .(k)$ & $13 w(69$ & 0.86 & 0.86 & 0.86 & $0.0(0)$ \\
\hline $4 \mathrm{WC4} 2$ & 2.21 & 1.21 & 0.91 & +0.30 & 14 WCos & 0.24 & 0.24 & 0.24 & 0.00 \\
\hline $5 W C 42$ & 3.75 & 3.75 & $3.1 \mathrm{k}$ & +0.57 & $15 W C 69$ & 0.47 & 0.47 & 0.47 & 0.00 \\
\hline $6 \mathrm{WC42}$ & 2.96 & 2.96 & 2.90 & 0.00 & $1 P 60$ & 0.27 & 0.0 .3 & 0.16 & -0.13 \\
\hline $7 W C 42$ & 2.08 & 2.08 & 2.08 & 0.00 & $2 \mathrm{P} 60$ & 2.90 & 0.15 & 0.29 & -0.14 \\
\hline $8 W C 42$ & 3.08 & 3.08 & 3.08 & 0.00 & $3 \mathrm{P60}$ & 0.69 & 0.04 & 0.18 & -0.14 \\
\hline $9 \mathrm{WC4} 2$ & 2.08 & 2.08 & 1.82 & -0.26 & $4 P 60$ & 0.22 & 0.01 & 0.46 & -0.45 \\
\hline $10 W(42$ & $1.61)$ & 1.61 & 1.61 & 0.00 & $5 P^{p}(x)$ & 0.47 & 0.05 & 0.13 & $\cdots 0.08$ \\
\hline 11 WC42. & 1.31 & 1.31 & 1.20 & +0.11 & $6 \mathrm{P} 60$ & 1.20 & 0.01 & $0.31)$ & -0.29 \\
\hline $12 W C 42$ & 0.62 & 0.01 & 0.39 & -0.38 & $7 P(x)$ & 0.90 & 0.18 & 0.34 & $-0,16$ \\
\hline $1 \mathrm{WCR}$ & 4.40 & 4.40 & 4.39 & +0.01 & $8 P 60$ & 1.54 & 0.018 & 0.29 & -0.0 .21 \\
\hline $2 W C 88$ & 3.23 & 3.23 & 0.46 & +2.77 & yP60) & 0.32 & 0.03 & 0.27 & $\cdots 0.24$ \\
\hline $3 W C 88$ & 4.69 & 4.69 & 3.33 & +1.24 & $10 P(60)$ & 0.57 & 0.01 & 0.46 & -0.45 \\
\hline $4 W C 88$ & 1.24 & 1.24 & 1.24 & $0.60)$ & $11 \mathrm{P} 60$ & 0.70 & 0.01 & 0.14 & $\ldots 0.13$ \\
\hline $5 W C 88$ & 1.07 & 1.07 & 1.07 & $0 .(N)$ & $12 \mathrm{P} 60$ & 0.43 & 0.01 & 0,31 & -11.30 \\
\hline 6WC K8 & 26.76 & 26.76 & 15.42 & +11.34 & $13 P 008$ & 0.29 & 0.01 & 0.24 & $\cdots 0.23$ \\
\hline $1 \mathrm{WC}\left(0^{\circ}\right.$ & 2.188 & 2.188 & 2018 & $0,(H)$ & $14 P 60$ & 0.68 & 0.01 & 0.17 & $-(1) .16$ \\
\hline $2 W(6)$ & 2.51 & 2.51 & 2.51 & 0.00 & $15 P^{\circ} 60$ & 0.21 & 0.01 & 0.16 & -0.15 \\
\hline $3 w(69$ & 0.35 & 0.35 & 0.35 & 0.00 & $16 \mathrm{P} 60$ & 0.38 & 0.04 & 0.21 & -0.17 \\
\hline $4 W(69$ & 2.115 & 2.05 & 2.015 & $0.11)$ & $17 P(00$ & 0.78 & 0.014 & 0.33 & -0.29 \\
\hline swong & 2.45 & 2.45 & 245 & 0.00 & 18100 & 0.41 & 0.01 & 0.36 & 0.35 \\
\hline $6 w(69$ & 0.35 & 0.3 .5 & 0.35 & $0 .(x)$ & I9P(x) & 1.11 & 1.09 & 1.11 & $\cdots(1)(12$ \\
\hline $7 W(69)$ & 1.49 & 1.49 & 1.49 & $0 .(x)$ & $2(1 \mathrm{P} 60)$ & 1.62 & 1.50 & 1.62 & $\quad 0.013$ \\
\hline$K W(6)$ & 1.21 & 1.21 & 1.21 & $0.00)$ & $21 \mathrm{POO}$ & 7.113 & $7.0 \mathrm{~s}$ & 4.54 & +2.49 \\
\hline
\end{tabular}


TABLE A2. Plastic Material by Visual Inspection of Bags (Continued)

\begin{tabular}{|c|c|c|c|c|c|c|c|c|c|}
\hline $\begin{array}{l}\text { Bang } \\
\text { No. }\end{array}$ & $\begin{array}{l}\text { Total } \\
\text { (kg) }\end{array}$ & $\begin{array}{l}\text { Estimated } \\
\qquad(\mathrm{kg})\end{array}$ & $\begin{array}{c}\text { Actual } \\
(\mathrm{kg})\end{array}$ & $\begin{array}{l}\text { Difference } \\
\left(\mathrm{k}_{\mathrm{g}}\right)\end{array}$ & $\begin{array}{l}\text { Bag } \\
\text { No. }\end{array}$ & $\begin{array}{l}\text { Tottal } \\
(\mathrm{kg})\end{array}$ & $\begin{array}{l}\text { Estimated } \\
(\mathrm{kg})\end{array}$ & $\begin{array}{c}\text { Actual } \\
(\mathrm{kg})\end{array}$ & $\begin{array}{l}\text { Difference } \\
\qquad(\mathrm{kg})\end{array}$ \\
\hline $1 \mathrm{M} 89$ & 1.44 & 0.01 & 0.20 & -0.19 & $11 G L 63$ & 1.93 & 0.02 & 0.11 & $\cdots 0.09$ \\
\hline $2 M 89$ & 2.01 & 0.20 & 0.33 & -0.13 & $12 \mathrm{GI} .63$ & 1.47 & 0.011 & 0.06 & -0.05 \\
\hline $3 \mathrm{M} 89$ & 5.80 & 0.58 & 0.70 & -0.12 & 13GL63 & 0.45 & & & \\
\hline $4 \mathrm{M} 89$ & 10,36 & 0.10 & 0.38 & -0.23 & 14GL63 & 1.36 & 0.01 & 0.00 & $+(0.01$ \\
\hline $5 M 89$ & 1.13 & 0.01 & 0.100 & +0.01 & $15 \mathrm{GL} 63$ & 0.23 & 0.01 & 0.00 & +0.01 \\
\hline $6 \mathrm{M} 89$ & 7.60 & 0.38 & 0.34 & +0.04 & $16 \mathrm{GL} 63$ & 0.46 & 0.01 & 0.00 & $+(1.01$ \\
\hline $7 \mathrm{M} 89$ & 5.05 & 0.05 & 0.51 & -0.46 & 17 GL.63 & 1.25 & 0.02 & 0.00 & +0.02 \\
\hline $8 \mathrm{M} 89$ & 1.13 & 0.01 & 0.00 & +0.01 & 18 GLo3 & 0.68 & 0.01 & 0.00 & +0.01 \\
\hline $9 M 89$ & 0.23 & $\mathrm{NE}$ & 0.17 & $N E$ & 19 GL.6.3 & 1.36 & 0.01 & 0.00 & +0.01 \\
\hline $10 \mathrm{M} 89$ & 0.91 & $\mathrm{NE}$ & 0.45 & $\mathrm{NE}$ & 20 GL.63 & 4.99 & 0.05 & 0.11 & +0.00 \\
\hline $11 \mathrm{M} 89$ & 0.23 & $\mathrm{NE}$ & 0.12 & $\mathrm{NE}$ & 21 GL6 63 & 0.68 & 0.01 & 0.00 & +0.011 \\
\hline $12 \mathrm{M} 89$ & 0.34 & $\mathrm{NE}$ & 0.11 & NE: & 22GiL.6.3 & 1.36 & 0.01 & $0.00)$ & +0.01 \\
\hline $13 \mathrm{M} 89$ & 0.45 & $\mathrm{NE}$ & 0.22 & $\mathrm{NE}$ & 230.31 .0 .3 & 0.91 & 0.01 & 0.00 & +0.01 \\
\hline $14 \mathrm{M} 89$ & 0.05 & NE: & 0.04 & $\mathrm{NE}$ & $24 \mathrm{GL} 6.3$ & 1.02 & 0.01 & 0.00 & +0.01 \\
\hline $1 M 0,9$ & 140.39 & $\mathrm{NE}$ & 7.60 & $\mathrm{NE}$ & $25 G L 63$ & 1.02 & 0.01 & 0.00 & +0.01 \\
\hline $1 \mathrm{M} 88$ & 2.17 & 0.44 & 1.26 & -0.84 & $26 G 1.63$ & 0.46 & 0.01 & 0.00 & +0.01 \\
\hline $2 M 88$ & 1.06 & 0.21 & 0.83 & -0.62 & $27 \mathrm{GL} .63$ & 0.23 & 0.01 & 0.00 & $+(0.01$ \\
\hline $3 \mathrm{M} 88$ & 8.06 & 6.45 & 4.43 & +2.02 & $280 \mathrm{GL} 63$ & 0.91 & 0.01 & 0.00 & +0.01 \\
\hline $4 M 88$ & 0.35 & 0.28 & 0.2 .3 & +0.65 & 290163 & 0.80 & 0.01 & 0.00 & +0.01 \\
\hline $5 \mathrm{M} 8 \mathrm{~S}^{\prime}$ & 9.31 & 2.80 & 2.185 & +0.75 & $30<31.63$ & 0.46 & 0.01 & 0.00 & +0.01 \\
\hline IGL 63 & 0.36 & $0.0 \%$ & 0.2 .5 & -0.25 & 31 GLKB 3 & 0.23 & 0.01 & 0.00 & +0.01 \\
\hline 2016.63 & 1145 & $0.01)$ & $(1.0 .3$ & -0.0 .3 & $32 \mathrm{GL} 63$ & 0.91 & 0.01 & $0.00)$ & +0.01 \\
\hline $30 L 6.3$ & 1.32 & & & & 330.6163 & 0.80 & 0.01 & 0.00 & +0.01 \\
\hline $4 \mathrm{Gl} .63$ & 3.32 & 0.32 & 0.45 & -0.13 & 3401.63 & 0.46 & 0.01 & 0.00 & +0.01 \\
\hline SGilfo.3 & 3.112 & 0.30 & 0.45 & -0.15 & $|G| 24$ & 21.14 & 0.80 & 1.24 & -0.44 \\
\hline 6051.6 .3 & 0.43 & 0.01 & 0.00 & +0.011 & 2 GrL24 & 22.71 & 0.88 & 1.25 & $\ldots(0.37$ \\
\hline $7(\mathrm{gLB}, 3$ & 0.60 & 0.01 & 0.15 & -0.14 & IGil.6y & 29.51 & 0.93 & 0.87 & +0.06 \\
\hline$x$ Gilo. 3 & 6.80 & 0.07 & 0.11 & $\ldots 1) .03$ & $2(31.69)$ & 28.23 & 1.37 & 0.94 & +0.4 .3 \\
\hline $9(31.163$ & 0.91 & 0.01 & $0 .(80)$ & +0.101 & $3\left(31,6^{\circ}\right)$ & .32 .92 & 1.37 & 1.21 & +0.10 \\
\hline 10 GLo63 & 4.42 & 0.04 & 0.11 & -0.07 & & & & & \\
\hline
\end{tabular}


TABLE A2. Plastic Material by Visual Inspection of Bags (Concluded)

\begin{tabular}{|c|c|c|c|c|c|c|c|c|c|}
\hline $\begin{array}{l}\text { Bag } \\
\text { No, }\end{array}$ & $\begin{array}{l}\text { Total } \\
\text { (kg) }\end{array}$ & $\begin{array}{l}\text { Estimated } \\
\qquad(\mathrm{kg})\end{array}$ & $\begin{array}{c}\text { Actual } \\
(\mathrm{kg})\end{array}$ & $\begin{array}{l}\text { Difference } \\
\quad(\mathrm{kg})\end{array}$ & $\begin{array}{l}\text { Bagg } \\
\text { No. }\end{array}$ & $\begin{array}{l}\text { Total } \\
(\mathrm{kg})\end{array}$ & $\begin{array}{l}\text { Estimated } \\
\quad(\mathrm{kg})\end{array}$ & $\begin{array}{l}\text { Actual } \\
(\mathrm{kg})\end{array}$ & $\begin{array}{l}\text { Difference } \\
(\mathrm{kg})\end{array}$ \\
\hline $1 \mathrm{MO6} 5$ & 2.56 & 0.98 & 0,91 & +0.107 & $6 \mathrm{HI} 62$ & 3.75 & 0.62 & 0.24 & +0.38 \\
\hline $2 \mathrm{MO65}$ & 2.98 & 1.03 & 0.94 & +0.09 & $7 H F 62$ & 2.20 & 0.44 & 0.47 & -0.0 .3 \\
\hline $3 \mathrm{MOO} 5$ & 3.52 & 1.01 & 0.93 & +0.08 & $8 \mathrm{HF} 62$ & 2.11 & 0.42 & 0.49 & $-0.0 \%$ \\
\hline $4 M O 6.5$ & 3.69 & 1.00 & 0.94 & +0.06 & $9 H F 62$ & 2.29 & 0.21 & 0.58 & -0.37 \\
\hline $5 \mathrm{MO} 65$ & 3.13 & 1.01 & 0.89 & +0.12 & $10 H 1 F(2$ & 2.41 & 0.40 & 0.41 & -0.01 \\
\hline $6 \mathrm{MO6.5}$ & 3.20 & 1.00 & 0.91 & -0.019 & $11 \mathrm{HF} 2$ & 2.28 & 0.15 & 0.33 & -0.18 \\
\hline $7 M 065$ & 2.87 & 1.03 & 0.92 & +0.11 & $11 \mathrm{~N} 33$ & 11.25 & & & \\
\hline $8 \mathrm{MO} 65$ & 1.97 & 1.04 & 0.86 & +0.15 & IIN51 & 5.35 & 0.25 & 0.44 & -0.19 \\
\hline $9 \mathrm{MO} 6.5$ & 3.20 & 1.00 & 0.92 & +0.08 & 2IN5] & 3.99 & 0.52 & 0.88 & -0.36 \\
\hline $10 \mathrm{MO65}$ & 3.76 & 1.02 & 0.9 .3 & +0.09 & 3IN.5I & 15.24 & 0.23 & 0.45 & -0.22 \\
\hline 11 MO6.5 & 3.44 & $1 .(0)$ & 0.90 & +0.11 & AINSI & 14.76 & 0.13 & 0.24 & $\cdots 0.11$ \\
\hline $12 \mathrm{MO} 065$ & 3.33 & 1.01 & 0.89 & +0.12 & $\mid R 91$ & 4.53 & 0.00 & 0.33 & -0.33 \\
\hline $1111: 52$ & 2.23 & 0.00 & 0.10 & $\cdots(0.11)$ & $2 R^{\prime} 31$ & 4.31 & 0.00 & 1.02 & -1.02 \\
\hline $2111: 52$ & 2.33 & NE & 0.10 & NI: & $3 \mathrm{R} 91$ & 2.09 & $0.00)$ & 0.28 & -11.28 \\
\hline $.3 H F 52$ & 2.31 & 0.00 & 0.10 & -0.10 & $4 \mathrm{R} 91$ & 2.03 & $0.00)$ & 0.22 & $\cdots(1,22$ \\
\hline 411152 & 3.41 & 0.98 & 1.33 & $\cdots(0.3 .5$ & $.5 \mathrm{R} 91$ & 1.13 & $0.0 \%)$ & 0.23 & $-\cdots 0.23$ \\
\hline$\$ H F \$ 2$ & 2.29 & 0.76 & 0.66 & +0.10 & $6 \mathrm{R} 91$ & 1.11 & $0.0(0)$ & 0.20 & -0.20 \\
\hline $6 \mathrm{HF} 52$ & 2.13 & 0.42 & 0.47 & -0.0 .05 & $7 \mathrm{ROI}$ & 6.97 & 0.00 & 0.68 & -0.68 \\
\hline $7 H 1552$ & 2.43 & 0.48 & 0.37 & +0.11 & $x R(91$ & 7.76 & 0.00 & 0.05 & -0.05 \\
\hline $81+152$ & 2.0 .5 & 0.46 & 0.38 & +0.08 & $9 R(y)$ & 3.94 & $0 .(1)$ & 0.31 & $\cdots 0.31$ \\
\hline $9 H 1: 52$ & 2.33 & 0.24 & 0.72 & -0.48 & $\left.10 R^{\prime}\right) 1$ & 11.82 & $0 .(\%)$ & 0.14 & $\cdots 0.14$ \\
\hline 1011552 & 1.98 & 0.31 & 0.39 & $\cdots(1,0, k$ & $11 \mathrm{R} 91$ & 7.2 .3 & $0.0(1)$ & 1.33 & $-1,3,3$ \\
\hline $1111 \% 52$ & 1.99 & 0.44 & 0.39 & +0.05 & 1699 & 5.12 & NE: & 0.05 & Nl: \\
\hline $111 \% 62$ & 2.54 & 0.42 & 0.71 & $-(1.29$ & $2(39)$ & 7.29 & NI: & 0.0 .5 & NI: \\
\hline $2 H F 62$ & $2,8:$ & 0.47 & 0.95 & $\cdots 0.48$ & $3(\mathrm{G} 99)$ & 7.6 .5 & NE: & 0.05 & NI: \\
\hline $3 H 1 \% 62$ & 1.85 & 0.21 & 0.23 & 0.012 & $4(5 \%)$ & 0.59 & NE: & 1.36 & NI: \\
\hline AHFo? & 2.56 & 0.42 & 0.51 & +0.09 & $x^{\prime}(j) y$ & (0.24 & NE & 0.24 & NI: \\
\hline SHEO2 & 1.96 & $0.31)$ & 0.33 & $+(0.061$ & & & & & \\
\hline
\end{tabular}

NI: Not estimated because of combanimation on sustde of bags 
TABLE A3. Rubber Material by Visual Inspection of Bags

\begin{tabular}{|c|c|c|c|c|c|c|c|c|c|}
\hline $\begin{array}{l}\text { Bag } \\
\text { No. }\end{array}$ & $\begin{array}{l}\text { Total } \\
(\mathrm{kg})\end{array}$ & $\begin{array}{c}\text { Estimated } \\
(\mathrm{kg})\end{array}$ & $\begin{array}{c}\text { Actual } \\
(\mathrm{kg})\end{array}$ & $\begin{array}{c}\text { Difference } \\
(\mathrm{kg})\end{array}$ & $\begin{array}{l}\text { Biag } \\
\text { No. }\end{array}$ & $\begin{array}{l}\text { Total } \\
(\mathrm{kg})\end{array}$ & $\begin{array}{c}\text { Estimated } \\
(\mathrm{kg})\end{array}$ & $\begin{array}{c}\text { Actual } \\
(\mathrm{kg})\end{array}$ & $\begin{array}{l}\text { Difference } \\
(\mathrm{kg})\end{array}$ \\
\hline $1 D C 71$ & 32.63 & & & & $9 \mathrm{WC} 69$ & 1.02 & & & \\
\hline IDC45 & 20.65 & & & & $10 \mathrm{WC6} 9$ & 0.9 .3 & & & \\
\hline $1 W C 42$ & 1.33 & & & & $11 W(6)$ & 2.40 & & & \\
\hline $2 W C 42$ & 0.97 & & & & $12 W(69)$ & 3.52 & & & \\
\hline $3 W C 42$ & 1.04 & & & & $13 W(6)$ & 0.86 & & & \\
\hline $4 W C 42$ & 2.21 & & & & $14 W(69$ & 0.24 & & & \\
\hline SWC42 & 3.75 & & & & $15 W^{\prime}(0)$ & 0.47 & & & \\
\hline $6 \mathrm{WC4} 2$ & 2.96 & & & & $1 P(x)$ & 0.27 & 0.24 & 0.11 & +0.13 \\
\hline TWC42 & 2.08 & & & & $2 \mathrm{P} 60$ & 2.90 & & & \\
\hline $8 \mathrm{WC} 42$ & 3.08 & & & & $3 P(x)$ & 0.69 & 0.61 & 0.46 & +0.15 \\
\hline 9 WC42 & 2.08 & & & & $4 P 60$ & 0.22 & 0.10 & 0.06 & +0.04 \\
\hline $10 \mathrm{WC} 42$ & 1.60 & & & & $5 \mathrm{P} 60$ & 0.47 & 0.42 & 0.34 & +0.08 \\
\hline $11 \mathrm{WC4} 2$ & 1.31 & & & & $6 \mathrm{P}^{2} 60$ & 1.20 & 1.19 & 0.90 & $+(0.29$ \\
\hline 12 WC42 & 0.62 & & & & $7 P(6)$ & 0.90 & 0.73 & 0.97 & +0.16 \\
\hline $1 W C 88$ & 4.40 & & & & $8 \mathrm{P}(1)$ & 1.5 .4 & 1.38 & 1.25 & +0.13 \\
\hline $2 W C 88$ & 3.23 & & & & $9 P(1)$ & 0.32 & 0.29 & 0.015 & +0.24 \\
\hline $3 W C 88$ & 4.69 & & & & $10 P(x)$ & 0.57 & 0.51 & 0.11 & +0.50 \\
\hline $4 W C 88$ & 1.24 & & & & 11100 & 0.70 & $(1.69$ & 0.56 & +0.13 \\
\hline $5 W C 88$ & 1.07 & & & & $12 \mathrm{P} 60$ & 0.43 & 0.01 & 0.06 & +0.05 \\
\hline $6 \mathrm{WC} 8 \mathrm{~B}$ & 26.76 & & & & $13 P(x)$ & 0.29 & 0.27 & 0.015 & +0.22 \\
\hline Iwcrs & 2.08 & & & & $14 \mathrm{P} 60$ & 0.618 & 0.67 & 0.51 & +0.10 \\
\hline $2 W(60$ & 2.51 & & & & $1.5 P^{\prime}(0)$ & 0.21 & & & \\
\hline $3 W(69)$ & 0.35 & & & & $16 P^{2}(0)$ & 0.38 & 0.30 & 0.160 & +0.24 \\
\hline $4 W C 69$ & 2.05 & & & & $17 P(0)$ & 0.78 & 0.70 & 0.17 & +0.53 \\
\hline $5 W(60)$ & 2.45 & & & & $18 P(60)$ & 0.41 & 0.40 & 0.05 & +0.35 \\
\hline 61069 & 0.35 & & & & $10 P(x)$ & 1.11 & 0.112 & $0.00)$ & +0.02 \\
\hline $7 W 069$ & 1.49 & & & & $20 P(0)$ & 1.62 & 0.10 .3 & 0.00 & +0.013 \\
\hline $8 W(69$ & 1.21 & & & & $21 \mathrm{P}(1)$ & 7.013 & & & \\
\hline
\end{tabular}




\section{RFP-4604}

TABLE A3. Rubber Material by Visual Inspection of Bags (Continued)

\begin{tabular}{|c|c|c|c|c|c|c|c|c|c|}
\hline $\begin{array}{l}\text { Bag } \\
\text { No. }\end{array}$ & $\begin{array}{l}\text { Total } \\
(\mathrm{kg})\end{array}$ & $\begin{array}{c}\text { Estimated } \\
(\mathrm{kg})\end{array}$ & $\begin{array}{c}\text { Actual } \\
(\mathrm{kg})\end{array}$ & $\begin{array}{c}\text { Difforence } \\
(\mathrm{kg})\end{array}$ & $\begin{array}{l}\text { Bag } \\
\text { No. }\end{array}$ & $\begin{array}{l}\text { Total } \\
(\mathrm{kg})\end{array}$ & $\begin{array}{c}\text { Estimated } \\
(\mathrm{kg})\end{array}$ & $\begin{array}{c}\text { Actual } \\
(\mathrm{kg})\end{array}$ & $\begin{array}{c}\text { Difference } \\
(\mathrm{kg})\end{array}$ \\
\hline $1 \mathrm{M} 89$ & 1.44 & & & & 11GL6? & 1.93 & & & \\
\hline $2 \mathrm{M} 89$ & 2.01 & & & & 12 GL63 & 1.47 & & & \\
\hline $3 M 89$ & 5.80 & & & & $13 \mathrm{GL} 63$ & 0.45 & & & \\
\hline $4 \mathrm{M} 89$ & 10.36 & & & & $14 \mathrm{GL} 63$ & 1.36 & & & \\
\hline $5 \mathrm{M} 89$ & 1.13 & & & & $15 \mathrm{GL} 63$ & 0.23 & & & \\
\hline $6 \mathrm{M} 89$ & 7.60 & & & & $160 \mathrm{GL} 63$ & 0.46 & & & \\
\hline $7 \mathrm{M} 89$ & 5.05 & & & & 17 GiL63 & 1.25 & & & \\
\hline $8 \mathrm{M} 89$ & 1.13 & $\mathrm{NE}$ & & & $18 \mathrm{GL63}$ & 0.68 & & & \\
\hline $9 \mathrm{M} 89$ & 0.23 & $\mathrm{NE}$ & & & 19 GL63 & 1.36 & & & \\
\hline $10 \mathrm{M} 89$ & 0.91 & $\mathrm{NE}$ & & & $20 \mathrm{GL} 63$ & 4.99 & & & \\
\hline $11 \mathrm{M} 89$ & 0.23 & $\mathrm{NE}$ & & & $21 \mathrm{GL} 63$ & 0.68 & & & \\
\hline $12 \mathrm{M} 89$ & 0.34 & $N E$ & & & 22 GL 63 & 1.36 & & & \\
\hline $13 \mathrm{M} 89$ & 0.45 & $\mathrm{NE}$ & & & $23 \mathrm{GL} 6.3$ & 0.91 & & & \\
\hline $14 \mathrm{M} 89$ & 0.05 & $\mathrm{NE}$ & & & 24 GL 63 & 1.02 & & & \\
\hline $1 M 69$ & 140.39 & $N E$ & & & 25 GL6 63 & 1.02 & & & \\
\hline $1 \mathrm{M} 88$ & 2.17 & & & & $26 \mathrm{GL} 633$ & 0.46 & & & \\
\hline $2 \mathrm{M} 88$ & 1.06 & & & & 27 GL 63 & 0.23 & & & \\
\hline $3 \mathrm{M} 88$ & 8.06 & & & & $28 \mathrm{GL} 63$ & 0.91 & & & \\
\hline $4 \mathrm{M} 88$ & 0.35 & & & & $29 \mathrm{GL} 63$ & 0.80 & & & \\
\hline $5 \mathrm{M} 88$ & 9.31 & & & & $30 \mathrm{GL} 63$ & 0.46 & & & \\
\hline 1 GL63 3 & 0.36 & & & & 31 GL.63 & 0.23 & & & \\
\hline 2 GL6 63 & 0.48 & & & & $32 \mathrm{GL} 63$ & 0.91 & & & \\
\hline 3 GL.63 & 1.32 & & & & $33 \mathrm{CL} 6 \mathrm{63}$ & 0.80 & & & \\
\hline $4 G L 63$ & 3.32 & & & & 34 CiL.6.3 & 0.46 & & & \\
\hline $5 \mathrm{GL} .63$ & $3 .(12$ & & & & $1 \mathrm{GL} 24$ & 21.14 & & & \\
\hline 601603 & 0.43 & & & & $2 \mathrm{GL} 24$ & 22.71 & & & \\
\hline 7 GLo63 & 0.60 & & & & 161.69 & 29.51 & & & \\
\hline 8 GLL63 & 6.80 & & & & $2(3169$ & 28.23 & & & \\
\hline $9(61.163$ & 0.91 & & & & 3 (i). 69 & 32.92 & & & \\
\hline 1006.63 & 4.42 & & & & & & & & \\
\hline
\end{tabular}

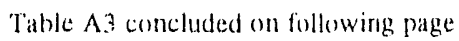


TABLE A3. Rubber Material by Visual Inspection of Bags (Concluded)

\begin{tabular}{|c|c|c|c|c|c|c|c|c|c|}
\hline $\begin{array}{l}\text { Bag } \\
\text { No. }\end{array}$ & $\begin{array}{l}\text { lotal } \\
(\mathrm{kg})\end{array}$ & $\begin{array}{l}\text { Estimated } \\
(\mathrm{kg})\end{array}$ & $\begin{array}{c}\text { Actual } \\
(\mathrm{kg})\end{array}$ & $\begin{array}{c}\text { Difference } \\
(\mathrm{kg})\end{array}$ & $\begin{array}{l}\text { Bag } \\
\text { No. }\end{array}$ & $\begin{array}{l}\text { Total } \\
(\mathrm{kg})\end{array}$ & $\begin{array}{c}\text { Estimated } \\
(\mathrm{kg})\end{array}$ & $\begin{array}{c}\text { Actual } \\
(\mathrm{kg})\end{array}$ & $\begin{array}{c}\text { Difference } \\
(\mathrm{kg})\end{array}$ \\
\hline $1 \mathrm{MO} 65$ & 2.56 & & & & $6 \mathrm{HF} 62$ & 3.75 & 0.0 .3 & 0.03 & $0.00)$ \\
\hline $2 \mathrm{MOO} .5$ & 2.98 & & & & $7 \mathrm{HF} 62$ & 2.20 & 0.03 & 0.03 & 0.00 \\
\hline $3 \mathrm{MO} 6.5$ & 3.52 & & & & $8 \mathrm{HF} 62$ & 2.11 & 0.03 & 0.03 & 0.00 \\
\hline $4 \mathrm{MO6} 5$ & 3.69 & & & & 9HF62 & 2.29 & 0.03 & 0.03 & 0.00 \\
\hline $5 \mathrm{MO} 65$ & 3.13 & & & & $10 \mathrm{HF} 62$ & 2.41 & 0.03 & 0.03 & 0.00 \\
\hline $6 M O 65$ & 3.20 & & & & $11 \mathrm{HF} 62$ & 2.28 & 0.03 & 0.03 & 0.00 \\
\hline $7 \mathrm{MO65}$ & 2.87 & & & & $1 \mathrm{IN} 33$ & 11.25 & & & \\
\hline $8 M 065$ & 1.97 & & & & $11 N 51$ & 5.35 & & & \\
\hline $9 \mathrm{MO} 6.5$ & 3.20 & & & & $21 N 51$ & 3.99 & & & \\
\hline $10 \mathrm{MO} 65$ & 3.76 & & & & 3 IN.S1 & 15.24 & & & \\
\hline $11 \mathrm{MOOS}$ & 3.44 & & & & 4IN51 & 14.76 & & & \\
\hline $12 \mathrm{MO} 65$ & 3.33 & & & & $1 \mathrm{R} 91$ & 4.53 & 1.68 & 1.56 & +0.12 \\
\hline $1 \mathrm{HFS2}$ & 2.23 & 0.03 & 0.03 & 0.00 & 2R91 & 4.31 & 1.60 & 1.22 & +0.38 \\
\hline $2 \mathrm{HF52}$ & 2.33 & $\mathrm{NE}$ & 0.03 & $\mathrm{NE}$ & $3 R 91$ & 2.09 & 0.78 & 0.67 & +0.11 \\
\hline $3 H \mathrm{H}: 52$ & 2.31 & 0.03 & 0.03 & 0.00 & $4 \mathrm{R} 91$ & 2.03 & 0.75 & 0.67 & $\begin{array}{r}+0.08 \\
\end{array}$ \\
\hline $4111: 52$ & 3.41 & 0.03 & 0.03 & 0.00 & $5 \mathrm{R} 91$ & 1.13 & 0.42 & 0.34 & +0.08 \\
\hline $5111 \times 52$ & 2.29 & 0.033 & 0.03 & $0.00)$ & 6R91 & 1.11 & 0.41 & 0.34 & +0.07 \\
\hline $64 \% 52$ & 2.13 & 0.03 & 0.03 & 0.00 & $7 \mathrm{R} 91$ & 6.97 & 2.59 & 1.87 & +0.72 \\
\hline 7111552 & 2.43 & 0.03 & 0.03 & 0.00 & $8 \mathrm{R} 91$ & 7.76 & 2.88 & 2.86 & +0.02 \\
\hline $8 \mathrm{HI}: 52$ & 2.05 & 0.03 & 0.0 .3 & 0.00 & $9 \mathrm{R} 91$ & 3.94 & 1.46 & 1.3. & +0.11 \\
\hline $94 F 52$ & 2.33 & 0.03 & 0.03 & 0.00 & $10 R 91$ & 11.82 & 4.39 & 4.34 & +0.05 \\
\hline $10 H \mathrm{HF} 52$ & 1.98 & 0.03 & 0.03 & 0.00 & $11 \mathrm{R} 91$ & 7.23 & 2.69 & 2.19 & +0.50 \\
\hline 11145552 & 1.99 & 0.0 .3 & 0.0 .3 & $0 .(x)$ & 1099 & 5.12 & NE: & & \\
\hline $1 \mathrm{HI}: 62$ & 2.54 & 0.03 & 0.03 & 0.00 & 2099 & 7.29 & $\mathrm{NE}$ & & \\
\hline $2 H F 62$ & 2.83 & 0.03 & 0.03 & 0.00 & 3099 & 7.65 & NE: & & \\
\hline $3 H F=62$ & 1.8 .5 & 0.0 .3 & 0.03 & 0.00 & 4099 & 6.59 & $\mathrm{Nl}$ & & \\
\hline 411562 & 2.56 & 0.03 & 0.03 & 0.00 & $x G 99$ & 0.24 & NE: & & \\
\hline $5 H I: 62$ & 1.96 & 0.03 & 0.0 .3 & 0.100 & & & & & \\
\hline
\end{tabular}

NL - Nol estimateal because of contamination on outside of bags 
TABLE A4. Corroding Metal/Steel Material by Visual Inspection of Bags

\begin{tabular}{|c|c|c|c|c|c|c|c|c|c|}
\hline $\begin{array}{l}\text { Bag } \\
\text { No. }\end{array}$ & $\begin{array}{l}\text { Total } \\
(\mathrm{kg})\end{array}$ & $\begin{array}{l}\text { Estimated } \\
(\mathrm{kg})\end{array}$ & $\begin{array}{c}\text { Actual } \\
(\mathrm{kg})\end{array}$ & $\begin{array}{c}\text { Difference } \\
(\mathrm{kg})\end{array}$ & $\begin{array}{l}\text { Bag } \\
\text { No. }\end{array}$ & $\begin{array}{l}\text { Total } \\
(\mathrm{kg})\end{array}$ & $\begin{array}{l}\text { Estimated } \\
(\mathrm{kg})\end{array}$ & $\begin{array}{c}\text { Actual } \\
(\mathrm{kg})\end{array}$ & $\begin{array}{c}\text { Difference } \\
(\mathrm{kg})\end{array}$ \\
\hline $1 D C 71$ & 32.63 & & & & $9 W 069$ & 1.02 & & & \\
\hline $10 C 45$ & 20.65 & & & & $10 \mathrm{WC69}$ & 0.93 & & & \\
\hline 1 WC 42 & 1.33 & & & & $11 w C 69$ & 2.40 & & & \\
\hline $2 W C 42$ & $0.9^{\prime} 7$ & & & & 12 WC69 & 3.52 & & & \\
\hline $3 W C 42$ & 1.04 & & & & 13 WC69 & 0.86 & & & \\
\hline $4 W C 42$ & 2.21 & & & & $14 W(69)$ & 0.24 & & & \\
\hline $5 \mathrm{WC} 42$ & 3.75 & & & & 15 WC69 & 0.47 & & & \\
\hline 6WC42 & 2.96 & & & & $1 \mathrm{P} 60$ & 0.27 & & & \\
\hline $7 \mathrm{WC4} 2$ & 2.08 & & & & $2 \mathrm{P} 60$ & 2.90 & & & \\
\hline $8 W C 42$ & 3.08 & & . & & $3 \mathrm{P} 60$ & 0.69 & & & \\
\hline $9 \mathrm{WC} 42$ & 2.08 & & & & $4 \mathrm{P} 60$ & 0.22 & & & \\
\hline 10 WC42 & 1.60 & & & & $5 \mathrm{P} 60$ & 0.47 & & & \\
\hline $11 \mathrm{WC} 42$ & 1.31 & & & & $6 \mathrm{P} 60$ & 1.20 & & & \\
\hline $12 \mathrm{WC} 42$ & 0.62 & & & & $7 \mathrm{P} 60$ & 0.90 & & & \\
\hline $1 W C 88$ & 4.40 & & & & $8 P 60$ & 1.54 & & & \\
\hline $2 W C 88$ & 3.23 & & & & $9 P_{60}$ & 0.32 & & & \\
\hline 3 WC 88 & 4.69 & & & & $10 \mathrm{P} 60$ & 0.57 & & & \\
\hline $4 W C 88$ & 1.24 & & & & $11 \mathrm{P} 60$ & 0.70 & & & \\
\hline $5 W C 88$ & 1.07 & & & & $12 \mathrm{P} 60$ & 0.43 & & & \\
\hline $6 \mathrm{WC8} 8$ & 26.76 & & & & $13 \mathrm{P} 60$ & 0.29 & & & \\
\hline $1 W C 69$ & 2.08 & & & & $14 \mathrm{P} 60$ & 0.69 & & & \\
\hline $2 W C 69$ & 2.51 & & & & $1.5 \mathrm{P} 60$ & 0.21 & & & \\
\hline $3 W C 69$ & 0.35 & & & & $16 \mathrm{P} 60$ & 0.38 & & & \\
\hline $4 W(69)$ & 2.05 & & & & $17 \mathrm{P} 60$ & 0.78 & & & \\
\hline $5 w 069$ & 2.45 & & & & $18 \mathrm{P} 60$ & 0.41 & & & \\
\hline $6 W C 69$ & 0.35 & & & & $19 P 60$ & 1.11 & & & \\
\hline $7 W(69$ & 1.49 & & & & $20 \mathrm{P} 60$ & 1.62 & & & \\
\hline $8 W C 69$ & 1.21 & & & & $21 P 00$ & 7.03 & & & \\
\hline
\end{tabular}

Table A4 continued on following page 
TABLE A4, Corroding Metal/Steel Material by Visual Inspection of Bags (Continued)

\begin{tabular}{|c|c|c|c|c|c|c|c|c|c|}
\hline $\begin{array}{l}\text { Batg: } \\
\text { No. }\end{array}$ & $\begin{array}{l}\text { Total } \\
(\mathrm{kg})\end{array}$ & $\begin{array}{l}\text { Estimated } \\
(\mathrm{kg})\end{array}$ & $\begin{array}{c}\text { Actual } \\
(\mathrm{kg})\end{array}$ & $\begin{array}{l}\text { Difference } \\
\quad(\mathrm{kg})\end{array}$ & $\begin{array}{l}\text { Bag } \\
\text { No. }\end{array}$ & $\begin{array}{l}\text { Total } \\
(\mathrm{kg})\end{array}$ & $\begin{array}{l}\text { Estimated } \\
(\mathrm{kg})\end{array}$ & $\begin{array}{c}\text { Actual } \\
(\mathrm{kg})\end{array}$ & $\begin{array}{l}\text { Difference } \\
\qquad(\mathrm{kg})\end{array}$ \\
\hline $1 \mathrm{M} 89$ & 1.44 & 1.43 & 1.24 & +0.19 & 11 GL6.3 & 1,93 & & & \\
\hline $2 \mathrm{M} 89$ & 2.01 & 0.00 & 1.40 & -1.40 & 12GL63 & 1.47 & & & \\
\hline $.3 \mathrm{M} 89$ & 5.80 & 5.22 & 5.10 & +0.12 & 13 GL6.3 & 0.45 & & & \\
\hline $4 \mathrm{M} 89$ & 10.36 & 10.26 & 9.98 & +0.28 & $14 \mathrm{GL} 63$ & 1.36 & & & \\
\hline $5 \mathrm{M} 89$ & 1.13 & 1.12 & 1.13 & -0.01 & $1.5 \mathrm{GL} 63$ & 0.23 & & & \\
\hline $6 \mathrm{M} 89$ & 7.60 & 5.32 & 4.99 & $+0,33$ & $16 \mathrm{GL} .63$ & 0.46 & & & \\
\hline $7 \mathrm{M} 89$ & 5.05 & $\therefore(00)$ & 1.25 & +3.75 & 17GL63 & 1.25 & & & \\
\hline $8 \mathrm{M} 89$ & 1.13 & 1.12 & 1.13 & -0.01 & 18 GL63 & 0.68 & & & \\
\hline $9 \mathrm{M} 89$ & 0.23 & $N E$ & 0.06 & $N E$ & 19 GL63 & 1.36 & & & \\
\hline $10 \mathrm{M} 89$ & 0.91 & NE & 0.46 & $\mathrm{NE}$ & 20 GL 63 & 4.99 & & & \\
\hline $11 \mathrm{M} 89$ & 0.23 & NE & 0.11 & $\mathrm{NE}$ & $2.1 \mathrm{GL} 63$ & 0.68 & & & \\
\hline $12 \mathrm{M} 89$ & 0.34 & NE & 0.23 & $N E$ & 22 GLGG 3 & 1.36 & & & \\
\hline $13 \mathrm{M} 89$ & 0.45 & $\mathrm{NE}$ & 0.23 & NE & 23 GL6 63 & 0.91 & & & \\
\hline $14 \mathrm{M} 89$ & 0.05 & $\mathrm{NE}$ & 0.01 & $\mathrm{NE}$ & 24 GL 63 & $1 .(12$ & & & \\
\hline $1 \mathrm{M} 69$ & 140.39 & $\mathrm{NE}$ & 131.77 & $\mathrm{NE}$ & 25 GL6 63 & 1.02 & & & \\
\hline $1 \mathrm{M} 88$ & 2.17 & 1.73 & 0.91 & +0.82 & 26 GiL6.3 & 0.46 & & & \\
\hline $2 \mathrm{M} 88$ & 1.06 & 0.85 & (). 2.3 & +0.62 & $27 \mathrm{GL} 63$ & 0.23 & & & \\
\hline $3 \mathrm{M} 8 \mathrm{~B}$ & 8.06 & 0.00 & 3,18 & -3.18 & $28 \mathrm{GL} 63$ & 0.91 & & & \\
\hline $4 \mathrm{M} 8 \mathrm{8}$ & 0.35 & 0.07 & 0.12 & -0.0 .5 & 29 GL6.3 & $(0.80$ & & & \\
\hline $5 \mathrm{M} 88$ & 9.31 & 4.6 .5 & 6.35 & -1.70 & 30 GL63 & 0.46 & & & \\
\hline IGL.6.3 & 0.36 & & & & 31 GL63 3 & 0.23 & & & \\
\hline 201.6 .3 & $0.4 k$ & & & & 32010.3 & 0.91 & & & \\
\hline $3(31.63$ & 1.32 & & & & 33GL63 & 0.80 & & & \\
\hline 4GL6? & 3.32 & & & & $34 \mathrm{GL} 6.3$ & 0.46 & & & \\
\hline $5(i 10.3$ & 3.122 & & & & $1 \mathrm{GL} 24$ & 21.14 & & & \\
\hline SOL.6.3 & 0.4 .3 & & & & 2 cil.24 & 22.71 & & & \\
\hline 761.63 & 0.60 & & & & 161.69 & 29.51 & & & \\
\hline $8(31.63$ & 6.80 & & & & 2(SL6) & 28.23 & & & \\
\hline gGillo.3 & 0.91 & & & & $3(120,4)$ & .32 .92 & & & \\
\hline 1001.6 .3 & 4.42 & & & & & & & & \\
\hline
\end{tabular}


TABLE A4. Corroding Metal/Steel Material by Visual Inspection of Bags (Concluded)

\begin{tabular}{|c|c|c|c|c|c|c|c|c|c|}
\hline $\begin{array}{l}\text { Bag } \\
\text { No. }\end{array}$ & $\begin{array}{l}\text { Total } \\
(\mathrm{kg})\end{array}$ & $\begin{array}{c}\text { Estimated } \\
(\mathrm{kg})\end{array}$ & $\begin{array}{c}\text { Actual } \\
(\mathrm{kg})\end{array}$ & $\begin{array}{c}\text { Difference } \\
(\mathrm{kg})\end{array}$ & $\begin{array}{l}\text { Bag } \\
\text { No. }\end{array}$ & $\begin{array}{l}\text { Total } \\
(\mathrm{kg})\end{array}$ & $\begin{array}{c}\begin{array}{c}\text { Estimated } \\
(\mathrm{kg})\end{array} \\
\end{array}$ & $\begin{array}{c}\text { Actual } \\
(\mathrm{kg})\end{array}$ & $\begin{array}{c}\text { Difference } \\
(\mathrm{kg})\end{array}$ \\
\hline $1 \mathrm{MO65}$ & 2.56 & & & & $6 \mathrm{HF}^{2} 2$ & 3.75 & & & \\
\hline $2 \mathrm{MO} 65$ & 2.98 & & & & $7 \mathrm{HF} 62$ & 2.20 & & & \\
\hline $3 \mathrm{MO65}$ & 3.52 & & & & $8 \mathrm{HF}_{62}$ & 2.11 & & & \\
\hline $4 \mathrm{MO} 65$ & 3.69 & & & & 9HF62 & 2.29 & & & \\
\hline $5 \mathrm{MO65}$ & 3.13 & & & & $10 \mathrm{HF}_{62}$ & 2.41 & & & \\
\hline $6 \mathrm{MO65}$ & 3.20 & & & & $11 \mathrm{HF} 62$ & 2.28 & & & \\
\hline $7 \mathrm{MO} 65$ & 2,87 & & & & $11 N 33$ & 11.25 & 0.00 & 2.72 & -2.72 \\
\hline $8 M O 65$ & 1.97 & & & & $1 \mathrm{IN} 51$ & 5.35 & & & \\
\hline $9 \mathrm{MO65}$ & 3.20 & & & & 2IN51 & 3.99 & & & \\
\hline $10 \mathrm{MO} 65$ & 3.76 & & & & 3 IN51 & 15.24 & & & \\
\hline $11 \mathrm{MO65}$ & 3.44 & & & & $4 \mathrm{IN} 51$ & 14.76 & & & \\
\hline $12 \mathrm{MO} 65$ & 3,33 & & & & 1891 & 4.53 & & & \\
\hline 1HF52 & 2.23 & & & & $2 \mathrm{R} 91$ & 4,31 & & & \\
\hline 2HFS2 & 2.33 & $\mathrm{NE}$ & & & $3 \mathrm{R} 91$ & 2.09 & & & \\
\hline $3 \mathrm{HFS2}$ & 2.31 & & & & $4 \mathrm{R}^{0} 1$ & 2.01 .3 & & & \\
\hline $4 \mathrm{HF} 52$ & 3.41 & & & & SRO1 & 1.13 & & & \\
\hline 5HF52 & 2.29 & & & & $6 \mathrm{R} 91$ & 1.11 & & & \\
\hline $6 \mathrm{HF52}$ & 2.13 & & & & 7R91 & 6.97 & & & \\
\hline 7HF52 & 2.43 & & & & $8 \mathrm{R} 91$ & 7.76 & & & \\
\hline $8 \mathrm{HF} 52$ & 2.05 & & & & 9R.91 & 3.94 & & & \\
\hline 9HF52 & 2,33 & & & & $10 \mathrm{R} 91$ & 11.82 & & & \\
\hline $10 \mathrm{HF} 52$ & 1.98 & & & & $11 \mathrm{R} 91$ & 7.23 & & & \\
\hline $11 \mathrm{HF} 52$ & 1,99 & & & & $1 \mathrm{G99}$ & 5.12 & $\mathrm{NE}$ & & \\
\hline $1 \mathrm{HF} 62$ & 2.54 & & & & $2 \mathrm{G} 99$ & 7.29 & NI: & & \\
\hline $2 \mathrm{HF} 62$ & 2.83 & & & & $3 G 99$ & 7.65 & $\mathrm{NE}$ & & \\
\hline $3 H F 62$ & 1.85 & & & & $4 \mathrm{G} 99$ & 0.59 & $\mathrm{NE}$ & & \\
\hline $4 \mathrm{HF} 62$ & 2.56 & & & & XG99 & 0.24 & $\mathrm{NE}$ & & \\
\hline $5 \mathrm{HF} 62$ & 1.96 & & & & & & & & \\
\hline
\end{tabular}

NE - Not estimated because of combamination on outside of hags 
TABLE A5. Corroding Metal/Aluminum Material by Visual Inspection of Bags

\begin{tabular}{|c|c|c|c|c|c|c|c|c|c|}
\hline $\begin{array}{l}\text { Bag } \\
\text { No. }\end{array}$ & $\begin{array}{l}\text { Total } \\
(\mathrm{kg})\end{array}$ & $\begin{array}{c}\text { Estimated } \\
(\mathrm{kg})\end{array}$ & $\begin{array}{c}\text { Actual } \\
(\mathrm{kg})\end{array}$ & $\begin{array}{c}\text { Difference } \\
(\mathrm{kg})\end{array}$ & $\begin{array}{l}\text { Bag } \\
\text { No. }\end{array}$ & $\begin{array}{l}\text { Total } \\
(\mathrm{kg})\end{array}$ & $\begin{array}{c}\text { Estimated } \\
(\mathrm{kg})\end{array}$ & $\begin{array}{c}\text { Actual } \\
(\mathrm{kg})\end{array}$ & $\begin{array}{c}\text { Difference } \\
(\mathrm{kg})\end{array}$ \\
\hline $10 C 71$ & 32.63 & & & & $9 \mathrm{WC} 69$ & 1.02 & & & \\
\hline $1 D C 45$ & 20.65 & & & & $10 \mathrm{WC6})$ & 0.93 & & & \\
\hline $1 \mathrm{WC} 42$ & 1.33 & & & & $11 W C 60$ & 2.40 & & & \\
\hline $2 W C 42$ & 0.97 & & & & $12 \mathrm{WC}(69$ & 3.52 & & & \\
\hline $3 W C 42$ & 1.04 & & & & $1.3 \mathrm{WC69}$ & 0.86 & & & \\
\hline $4 W C 42$ & 2.21 & & & & $14 W C 69$ & 0.24 & & & \\
\hline 5 WC42 & 3.75 & & & & 15 WC69 & 0.47 & & & \\
\hline 6WC 42 & 2.96 & & & & $1 \mathrm{P60}$ & 0.27 & & & \\
\hline $7 \mathrm{WC} 42$ & 2.08 & & & & $2 \mathrm{P} 60$ & 2.90 & & & \\
\hline $8 W C 42$ & 3.08 & & & & $3 P 60$ & 0.69 & & & \\
\hline $9 \times C 42$ & 2.08 & & & & $4 \mathrm{P} 60$ & 0.22 & & & \\
\hline 10 WC42 & 1.60 & & & & $5 \mathrm{P}(0)$ & 0.47 & & & \\
\hline 11 WC42 & 1.31 & & & & $6 \mathrm{P} 60$ & 1.20 & & & \\
\hline $12 \mathrm{WC} 42$ & 0.62 & & & & $7 \mathrm{P} 60$ & 0.90 & & & \\
\hline $16 C 88$ & 4.40 & & & & $8 \mathrm{P} 60$ & 1.54 & & & \\
\hline $2 W C 88$ & 3.23 & & & & $9 P 60$ & 0.32 & & & \\
\hline $3 W C 88$ & 4.69 & & & & $10 \mathrm{P} 60$ & 0.57 & & & \\
\hline $4 W C 88$ & 1.24 & & & & $11 \mathrm{P} 60$ & 0.70 & & & \\
\hline $5 W C 88$ & 1.07 & & & & $12 P^{2} 60$ & 0.43 & & & \\
\hline $6 \mathrm{WC} 88$ & 26.76 & & & & $13 \mathrm{P}(0)$ & 0.29 & & & \\
\hline $1 W(69$ & 2.08 & & & & $14 \mathrm{P}(0)$ & 0.68 & & & \\
\hline $2 W 069$ & 2.51 & & & & $1.5 \mathrm{P} 60$ & 0.21 & & & \\
\hline 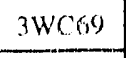 & 0.35 & & & & $16 \mathrm{P60}$ & 0,38 & & & \\
\hline $4 W(69)$ & 2.0 .5 & & & & $17 \mathrm{P} 60$ & 0.78 & & & \\
\hline $5 W 069$ & 2.45 & & & & $18 \mathrm{P} 60$ & $0.4 i$ & & & \\
\hline $6 \mathrm{~W}(6)$ & 0.35 & & & & $10 P(00$ & 1.11 & & & \\
\hline $7 W(69)$ & 1.49 & & & & $20 \mathrm{P} 60$ & 1.62 & & & \\
\hline $8 W 069$ & 1.21 & & & & $21 \mathrm{P}(0)$ & 7.03 & & & \\
\hline
\end{tabular}


TABLE A.5. Corroding Metal/Aluminum Material by Visual Inspection of Bags (Continued)

\begin{tabular}{|c|c|c|c|c|c|c|c|c|c|}
\hline $\begin{array}{l}\text { Bag } \\
\text { No. }\end{array}$ & $\begin{array}{l}\text { Total } \\
(\mathrm{kg})\end{array}$ & $\begin{array}{l}\text { Estimated } \\
\quad(\mathrm{kg})\end{array}$ & $\begin{array}{c}\text { Actual } \\
(\mathrm{kg})\end{array}$ & $\begin{array}{l}\text { Difference } \\
\quad(\mathrm{kg})\end{array}$ & $\begin{array}{l}\text { Bagg } \\
\text { No. }\end{array}$ & $\begin{array}{l}\text { Total } \\
(\mathrm{kg})\end{array}$ & $\begin{array}{c}\text { Estimated } \\
(\mathrm{kg})\end{array}$ & $\begin{array}{c}\text { Actual } \\
(\mathrm{kg})\end{array}$ & $\begin{array}{l}\text { Difference } \\
\quad(\mathrm{kg})\end{array}$ \\
\hline $1 M(s)$ & 1.44 & & & & 11 GL63.3 & 1.93 & & & \\
\hline $2 \mathrm{M} 89$ & 2.01 & & & & 12 Gi.6. 3 & 1.47 & & & \\
\hline $3 \mathrm{M} 89$ & 5.80 & & & & $13 \mathrm{GL} 6.3$ & 0.4 .5 & & & \\
\hline $4 \mathrm{M} \times 9$ & 10.36 & & & & 14GL6.3 & 1.36 & & & \\
\hline $5 \mathrm{M} 89$ & 1.13 & & & & $15 \mathrm{GL} 63$ & 0.23 & & & \\
\hline $6 \mathrm{M} 89$ & 7.60 & & & & 16GL63 & 0.46 & & & \\
\hline $7 \mathrm{M} 89$ & 5.05 & 0.00 & 2.27 & -2.27 & 17 GL6 63 & 1.25 & & & \\
\hline $8 \mathrm{M} 89$ & 1.13 & & & & $13 \mathrm{GL} 63$ & 0.68 & & & \\
\hline $9 \mathrm{M} 89$ & 0.23 & $\mathrm{NE}$ & & & 19 GL63 & 1.36 & & & \\
\hline $10 \mathrm{M} 89$ & 0.91 & $\mathrm{NE}$ & & & 20 GL 63 & 4.99 & & & \\
\hline $11 \mathrm{M} 89$ & 0.23 & NE: & & & $21 \mathrm{GL} 63$ & 0.68 & & & \\
\hline $12 \mathrm{M} 89$ & 0,34 & $\mathrm{NE}$ & & & 22GL63 & 1.36 & & & \\
\hline $13 \mathrm{M} 89$ & 0.45 & NE: & & & 23GL63 & 0.91 & & & \\
\hline $14 \mathrm{M} 89$ & 0.05 & $\mathrm{NE}$ & & & 24GL.6.3 & 1.02 & & & \\
\hline $1 M(6)$ & 140.39 & $\mathrm{NE}$ & & & 25 GL6. 3 & 1.02 & & & \\
\hline $1 M 88$ & 2.17 & & & & 26 GL6 3 & 0.46 & & & \\
\hline $2 \mathrm{M} \times 8$ & 1.00 & & & & 27 GL63 & 0.23 & & & \\
\hline $3 \mathrm{M} 88$ & R.ivo & & & & $28 \mathrm{GL} 63$ & 0.91 & & & \\
\hline $4 M 188$ & 0.35 & & & & $29 \mathrm{GL} 63$ & 0.80 & & & \\
\hline $5 \mathrm{M} 88$ & 9.31 & 1.86 & 0.91 & +0.95 & 30GL63 3 & 0.46 & & & \\
\hline 1 GL.6.3 & 0.36 & & & & 31 GL6.3 & 0.23 & & & \\
\hline $2 \mathrm{GL} 63$ & 0.48 & & & & $32 \mathrm{GL} 6.3$ & 0.91 & & & \\
\hline 3 GL, 6.3 & 1.32 & & & & 330403 & 0.80 & & & \\
\hline 4 GiL6.3 & 3.32 & & & & $340 \mathrm{OL} .03$ & 0.46 & & & \\
\hline $5 G \mathrm{Gl} 6.3$ & 3.112 & & & & 1 GL 24 & 21.14 & & & \\
\hline $60 \mathrm{sl}, 6,3$ & 0.43 & & & & $20 \mathrm{GL} .24$ & 22.71 & & & \\
\hline 7016.3 & 0.60 & & & & $1(\mathrm{Gl} .69)$ & 29.51 & & & \\
\hline $8(3), 6.3$ & 6.80 & & & & $2(\mathrm{il} 6 \mathrm{6})$ & 28.23 & & & \\
\hline 9 GLIS.3 & 0.91 & & & & 30 GL69 & 32.92 & & & \\
\hline 10GL6) 3 & 4.42 & & & & & & & & \\
\hline
\end{tabular}


TABLE A5. Corroding Metal/Aluminum Material by Visual Inspection of Bags (Concluded)

\begin{tabular}{|c|c|c|c|c|c|c|c|c|c|}
\hline $\begin{array}{l}\text { Bag } \\
\text { No. }\end{array}$ & $\begin{array}{l}\text { Tolal } \\
(\mathrm{kg})\end{array}$ & $\begin{array}{c}\text { Estimated } \\
(\mathrm{kg})\end{array}$ & $\begin{array}{c}\text { Actual } \\
(\mathrm{kg})\end{array}$ & $\begin{array}{c}\text { Difference } \\
(\mathrm{kg})\end{array}$ & $\begin{array}{l}\text { Bag } \\
\text { No. }\end{array}$ & $\begin{array}{l}\text { Total } \\
(\mathrm{kg})\end{array}$ & $\begin{array}{c}\text { Estimated } \\
(\mathrm{kg})\end{array}$ & $\begin{array}{c}\text { Actual } \\
(\mathrm{kg})\end{array}$ & $\begin{array}{c}\text { Difference } \\
(k,)\end{array}$ \\
\hline $1 \mathrm{MO65}$ & 2.56 & & & & GHF62 & 3.75 & 0.20 & 0.20 & 0.00 \\
\hline $2 \mathrm{MO65}$ & 2.98 & & & & $7 \mathrm{HF} 62$ & 2.20 & 0.20 & 0.20 & 0.00 \\
\hline $3 \mathrm{MO65}$ & 3.52 & & & & $8 \mathrm{HF} 62$ & 2.11 & 0.20 & 0.20 & 0.00 \\
\hline $4 M 065$ & 3.69 & & & & $9 \mathrm{HF} 62$ & 2.29 & 0.20 & 0.20 & 0.00 \\
\hline $5 M 065$ & 3.13 & & & & $10 \mathrm{HF} 62$ & 2.41 & 0.20 & 0.20 & 0.00 \\
\hline $6 \mathrm{MO} 65$ & 3.20 & & & & $11 \mathrm{HF} 62$ & 2.28 & $(1.20$ & 0.20 & 0,00 \\
\hline $7 M 065$ & 2.87 & & & & $11 N 33$ & 11.25 & & & \\
\hline $8 M 065$ & 1.97 & & & & $11 N 51$ & 5.35 & & & \\
\hline $9 M 065$ & 3.20 & & & & $21 N 51$ & 3.99 & & & \\
\hline ! $(19065$ & 3.76 & & & & $31 N 51$ & 15.24 & & & \\
\hline 1119065 & 3.44 & & & & $41 N 51$ & 14.76 & & & \\
\hline $12 \mathrm{MO} 65$ & 3.33 & & & & $1 \mathrm{RO}$ & 4.53 & & & \\
\hline $14 \mathrm{H} 52$ & 2.23 & 0.20 & 0.20 & $0 .(x)$ & 2R91 & 4.31 & & & \\
\hline $2455 z$ & 2.33 & $\mathrm{NE}$ & 0.20 & $\mathrm{NE}$ & $3 \mathrm{R} 91$ & 2.09 & & & \\
\hline $34 F 52$ & 2.31 & 0.20 & 0.20 & 0.00 & $4 \mathrm{R} 91$ & 2.03 & & & \\
\hline $411 F 52$ & 3.41 & 0.20 & 0.20 & $0 .(x)$ & $.5 \mathrm{R} 91$ & 1.13 & & & \\
\hline SHF52 & 2.29 & 0.20 & 0.20 & $0 .(9)$ & $6 \mathrm{R} 91$ & 1.11 & & & \\
\hline $6+11552$ & 213 & 0.20 & 0.20 & 0.00 & $7 \mathrm{R} 91$ & 6.97 & & & \\
\hline 711552 & 243 & 1.20 & 0.20 & $0.60 !$ & 8R91 & 7.76 & & & \\
\hline $8 H F 52$ & 2.05 & 0.20 & 0.20 & $(1)(x)$ & 9R91 & 3.94 & & & \\
\hline 1)11552 & 2.33 & 020 & 0.20 & 0.60 & $10 R \% 1$ & 11.82 & & & \\
\hline 20111.52 & $1.9 k$ & 0.20 & 0.20 & 0.100 & $\left.11 R^{\prime}\right) 1$ & 7.23 & & & \\
\hline $1145 \leqslant 2$ & 1.99 & 0.20 & 1.20 & $0(x)$ & 1699 & 5.12 & $\mathrm{NE}$ & & \\
\hline $1 \mathrm{HF}: 62$ & 254 & 0.20 & 0.20 & $(1,19)$ & 3699 & 7.29 & $\mathrm{NE}$ & & \\
\hline $2 \mathrm{HF} 62$ & 283 & 0.20 & 020 & $0 .(x)$ & 3699 & 7.65 & $\mathrm{NE}$ & & \\
\hline 311162 & 1.85 & 0.20 & 0.20 & $0.0 \times 1$ & $4(j)$ & 0.59 & $\mathrm{NE}$ & & \\
\hline $4 H F 6 ?$ & 2.56 & 0.20 & (11.2i) & $0.1 \mathrm{k})$ & $x 099$ & 0.24 & $\mathrm{NE}$ & & \\
\hline SHEO? & 1.96 & 0.20 & 11201 & $0 .(x)$ & & & & & \\
\hline
\end{tabular}

NE. Not estmated hes ause of contammatom on outshde of hage 
TABLE A6. Non-Corroding Metal Material by Visual Inspection of Bags

\begin{tabular}{|c|c|c|c|c|c|c|c|c|c|}
\hline $\begin{array}{l}\text { Bag } \\
\text { No. }\end{array}$ & $\begin{array}{l}\text { Total } \\
(\mathrm{kg})\end{array}$ & $\begin{array}{c}\text { Estimated } \\
(\mathrm{kg})\end{array}$ & $\begin{array}{c}\text { Actual } \\
(\mathrm{kg}) \\
\end{array}$ & $\begin{array}{c}\text { Difference } \\
(\mathrm{kg})\end{array}$ & $\begin{array}{l}\text { Bag } \\
\text { No. }\end{array}$ & $\begin{array}{l}\text { Total } \\
\text { (kg) }\end{array}$ & $\begin{array}{c}\text { Estimated } \\
(\mathrm{kg})\end{array}$ & $\begin{array}{c}\text { Actual } \\
(\mathrm{kg})\end{array}$ & $\begin{array}{c}\text { Difference } \\
(\mathrm{kg})\end{array}$ \\
\hline $1 D C 71$ & 32.63 & & & & 9 WC69 & 1.02 & & & \\
\hline $1 D C 45$ & 20.65 & & & & 10 WC 69 & 0.93 & & & \\
\hline $1 \mathrm{WC4} 2$ & 1.33 & & & & 11 WC69 & 2.40 & & & \\
\hline $2 W C 42$ & 0.97 & & & & $12 W C 69$ & 3.52 & & & \\
\hline $3 W C 42$ & 1.04 & & & & 13 WC69 & 0.86 & & & \\
\hline $4 W C 42$ & 2.21 & & & & 14 WC 69 & 0.24 & & & \\
\hline $5 W C 42$ & 3.75 & & & & $15 W C 69$ & 0.47 & & & \\
\hline $6 \mathrm{WC4} 2$ & 2.96 & & & & $1 \mathrm{P} 60$ & 0.27 & & & \\
\hline $7 W C 42$ & 2.08 & & & & $2 \mathrm{P} 60$ & 2.90 & & & \\
\hline $8 W C 42$ & 3.08 & & & & $3 \mathrm{P} 60$ & 0.69 & & & \\
\hline $9 W C 42$ & 2.08 & & & & $4 P 60$ & 0.22 & & & \\
\hline $10 \mathrm{~W} C 42$ & 1.60 & & & & $5 \mathrm{P} 60$ & 0.47 & & & \\
\hline 11 WC42 & 1.31 & & & & $6 \mathrm{P} 60$ & 1.20 & & & \\
\hline $12 W C 42$ & 0.62 & & & & $7 \mathrm{P} 60$ & 0.90 & & & \\
\hline 1 WC 88 & 4.40 & & & & $8 \mathrm{P} 60$ & 1.54 & & & \\
\hline $2 W C 88$ & 3.23 & & & & $9 \mathrm{P} 60$ & 0.32 & & & \\
\hline 3 WCB8 & 4.69 & & & & $10 \mathrm{P} 60$ & 0.57 & & & \\
\hline $4 W C 88$ & 124 & & & & $11 \mathrm{P}^{\prime}(6)$ & 0.70 & & & \\
\hline $5 W C 88$ & 1.07 & & & & $12 \mathrm{P} 60$ & 0.43 & & & \\
\hline 6WC88 & 26.76 & & & & $13 \mathrm{P} 60$ & 0.29 & & & \\
\hline $1 W C 69$ & 2.08 & & & & $14 \mathrm{P} 60$ & 0.68 & & & \\
\hline $2 W(69$ & 2.51 & & & & $15 \mathrm{P} 60$ & 0.21 & & & \\
\hline $3 W 069$ & 0.35 & & & & $16 \mathrm{P} 60$ & 0.38 & & & \\
\hline 4W(6) & 2.05 & & & & $17 \mathrm{P} 60$ & 0.78 & & & \\
\hline $5 W 069$ & 2.45 & & & & $18 \mathrm{P} 60$ & 0.41 & & & \\
\hline $6 W 069$ & 0.35 & & & & $19 P 60$ & 1.11 & & & \\
\hline $7 W 069$ & 1.49 & & & & $20 \mathrm{P}(x)$ & 1.62 & & & \\
\hline swC69 & 1.21 & & & & $21 \mathrm{P} 60$ & 7.03 & & & \\
\hline
\end{tabular}


TABLE A6. Non-Corroding Metal Material by Visual Inspection of Bags (Continued)

\begin{tabular}{|c|c|c|c|c|c|c|c|c|c|}
\hline $\begin{array}{l}\text { Bag } \\
\text { No. }\end{array}$ & $\begin{array}{l}\text { Total } \\
(\mathrm{kg})\end{array}$ & $\begin{array}{l}\text { Estimated } \\
\qquad(\mathrm{kg})\end{array}$ & $\begin{array}{c}\text { Actual } \\
(\mathrm{kg})\end{array}$ & $\begin{array}{l}\text { Difference } \\
(\mathrm{kg})\end{array}$ & $\begin{array}{l}\text { Bag } \\
\text { No. }\end{array}$ & $\begin{array}{l}\text { Total } \\
\text { (kg) }\end{array}$ & $\begin{array}{l}\text { Istimated } \\
(\mathrm{kg})\end{array}$ & $\begin{array}{l}\text { Actual } \\
(\mathrm{kg})\end{array}$ & $\begin{array}{l}\text { Difference } \\
(\mathrm{kg})\end{array}$ \\
\hline $1 \mathrm{M} 89$ & 1.44 & & & & 11 GL.63 & 1.93 & & & \\
\hline $2 \mathrm{M} 89$ & 2.01 & & & & $12 \mathrm{GL} 63$ & 1.47 & & & \\
\hline $3 \mathrm{M} 80$ & 5.80 & & & & $13 \mathrm{GL} 63$ & 0.45 & & & \\
\hline $4 M 89$ & 10.36 & & & & $14 G L 63$ & 1.36 & & & \\
\hline $5 \mathrm{M} \times 9$ & 1.13 & & & & 15 GL63 & 0.2 .3 & & & \\
\hline $6 \mathrm{M} 89$ & 7.60 & & & & $16 \mathrm{GL} 63$ & 0.46 & & & \\
\hline $7 \mathrm{M} 89$ & 5.015 & 0.00 & 1.12 & -1.02 & 17 GL63 & 1.25 & & & \\
\hline $8 M 89$ & 1.13 & & & & $18 \mathrm{GL} 63$ & 0.68 & & & \\
\hline $9 \mathrm{M} 89$ & 0.23 & $\mathrm{NE}$ & & & 19 GL6.3 & 1.36 & & & \\
\hline $10 \mathrm{M} 89$ & 0.91 & NE: & & & 20GL63 3 & 4.99 & & & \\
\hline $11 \mathrm{M} 89$ & 0.23 & NE: & & & $21 \mathrm{GL} 6.3$ & 0.68 & & & \\
\hline $12 \mathrm{M} 89$ & 0.34 & $\mathrm{NE}$ & & & 22 Glo6. 3 & 1.36 & & & \\
\hline $13 \mathrm{M} \times 9$ & 0.45 & $\mathrm{NI}$ & & & $23 \mathrm{GL} 63$ & 0.91 & & & \\
\hline $14 \mathrm{M} \times 9$ & 0.05 & $\mathrm{NE}$ & & & $240.3 L 6.3$ & 1.02 & & & \\
\hline$|M| 6)^{6}$ & 140,39 & $N E$ & 1.112 & NE: & 250163 & 1.02 & 0.01 & 0.11 & -0.10 \\
\hline $1 M \times x$ & 2.17 & & & & $260 \mathrm{il} .63$ & 0.46 & 0.01 & 0.05 & -0.04 \\
\hline $2 \mathrm{M} \times \mathrm{s}$ & 1.06 & & & & 2701663 & 0.23 & $0 .(11$ & 0.02 & $\cdots 0.01$ \\
\hline $3 \mathrm{MKK}$ & 8.06 & & & & $28 \mathrm{GL} .63$ & 0.91 & 0.01 & 0.09 & -0.08 \\
\hline 4njsis & 0.35 & & & & 2901.6 .3 & 0.80 & 0.01 & 0.09 & -0.08 \\
\hline $5 M \times K$ & 9.31 & & & & 3001.63 & 0.46 & 0.01 & 0.05 & -0.044 \\
\hline icilon? & 11.36 & & & & 31631.63 & 0.23 & 0.01 & 0.05 & $-1,04$ \\
\hline 20160.3 & $19.4 x$ & & & & 3201.0 .3 & 0.91 & 0.01 & 0.0 .5 & -0.04 \\
\hline 36il.6.3 & 1.32 & & & & 3301.63 & 0.80 & 0.01 & $(1,07$ & -0.06 \\
\hline $46.10,3$ & 332 & & & & 3401.6 .3 & 0.46 & 0.01 & 0.05 & -0.04 \\
\hline $5(j 1.6 .3$ & 302 & & & & 10124 & 21.14 & & & \\
\hline (xilto.3 & 0.4 .3 & & & & 261.24 & 22.71 & & & \\
\hline 7cilecis & (1) $f(x)$ & & & & $1(31.09)$ & 29.51 & & & \\
\hline$x(i 16) .3$ & 680 & & & & $2(3100)$ & $2 \times, 23$ & & & \\
\hline wril 163 & 0.91 & & & & $361.6)^{6}$ & $32.9 ?$ & & & \\
\hline mocilas & 442 & & & & & & & & \\
\hline
\end{tabular}


TABLE A6. Non-Corroding Metal Material by Visual Inspection of Bags (Concluded)

\begin{tabular}{|c|c|c|c|c|c|c|c|c|c|}
\hline $\begin{array}{l}\text { Bay } \\
\text { No. }\end{array}$ & $\begin{array}{l}\text { Total } \\
(\mathrm{kg})\end{array}$ & $\begin{array}{c}\begin{array}{c}\text { Estimated } \\
(\mathrm{kg})\end{array} \\
\end{array}$ & $\begin{array}{c}\text { Actual } \\
(\mathrm{kg})\end{array}$ & $\begin{array}{c}\text { Difference } \\
(\mathrm{kg})\end{array}$ & $\begin{array}{l}\text { Bag } \\
\text { No. }\end{array}$ & $\begin{array}{l}\text { Total } \\
(\mathrm{kg})\end{array}$ & $\begin{array}{l}\text { Estimated } \\
\quad(\mathrm{kg})\end{array}$ & $\begin{array}{c}\text { Actual } \\
(\mathrm{kg})\end{array}$ & $\begin{array}{l}\text { Difference } \\
(\mathrm{kg})\end{array}$ \\
\hline $1 \mathrm{MO65}$ & 2.56 & & & & $6 \mathrm{HF}^{2} 2$ & 3.75 & & & \\
\hline $2 \mathrm{MO} 65$ & 2.98 & & & & $7 \mathrm{HF} 62$ & 2.20 & & & \\
\hline $3 \mathrm{MO65}$ & 3.52 & & & & $8 \mathrm{HF} 62$ & 2.11 & & & \\
\hline $4 \mathrm{MO65}$ & 3.69 & & & & $94 F 62$ & 2.29 & & & \\
\hline $5 \mathrm{MO65}$ & 3.13 & & & & $10 \mathrm{HF} 62$ & 2.41 & & & \\
\hline $6 \mathrm{MO65}$ & 3.20 & & & & $11 \mathrm{HF} 62$ & 2.28 & & & \\
\hline $7 \mathrm{MO65}$ & 2.87 & & & & IIN33 & 11.25 & 0.00 & 2.72 & -2.72 \\
\hline $8 \mathrm{MO65}$ & 1.97 & & & & 1 IIN51 & 5.35 & 0.25 & 0.15 & +0.10 \\
\hline 9 MO65 & 3.20 & & & & 2 IN51 & 3.99 & & & \\
\hline $10 \mathrm{MO} 65$ & 3.76 & & & & $31 N 51$ & 15.24 & & & \\
\hline $11 \mathrm{MO65}$ & 3.44 & & & & $4 I N 51$ & 14.76 & & & \\
\hline $12 \mathrm{MO} 65$ & 3.33 & & & & 1891 & 4.53 & & & \\
\hline $1 \mathrm{HF} 52$ & 2.23 & & & & $2 \mathrm{R} 91$ & 4.31 & & & \\
\hline $2 \mathrm{HFS2}$ & 2.33 & $\mathrm{NE}$ & & & $3 \mathrm{R} 91$ & 2.09 & & & \\
\hline $3 \mathrm{HF} 52$ & 2.31 & & & & $4 \mathrm{R} 91$ & 2.03 & & & \\
\hline $4 H \mathrm{HF} 52$ & 3.41 & & & & $5 \mathrm{R} 91$ & 1.13 & & & \\
\hline SHF:52 & 2.29 & & & & $\left.6 R^{9}\right) 1$ & 1.11 & & & \\
\hline $6 \mathrm{HF} 52$ & 2.13 & & & & $7 \mathrm{R} 91$ & 6.97 & & & \\
\hline $7 \mathrm{HI} \times 52$ & 2.43 & & & & $8 \mathrm{R} 91$ & 7.76 & & & \\
\hline $811 F 52$ & 2.05 & & & & $9 \mathrm{R} 91$ & 3.94 & & & \\
\hline 911552 & 2.33 & & & & $10 \mathrm{R} 91$ & 11.82 & & & \\
\hline $10 \mathrm{HF} 52$ & 1.98 & & & & $11 \mathrm{R} 91$ & 7.23 & & & \\
\hline $13 \mathrm{HF}: 52$ & 1.49 & & & & 1099 & 5.12 & $\mathrm{NE}$ & & \\
\hline $141 \% 62$ & 2.54 & & & & $2 \mathrm{G}^{99}$ & 7.29 & NE & & \\
\hline $2 \mathrm{HH} 62$ & 2.83 & & & & 3099 & 7.65 & NI: & & \\
\hline $311 \% 62$ & 1.85 & & & & 4099 & 6.59 & $\mathrm{NE}$ & & \\
\hline $4 \mathrm{HF} 62$ & 2.56 & & & & $x G 9$ & 0.24 & NI: & & \\
\hline $5 \mathrm{H} \times 62$ & 1.96 & & & & & & & & \\
\hline
\end{tabular}

NE: - Not estmated hecause of contamination on outside of bags 
TABLE A7. Solid Inorganic Material by Visual Inspection of Bags

\begin{tabular}{|c|c|c|c|c|c|c|c|c|c|}
\hline $\begin{array}{l}\text { Bag } \\
\text { No. }\end{array}$ & $\begin{array}{l}\text { Tot:lal } \\
\text { (kg) }\end{array}$ & $\begin{array}{c}\text { Estimated } \\
(\mathrm{kg})\end{array}$ & $\begin{array}{l}\text { Actual } \\
(\mathrm{kg})\end{array}$ & $\begin{array}{l}\text { Difference } \\
(\mathrm{kg})\end{array}$ & $\begin{array}{l}\text { Bag } \\
\text { No. }\end{array}$ & $\begin{array}{l}\text { Total } \\
(\mathrm{kg})\end{array}$ & $\begin{array}{c}\text { Estimated } \\
(\mathrm{kg})\end{array}$ & $\begin{array}{c}\text { Actual } \\
(\mathrm{kg})\end{array}$ & $\begin{array}{c}\text { Difference } \\
(\mathrm{kg})\end{array}$ \\
\hline $1 D C 71$ & 32.63 & & & & 9WC69 & 1.02 & & & \\
\hline $1 D C 45$ & 20.65 & & & & 10 WC69 & 0.93 & & & \\
\hline $1 \mathrm{WC4} 2$ & 1.33 & & & & 11 WC69 & 2.40 & & & \\
\hline $2 W C 42$ & 0.97 & & & & $12 W C 69$ & 3.52 & & & \\
\hline $3 \mathrm{WC4}$ & 1.04 & & & & 13WC69 & 0.86 & & & \\
\hline $4 \mathrm{WC} 42$ & 2.21 & & & & $14 W C 69$ & 0.24 & & & \\
\hline $5 W C 42$ & 3.75 & & & & $15 W C 69$ & 0.47 & & & \\
\hline $6 \mathrm{WC}^{\prime} \mathrm{C}$ & 2.96 & & & & $1 \mathrm{Pt}(0)$ & 0.27 & & & \\
\hline $7 \mathrm{WC4}$ & 2.08 & & & & 2P60 & 2.90 & & & \\
\hline $8 W C 42$ & 3.08 & & & & $3 \mathrm{P} 60$ & 0.69 & & & \\
\hline $9 \mathrm{WC} 42$ & 2.08 & & & & $4 \mathrm{P} 60$ & 0.22 & & & \\
\hline $10 \mathrm{WC} 42$ & 1.60 & & & & $5 \mathrm{P} 60$ & 0.47 & & & \\
\hline $11 \mathrm{WC} 42$ & 1.31 & & & & $6 \mathrm{P} 60$ & 1.20 & & & \\
\hline $12 \mathrm{WC} 42$ & 0.62 & & & & $7 \mathrm{P} 60$ & 0.90 & & & \\
\hline $1 W C 88$ & 4.40 & & & & $8 \mathrm{P} 60$ & 1.54 & & & \\
\hline $2 W C 88$ & 3.23 & & & & $9 \mathrm{P} 60$ & 0.32 & & & \\
\hline $3 W C 88$ & 4.69 & & & & $10 P 60$ & 0.57 & & & \\
\hline $4 W C 88$ & 1.24 & & & & $11 \mathrm{P} 60$ & 0.70 & & & \\
\hline $5 W C 88$ & 1.07 & & & & $12 \mathrm{P} 60$ & 0.43 & & & \\
\hline $6 W C 88$ & 26.76 & & & & $13 \mathrm{P} 60$ & 0.29 & & & \\
\hline $1 \mathrm{~W}(09$ & 2.08 & & & & i $4 \mathrm{P} 60$ & 0.68 & & & \\
\hline $2 W^{\prime}(60)$ & 2.51 & & & & $15 \mathrm{P} 60$ & 0.21 & & & \\
\hline $3 \mathrm{~W}^{\prime} \mathrm{Cog}$ & 0.35 & & & & $16 \mathrm{P} 60$ & 0.38 & & & \\
\hline $4 W(60)$ & 2.05 & & & & $17 P 60$ & 0.78 & 0.00 & 0.28 & -0.28 \\
\hline $5 W(69$ & 2.45 & & & & $18 P(0)$ & 0.41 & & & \\
\hline $6 W^{\prime}(69$ & 0.35 & & & & $19 \mathrm{P}(x)$ & 1.11 & & & \\
\hline $7 W^{\prime}(0) 9$ & 1.49 & & & & $20 \mathrm{P} 60$ & 1.62 & & & \\
\hline $8 W(60)$ & 1.21 & & & & $21 P(0)$ & 7.03 & & & \\
\hline
\end{tabular}




\section{RFP-4604}

TABLE A7. Solid Inorganic Material by Visual Inspection of Bags (Continued)

\begin{tabular}{|c|c|c|c|c|c|c|c|c|c|}
\hline $\begin{array}{l}\text { Bag } \\
\text { No. }\end{array}$ & $\begin{array}{l}\text { Total } \\
(\mathrm{kg})\end{array}$ & $\begin{array}{c}\text { Estimated } \\
(\mathrm{kg})\end{array}$ & $\begin{array}{c}\text { Actllal } \\
(\mathrm{kg})\end{array}$ & $\begin{array}{c}\text { Difference } \\
(\mathrm{kg})\end{array}$ & $\begin{array}{l}\text { Bag } \\
\text { No. }\end{array}$ & $\begin{array}{l}\text { Total } \\
(\mathrm{kg})\end{array}$ & $\begin{array}{c}\text { Estimated } \\
(\mathrm{kg})\end{array}$ & $\begin{array}{c}\text { Actual } \\
(\mathrm{kg})\end{array}$ & $\begin{array}{c}\text { Difference } \\
(\mathrm{kg})\end{array}$ \\
\hline $1 \mathrm{M} 89$ & 1.44 & & & & $11 \mathrm{GL} 63$ & 1.93 & 1.91 & 1.82 & +0.09 \\
\hline $2 \mathrm{M} 89$ & 2.01 & & & & 12GL63 & 1.47 & 1.46 & 1.41 & +0.114 \\
\hline $3 \mathrm{M} 89$ & 5.80 & & & & $13 \mathrm{GL} 63$ & 0.45 & 0.45 & 0.4 .5 & 0.00 \\
\hline $4 \mathrm{M} 89$ & 10.36 & & & & $14 \mathrm{GL} 63$ & 1.36 & 1.35 & 1.36 & -0.01 \\
\hline $5 \mathrm{M} 89$ & 1.13 & & & & $15 \mathrm{GL} 63$ & 0.23 & 0.22 & 0.23 & -0.01 \\
\hline $6 \mathrm{M} 89$ & 7.60 & & & & $16 \mathrm{GL6} 3$ & 0.46 & 0.45 & 0,46 & $\ldots 0.01$ \\
\hline $7 \mathrm{M} 89$ & 5.05 & & & & $17 \mathrm{GL} 63$ & 1.25 & 1.23 & 1.25 & -0.02 \\
\hline $8 \mathrm{M} 89$ & 1.13 & & & & $18 \mathrm{GL} 63$ & 0.68 & 0.67 & 0.68 & -0.01 \\
\hline $9 \mathrm{M} 89$ & 0.23 & $\mathrm{NE}$ & & & 19 GL.63 & 1.36 & 1.35 & 1.36 & -0.01 \\
\hline $10 \mathrm{M} 89$ & 0.91 & NE & & & $20 \mathrm{GL} 63$ & 4.99 & 4.94 & 4.88 & +0.06 \\
\hline $11 \mathrm{M} 89$ & 0.23 & NI: & & & $21 \mathrm{GL} 63$ & 0.68 & 0.67 & 0.68 & -0.01 \\
\hline $12 \mathrm{M} 89$ & 0.34 & NE & & & 22 GL6 3 & 1.36 & 1.35 & 1.36 & -0.01 \\
\hline $13 \mathrm{M} 89$ & 0.45 & $\mathrm{NE}$ & & & 23GL63 & 0.91 & 0.90 & 0.91 & +0.01 \\
\hline $14 \mathrm{M} 89$ & c: 05 & $\mathrm{NE}$ & & & 24 GL 63 & 1.02 & 1.01 & 1.02 & +0.01 \\
\hline $1 \mathrm{M} 69$ & 140.39 & $\mathrm{NE}$ & & & $25 \mathrm{GL} 63$ & 1.02 & 1.00 & 0.91 & +0.09 \\
\hline $1 \mathrm{M} 88$ & 2.17 & & & & $26 \mathrm{GL} 63$ & 0.46 & 0.44 & 0.41 & +0.03 \\
\hline $2 \mathrm{M} 88$ & 1.06 & & & & 27 GL6. 3 & 0.23 & 0.21 & 0.21 & 0.00 \\
\hline $3 \mathrm{M} 88$ & 8.06 & & & & $28 \mathrm{GL} 63$ & 0.91 & 0.89 & 0.82 & +0.07 \\
\hline $4 \mathrm{M} 88$ & 0.35 & & & & $29 \mathrm{GL6} 63$ & 0.80 & 0.78 & 0.71 & +0.07 \\
\hline $5 \mathrm{M} 88$ & 9.31 & & & & $30 \mathrm{GL} .63$ & 0.46 & 0.44 & 0.41 & +0.013 \\
\hline $1 \mathrm{GL} 63$ & 0.36 & 0.36 & 0.11 & +0.25 & 31 GL63 & 0.23 & 0.44 & 0.41 & +0.03 \\
\hline $2 \mathrm{GL6} 63$ & 0.48 & 0.48 & 0.45 & +0.03 & $32 \mathrm{GL} 63$ & 0.91 & 0.44 & 0.41 & +0.03 \\
\hline $3 \mathrm{Gl} .63$ & 1.32 & 1.32 & 1.32 & 0.00 & 33 GL63 & 0.80 & 0.66 & 0.61 & +0.05 \\
\hline $4 \mathrm{GL} 63$ & 3.32 & 3.00 & 2.87 & +0.13 & $34 \mathrm{GL} 63$ & 0.46 & 0.44 & 0.41 & +0.03 \\
\hline SGL63 & 3.012 & 2.72 & 2.57 & +0.15 & $1 \mathrm{GL} 24$ & 21.14 & 20.34 & 18.24 & +2.10 \\
\hline $6 \mathrm{Gl} 63$ & 0.43 & 0.42 & 0.43 & -0.01 & $2 \mathrm{GL}, 24$ & 22.71 & 21.83 & 21.46 & +0.37 \\
\hline 7 CiLo 3 & 0.60 & 0.59 & 0.45 & +0.14 & 10169 & 29.51 & 28.58 & 28.64 & -0.06 \\
\hline 8 8GL.6.3 & $6.80)$ & 0.73 & 6.69 & +0.04 & 2GL69 & 28.23 & 26.86 & 27.29 & -0.43 \\
\hline 901.16 .3 & 0.91 & 0.90 & 0.91 & -0.01 & 3 GL 69 & 32.92 & 31.55 & 31.71 & -0.16 \\
\hline 30 int6.3 & 4.42 & 4.38 & 4.31 & +0.07 & & & & & \\
\hline
\end{tabular}

Table A7 concluded on following page 
TABLE A7. Solid Inorganic Material by Visual Inspection of Bags (Concluded)

\begin{tabular}{|c|c|c|c|c|c|c|c|c|c|}
\hline $\begin{array}{l}\text { Bag } \\
\text { No. }\end{array}$ & $\begin{array}{l}\text { Total } \\
(\mathrm{kg})\end{array}$ & $\begin{array}{c}\text { Estimated } \\
(\mathrm{kg})\end{array}$ & $\begin{array}{c}\text { Actual } \\
(\mathrm{kg})\end{array}$ & $\begin{array}{c}\text { Difference } \\
(\mathrm{kg})\end{array}$ & $\begin{array}{l}\text { Bag } \\
\text { No. }\end{array}$ & $\begin{array}{l}\text { Total } \\
\left(\mathrm{kg}_{\mathrm{g}}\right)\end{array}$ & $\begin{array}{c}\text { Estimated } \\
(\mathrm{kg})\end{array}$ & $\begin{array}{c}\text { Actual } \\
(\mathrm{kg})\end{array}$ & $\begin{array}{c}\text { Difference } \\
(\mathrm{kg})\end{array}$ \\
\hline $1 M 065$ & 2.56 & 0.00 & 1.65 & -1.65 & $6 \mathrm{HF} 62$ & 3.75 & 0.07 & 0.07 & 0.00 \\
\hline $2 \mathrm{MO65}$ & 2.98 & 0.00 & 2.04 & -2.04 & 7HIF 62 & 2.20 & 0.07 & 0.07 & 0.00 \\
\hline $3 \mathrm{MO65}$ & 3.52 & 0.00 & 2.59 & -2.59 & $8 \mathrm{HF} 62$ & 2.11 & 0.07 & 0.07 & $0,0 \%$ \\
\hline $4 \mathrm{MO65}$ & 3.69 & 0.00 & 2.75 & -2.75 & $9 \mathrm{HF} 62$ & 2.29 & 0.07 & 0.07 & 0.00 \\
\hline 5 MO65 & 3.13 & 0.00 & 2.24 & -2.24 & $10 \mathrm{HF} 62$ & 2.41 & 0.24 & 0.23 & +0.01 \\
\hline $6 \mathrm{MO} 65$ & 3.20 & 0.00 & 2.29 & -2.29 & $11 \mathrm{HF} 62$ & 2.28 & 0.36 & 0.18 & +0.18 \\
\hline $7 \mathrm{MO65}$ & 2.87 & 0.00 & 1.95 & -1.95 & $1 \mathrm{IN} 33$ & 11.25 & 11.25 & 8.53 & +2.72 \\
\hline $8 \mathrm{MO} 65$ & 1.97 & 0.00 & 1.08 & -1.08 & IIN51 & 5.35 & 4.85 & 4.76 & +0.09 \\
\hline $9 \mathrm{MO65}$ & 3.20 & 0.00 & 2.28 & -2.28 & $2 I N 51$ & 3.99 & 1.91 & 3.11 & -1.20 \\
\hline $10 \mathrm{MO} 65$ & 3.76 & 0.00 & 2.83 & -2.83 & $3 I N 51$ & 15.24 & 15.01 & 14.79 & +0.22 \\
\hline $11 \mathrm{MO} 65$ & 3.44 & 0.00 & 2.54 & -2.54 & $4 \mathrm{IN} 51$ & 14.76 & 14.63 & 14.52 & +0.10 \\
\hline $12 \mathrm{MO} 65$ & 3.33 & 0.00 & 2.44 & -2.44 & $1 \mathrm{R} 91$ & 4.53 & 2.85 & 2.64 & +0.21 \\
\hline $1 \mathrm{HF} 52$ & 2.23 & 0.46 & 0.36 & +0.10 & 2R91 & 4.31 & 2.71 & 2.07 & +0.64 \\
\hline $2 \mathrm{HF} 52$ & 2.33 & $N E$ & 0.46 & $\mathrm{NE}$ & $3 \mathrm{R} 91$ & 2.09 & 1.31 & 1.14 & +0.17 \\
\hline $3 \mathrm{HFS2}$ & 2.31 & 0.54 & 0.44 & +0.10 & $4 \mathrm{R} 91$ & 2.03 & 1.28 & 1.14 & +0.14 \\
\hline $4 \mathrm{HF} 52$ & 3.41 & 0.68 & 0.33 & +0.35 & $5 \mathrm{R} 91$ & 1.13 & 0.71 & 0.56 & +0.15 \\
\hline 5HF52 & 2.29 & 0.07 & 0.07 & 0.00 & $6 \mathrm{R} 91$ & 1.11 & 0.70 & 0.57 & +0.13 \\
\hline $6 \mathrm{HF} 52$ & 2.13 & 0.07 & 0.07 & 0.00 & 7R91 & 6.97 & 4.38 & 3.17 & $+i .21$ \\
\hline $7 \mathrm{HFS2}$ & 2.43 & 0.18 & 0.29 & $\ldots 0.11$ & $8 \div 991$ & 7.76 & 4.88 & 4.8 .5 & +0.013 \\
\hline $8 \mathrm{HF} 52$ & 2.05 & 0.07 & 0.07 & 0.00 & 9R91 & 3.94 & 2.48 & 2.28 & $+(0.20$ \\
\hline 9HF52 & 2.33 & 0.07 & 0.07 & 0.00 & $10 \mathrm{R} 91$ & 11.82 & 7.4 .3 & 7.34 & +0.09 \\
\hline $10 \mathrm{HF} 52$ & 1.98 & 0.07 & 0.07 & 0.00 & $11 \mathrm{R} 91$ & 7.23 & 4.54 & 3.71 & +0.83 \\
\hline 11 HF52 & 1.99 & 0.07 & 0.07 & 0.00 & $1 \mathrm{G} 99$ & 5.12 & $\mathrm{NE}$ & 5.07 & NE: \\
\hline $1 \mathrm{HF} 62$ & 2.54 & 0.07 & 0.07 & 0.00 & $2 G(9)$ & 7.29 & $N E$ & 7.24 & NE: \\
\hline $2 \mathrm{HF} 62$ & 2.83 & 0.58 & 0.10 & +0.48 & $3 G 99$ & 7.65 & $\mathrm{NE}$ & 7.60 & $\mathrm{NI}$ \\
\hline $3 \mathrm{HF} 62$ & 1.85 & 0.07 & 0.07 & 0.00 & $4 G 99$ & 6.59 & NE & 5.23 & NE: \\
\hline $4 \mathrm{HF} 62$ & 2.56 & 0.37 & 0.28 & +0.09 & XG99 & 0.24 & NE: & & \\
\hline $5 H F 62$ & 1.96 & 0.07 & 0.07 & $0 .(10)$ & & & & & \\
\hline
\end{tabular}

NE - Not estimated because of contamination on outside of bags 
TABLE A8. Cement Material by Visual Inspection of Bags

\begin{tabular}{|c|c|c|c|c|c|c|c|c|c|}
\hline $\begin{array}{l}\text { Bag } \\
\text { No. }\end{array}$ & $\begin{array}{l}\text { Total } \\
(\mathrm{kg})\end{array}$ & $\begin{array}{c}\text { Estimated } \\
(\mathrm{kg})\end{array}$ & $\begin{array}{c}\text { Actual } \\
(\mathrm{kg})\end{array}$ & $\begin{array}{l}\text { Difference } \\
(\mathrm{kg})\end{array}$ & $\begin{array}{l}\text { Bing } \\
\text { No. }\end{array}$ & $\begin{array}{l}\text { Total } \\
(\mathrm{kg})\end{array}$ & $\begin{array}{l}\text { listimated } \\
(\mathrm{kg})\end{array}$ & $\begin{array}{c}\text { Actual } \\
(\mathrm{kg})\end{array}$ & $\begin{array}{l}\text { Difference } \\
(\mathrm{kg})\end{array}$ \\
\hline $1 D C 71$ & 32.63 & & & & 9 WC69 & 1.02 & & & \\
\hline $1 D C 45$ & 20.65 & & & & $10 \mathrm{~W}(6)$ & 0.93 & & & \\
\hline IWC42 & 1.33 & & & & $11 W 069$ & 2.40 & & & \\
\hline $2 W C 42$ & 0.97 & & & & $12 \mathrm{WC}(09$ & 3.52 & & & \\
\hline $3 \mathrm{WC} 42$ & 1.04 & & & & $13 \mathrm{~W}(69)$ & 0.86 & & & \\
\hline $4 \mathrm{WC4} 2$ & 2.21 & & & & $14 W C 69$ & 0.24 & & & \\
\hline $5 W C 42$ & 3.75 & & & & $15 W C 69$ & 0.47 & & & \\
\hline $6 \mathrm{WC} 42$ & 2.96 & & & & $1 \mathrm{P} 60$ & 0.27 & & & \\
\hline $7 W C 42$ & 2.08 & & & & $2 \mathrm{P} 60$ & 2.90 & 0.15 & 0.23 & -0.08 \\
\hline $8 W C 42$ & 3.118 & & & & $3 \mathrm{P} 60$ & 0.69 & & & \\
\hline $9 W C 42$ & 2.08 & & & & $4 \mathrm{P} 60$ & 0.22 & & & \\
\hline $10 \mathrm{WC} 42$ & 1.60 & & & & $5 \mathrm{P} 60$ & 0.47 & & & \\
\hline $11 W C 42$ & 1.31 & & & & $6 \mathrm{P}^{2} 60$ & 1.20 & & & \\
\hline $12 W C 42$ & 0.62 & & & & $7 P 60$ & 0.90 & & & \\
\hline $1 W C 88$ & 4.40 & & & & $8 P 60$ & 1.54 & & & \\
\hline $2 W C 88$ & 3.2 .3 & & & & $9 P(x)$ & 0.32 & & & \\
\hline 3 WC 88 & 4.69 & & & & $10 \mathrm{P} 60$ & 0.57 & & & \\
\hline $4 W C 88$ & 1.24 & & & & $11 P 60$ & 0.70 & & & \\
\hline SWC88 & 1.17 & & & & $12 \mathrm{P}(60)$ & 0.43 & & & \\
\hline $6 W C 88$ & 26,76 & 0.00 & 11.34 & -11.34 & $1.3 \mathrm{P}(0)$ & 0.29 & & & \\
\hline IWC69 & 2.08 & & & & $14 \mathrm{P}(0)$ & 0.68 & & & \\
\hline $2 W(69$ & 2.51 & & & & $15 \mathrm{P} 60$ & 0.21 & & & \\
\hline $3 W(0)$ & 0.35 & & & & $16 \mathrm{P} 60)$ & 0.38 & & & \\
\hline $4 W(69$ & 2.05 & & & & $17 \mathrm{P} 60$ & 0.78 & & & \\
\hline $5 w^{\prime}(6)$ & 2.45 & & & & $18 \mathrm{P60}$ & 0.41 & & & \\
\hline $6 \mathrm{WC}(0)$ & 0.35 & & & & $19 \mathrm{P} 60$ & 1.11 & & & \\
\hline $7 W(69)$ & 1.49 & & & & $20 \mathrm{Pf}(0)$ & 1.62 & & & \\
\hline $8 W(69)$ & 1.21 & & & & $21 P(0)$ & $7.03,3$ & & & \\
\hline
\end{tabular}


TABLE A8. Cement Material by Visual Inspection of Bags (Continued)

\begin{tabular}{|c|c|c|c|c|c|c|c|c|c|}
\hline $\begin{array}{l}\text { Bag } \\
\text { No. }\end{array}$ & $\begin{array}{l}\text { Total } \\
(\mathrm{kg})\end{array}$ & $\begin{array}{c}\text { Estimated } \\
\left(\mathrm{kg}_{\mathrm{g}}\right)\end{array}$ & $\begin{array}{l}\text { Actual } \\
(\mathrm{kg} !)\end{array}$ & $\begin{array}{l}\text { Difference } \\
\quad(\mathrm{kg})\end{array}$ & $\begin{array}{l}\text { Bug } \\
\text { No, }\end{array}$ & $\begin{array}{l}\text { Total } \\
(\mathrm{kg})\end{array}$ & $\begin{array}{c}\text { Estimated } \\
(\mathrm{kg})\end{array}$ & $\begin{array}{c}\text { Actual } \\
(\mathrm{kg})\end{array}$ & $\begin{array}{l}\text { Difference } \\
(\mathrm{kg})\end{array}$ \\
\hline $1 \mathrm{M} 89$ & 1.44 & & & & 11 GL63 & 1.93 & & & \\
\hline $2 \mathrm{M} 89$ & 2.01 & & & & 12G1.6.3 & 1.47 & & & \\
\hline $3 M 89$ & 5.80 & & & & $13 \mathrm{GL} 63$ & 0.45 & & & \\
\hline $4 \mathrm{M} 89$ & 10.36 & & & & $14 \mathrm{GL} 63$ & 1.36 & & & \\
\hline $5 \mathrm{M} 89$ & 1.13 & & & & $15 \mathrm{GL} 63$ & 0.23 & & & \\
\hline $6 \mathrm{M} 89$ & 7.60 & 1.91 & 2.27 & -0.36 & 16GL6.3 & 0.46 & & & \\
\hline $7 \mathrm{M} 89$ & 5.05 & & & & 17 GL63 & 1.25 & & & \\
\hline $8 \mathrm{M} 89$ & 1.13 & & & & $18 \mathrm{GL} 63$ & 0.68 & & & \\
\hline $9 \mathrm{M} 89$ & 0.23 & $\mathrm{NE}$ & & & 19 GL63 & 1.36 & & & \\
\hline $10 \mathrm{M} 89$ & 0.91 & $\mathrm{NE}$ & & & 20 GL 63 & 4.99 & & & \\
\hline $11 \mathrm{M} 89$ & 0.23 & $\mathrm{NE}$ & & & $210 L 63$ & 0.68 & & & \\
\hline $12 \mathrm{M} 89$ & 0.34 & NE & & & 22GL63 & 1.36 & & & \\
\hline $13 \mathrm{M} 89$ & 0.45 & $\mathrm{NE}$ & & & 23 GL63 & 0.91 & & & \\
\hline $14 \mathrm{M} 89$ & 0.05 & $\mathrm{NE}$ & & & 24 GL 63 & $1 .(02$ & & & \\
\hline $1 \mathrm{M} 69$ & 140.39 & $\mathrm{NE}$ & & & $25 \mathrm{GL} 63$ & 1.02 & & & \\
\hline $1 \mathrm{M} 88$ & 2.17 & & & & $26 \mathrm{GL} 63$ & 0.46 & & & \\
\hline $2 M 88$ & 1.00 & & & & $27 \mathrm{GL} 63$ & 0.23 & & & \\
\hline $3 \mathrm{M} 88$ & 8.06 & 0.00 & 0.4 .5 & -0.45 & $280 \mathrm{GL} 63$ & 0.91 & & & \\
\hline $4 M 88$ & 0.35 & & & & 2961.63 & 0.80 & & & \\
\hline $5 \mathrm{M} \times 8$ & 9.31 & & & & $30 \mathrm{GL} 63$ & 0.46 & & & \\
\hline 1 il.6.6. & 0.36 & & & & 31 GL6. 63 & 0.23 & & & \\
\hline $2 G \mathrm{GL} 63$ & 0.48 & & & & 32 GL6 63 & 0.91 & & & \\
\hline 3CiL6.3 & 1.32 & & & & $3.3 \mathrm{GL} 63$ & 0.80 & & & \\
\hline 4 (il. 6.3 & 3.32 & & & & 34 GL 63 & 0.46 & & & \\
\hline 501.6 .3 & 3.102 & & & & $1 \mathrm{GL} .24$ & 21.14 & & & \\
\hline 6 (j).6.3 & 0.4 .3 & & & & $2 \mathrm{GL} 24$ & 22.71 & & & \\
\hline $7 G \mathrm{GL} 6.3$ & 0.60 & & & & IGL.69 & 29.51 & & & \\
\hline 801.6 .3 & 6.80 & & & & $2(1469$ & 28.23 & & & \\
\hline $90 \mathrm{BL} 163$ & 0.91 & & & & $30106)$ & .32 .92 & & & \\
\hline focil.6i3 & 4.42 & & & & & & & & \\
\hline
\end{tabular}


TABLE A8. Cement Material by Visual Inspection of Bags (Concluded)

\begin{tabular}{|c|c|c|c|c|c|c|c|c|c|}
\hline $\begin{array}{l}\text { Bang } \\
\text { No. }\end{array}$ & $\begin{array}{l}\text { Total } \\
(\mathrm{kg})\end{array}$ & $\begin{array}{c}\text { Estimated } \\
(\mathrm{kg})\end{array}$ & $\begin{array}{c}\text { Actual } \\
(\mathrm{kg})\end{array}$ & $\begin{array}{c}\text { Difference } \\
(\mathrm{kg})\end{array}$ & $\begin{array}{l}\text { Bag } \\
\text { No. }\end{array}$ & $\begin{array}{c}\text { Total } \\
(\mathrm{kg})\end{array}$ & $\begin{array}{c}\text { Estimated } \\
(\mathrm{kg})\end{array}$ & $\begin{array}{c}\text { Actual } \\
(\mathrm{kg})\end{array}$ & $\begin{array}{c}\text { Difference } \\
(\mathrm{kg})\end{array}$ \\
\hline $1 \mathrm{MO} 65$ & 2.56 & & & & $6 \mathrm{HF} 62$ & 3.75 & & & \\
\hline $2 \mathrm{MO} 65$ & 2.98 & & & & $7 \mathrm{HF} 62$ & 2.20 & & & \\
\hline $3 \mathrm{MO65}$ & 3.52 & & & & $8 \mathrm{HF} 62$ & 2.11 & & & \\
\hline $4 \mathrm{MO} 65$ & 3.69 & & & & $9 \mathrm{HF} 62$ & 2.29 & & & \\
\hline $5 \mathrm{MO65}$ & 3.13 & & & & $10 \mathrm{HF} 62$ & 2.41 & & & \\
\hline $6 \mathrm{MO65}$ & 3.20 & & & & $11 \mathrm{HF} 62$ & 2.28 & & & \\
\hline $7 \mathrm{MO} 65$ & 2.87 & & & & IIN33 & 11.25 & & & \\
\hline $8 M 06.5$ & 1.97 & & & & 1IN51 & 5.35 & & & \\
\hline 9 MO65 & 3.20 & & & & 2IN51 & 3.99 & & & \\
\hline $10 \mathrm{MO} 65$ & 3.76 & & & & 3IN5I & 15.24 & & & \\
\hline $11 \mathrm{MO} 65$ & 3.44 & & & & 4IN51 & 14.76 & & & \\
\hline $12 \mathrm{MO} 65$ & 3.33 & & & & $1 \mathrm{R} 91$ & 4.53 & & & \\
\hline $1 \mathrm{HF} 52$ & 2.23 & $\mathrm{NE}$ & & & 2R91 & 4.31 & & & \\
\hline $2 \mathrm{HFS2}$ & 2.33 & & & & $3 \mathrm{R} 91$ & 2.09 & & & \\
\hline $3 \mathrm{HFS2}$ & 2.31 & & & & $4 \mathrm{R} 91$ & 2.03 & & & \\
\hline $4 H F 52$ & 3.41 & & & & $5 \mathrm{R} 91$ & 1.13 & & & \\
\hline $5 H F 52$ & 2.29 & & & & 6R91 & 1.11 & & & \\
\hline $6 \mathrm{HF} 52$ & 2.13 & & & & $7 \mathrm{R} 91$ & 6.97 & & & \\
\hline $7 \mathrm{HF}: 52$ & 2.43 & & & & $8 R 91$ & 7.76 & & & \\
\hline $8 \mathrm{HF} 52$ & 2.05 & & & & 9R91 & 3.94 & & & \\
\hline 9HF52 & 2.33 & & & & 10R91 & 11.82 & & & \\
\hline $10 \mathrm{HF} 52$ & 1.98 & & & & $11 \mathrm{R} 91$ & 7.23 & & & \\
\hline $11 \mathrm{HI}: 52$ & 1.99 & & & & iG99 & 5.12 & $\mathrm{NE}$ & & \\
\hline $1 \mathrm{HF} 62$ & 2.54 & & & & $2 \mathrm{G} 99$ & 7.29 & $\mathrm{NE}$ & & \\
\hline $2 \mathrm{HF}_{62}$ & 2.83 & & & & $3 G 99$ & 7.65 & NE & & \\
\hline $3 H F 62$ & 1.85 & & & & $4 \mathrm{G} 99$ & 6.59 & $\mathrm{NE}$ & & \\
\hline $4 \mathrm{HF} 62$ & 2.56 & & & & XG99 & 0.24 & $\mathrm{NE}$ & & \\
\hline $5 H F 62$ & 1.96 & & & & & & & & \\
\hline
\end{tabular}

NE - Not estimated because of contamination on outside of bags 
TABLE A9. Other Organic Material by Visual Inspection of Bags

\begin{tabular}{|c|c|c|c|c|c|c|c|c|c|}
\hline $\begin{array}{l}\text { Bay } \\
\text { No. }\end{array}$ & $\begin{array}{l}\text { Total } \\
(\mathrm{kg})\end{array}$ & $\begin{array}{c}\text { Estimated } \\
(\mathrm{kg})\end{array}$ & $\begin{array}{c}\text { Actual } \\
(\mathrm{kg})\end{array}$ & $\begin{array}{c}\text { Difference } \\
(\mathrm{kg})\end{array}$ & $\begin{array}{l}\text { Bug } \\
\text { No. }\end{array}$ & $\begin{array}{l}\text { Tolal } \\
(\mathrm{kg})\end{array}$ & $\begin{array}{l}\text { Estimaled } \\
\qquad(\mathrm{kg})\end{array}$ & $\begin{array}{l}\text { Actuil } \\
(\mathrm{kg})\end{array}$ & $\begin{array}{l}\text { Difference } \\
\qquad(\mathrm{kg})\end{array}$ \\
\hline $10 C 71$ & 32.63 & & & & 9WC69 & $1 .(12$ & & & \\
\hline $1 D C 45$ & 20.65 & & & & $10 W(6)$ & 0.93 & & & \\
\hline IWC42 & 1.33 & & & & $11 \mathrm{WC69}$ & 2.40 & & & \\
\hline $2 W C 42$ & 0.97 & & & & $12 W(69)$ & 3.52 & & & \\
\hline $3 W C 42$ & 1.04 & & & & $13 W(69$ & 0.86 & & & \\
\hline $4 W C 42$ & 2.21 & & & & $14 \mathrm{WC6}$ & 0.24 & & & \\
\hline $5 W C 42$ & 3.75 & & & & $15 W(69$ & 0.47 & & & \\
\hline $6 W C 42$ & 2.90 & & & & $1 P 00$ & 0.27 & & & \\
\hline $7 W C 42$ & 2.08 & & & & $2 \mathrm{P}(0)$ & 2.90 & & & \\
\hline $8 W(142$ & 3.08 & & & & $3 P 60$ & 0.69 & & & \\
\hline )WC42 & 2.08 & & & & $4 P 60$ & 0.22 & & & \\
\hline $10 W(42$ & 1.60 & & & & $5 P(60)$ & 0.47 & & & \\
\hline $11 W(42$ & 1.31 & & & & $6 \mathrm{P} 60$ & 1.20 & & & \\
\hline $12 W C 42$ & 0.62 & & & & $7 P(0)$ & 0.90 & & & \\
\hline IWC88 & 4.40 & & & & $8 P 60$ & 1.54 & & & \\
\hline $2 W C 88$ & 3.23 & & & & $9 \mathrm{P}(x)$ & 0.32 & & & \\
\hline $3 W C 88$ & 4.69 & & & & $10 P(0)$ & 0.57 & & & \\
\hline $4 W C 88$ & 1.24 & & & & $11 P(0)$ & 0.70 & & & \\
\hline swCse & 1.07 & & & & $12 P^{2} 60$ & 0.4 .3 & & & \\
\hline 6 6C8 & 26.76 & & & & $13 P 60$ & 0.29 & & & \\
\hline $1 W(60)$ & 2.08 & & & & $14 \mathrm{PO} 0$ & 0.68 & & & \\
\hline $2 \mathrm{~W}(60)$ & 2.51 & & & & $1.5 P(6)$ & 0.21 & & & \\
\hline $3 W(60)$ & 0.35 & & & & $16 \mathrm{P}(0)$ & 0.38 & & & \\
\hline $4 W(60)$ & 2.05 & & & & $17 \mathrm{P}(0)$ & 0.78 & & & \\
\hline $5 W(64$ & 2.45 & & & & $18 \mathrm{P} 60$ & 0.41 & & & \\
\hline (i) & 0.3 .5 & & & & $19 P(0)$ & 1.11 & & & \\
\hline $7 W(60)$ & 1.49 & & & & $20 \mathrm{P}(60)$ & 1.62 & & & \\
\hline$X W(0,0)$ & 1.21 & & & & $21 \mathrm{P}(1)$ & 7.0 .3 & & & \\
\hline
\end{tabular}


TABLE A9. Other Organic Material by Visual Inspection of Bags (Continued)

\begin{tabular}{|c|c|c|c|c|c|c|c|c|c|}
\hline $\begin{array}{l}\text { Bag } \\
\text { No. }\end{array}$ & $\begin{array}{l}\text { Toral } \\
(\mathrm{kg})\end{array}$ & $\begin{array}{l}\text { Estimated } \\
(\mathrm{kg})\end{array}$ & $\begin{array}{c}\text { Actual } \\
(\mathrm{kg})\end{array}$ & $\begin{array}{l}\text { Difference } \\
(\mathrm{kg})\end{array}$ & $\begin{array}{l}\text { Bag } \\
\text { No. }\end{array}$ & $\begin{array}{l}\text { Total } \\
\text { (kg) }\end{array}$ & $\begin{array}{l}\text { Estimaled } \\
(\mathrm{kg})\end{array}$ & $\begin{array}{l}\text { Actual } \\
(\mathrm{kg})\end{array}$ & $\begin{array}{l}\text { Difference } \\
\qquad(\mathrm{k} g)\end{array}$ \\
\hline $1 \mathrm{M} 89$ & 1.44 & & & & $11 \mathrm{GL} 63$ & 1.93 & & & \\
\hline $2 M 89$ & 2.01 & & & & $12 \mathrm{GLG} 3$ & 1.47 & & & \\
\hline $3 \mathrm{M} 89$ & 5.80 & & & & $13 \mathrm{GL} 63$ & 0.45 & & & \\
\hline $4 \mathrm{M} 89$ & 10.36 & & & & 14GL63 & 1.36 & & & \\
\hline SM89 & 1.13 & & & & $15 \mathrm{GL} 63$ & 0.23 & & & \\
\hline $6 \mathrm{M} 89$ & 7.60 & & & & 16GL63 & 0.46 & & & \\
\hline $7 M 89$ & 5.05 & & & & $17 \mathrm{GL63}$ & 1.25 & & & \\
\hline $8 \mathrm{M} 89$ & 1.13 & & & & $18 \mathrm{GL} 63$ & 0.68 & & & \\
\hline $9 M 89$ & 0.23 & $\mathrm{NE}$ & & & 19GL63 & 1.36 & & & \\
\hline $10 \mathrm{M} 89$ & 0.91 & $\mathrm{NE}$ & & & 20GL63 & 4.99 & & & \\
\hline $11 \mathrm{M} 89$ & 0.23 & $N E$ & & & 21 GL63 & 0.68 & & & \\
\hline $12 \mathrm{M} 89$ & 0.34 & $\mathrm{NE}$ & & & 22 GL6 3 & 1.36 & & & \\
\hline $13 \mathrm{M} 89$ & 0.45 & $N E$ & & & 23 GL63 & 0.91 & & & \\
\hline $14 \mathrm{M} 89$ & 0.05 & $\mathrm{NE}$ & & & $24 \mathrm{GL} 63$ & 1.02 & & & \\
\hline $1 \mathrm{M} 69$ & 140.39 & $N E$ & & & 25 GL 6.3 & 1.02 & & & \\
\hline $1 \mathrm{M} 88$ & 2.17 & & & & 26 GL.63 & 0.46 & & & \\
\hline $2 \mathrm{M} 88$ & 1.06 & & & & 27GL63 & 0.23 & & & \\
\hline $3 \mathrm{M} 88$ & 8.06 & & & & $28 \mathrm{GL} 63$ & 0.91 & & & \\
\hline $4 \mathrm{M} 88$ & 0.35 & & & & 29 GL63 & 0.80 & & & \\
\hline $5 \mathrm{M} 88$ & 9.31 & & & & $30 \mathrm{GL} 63$ & 0.46 & & & \\
\hline $1 G L 63$ & 0.36 & & & & $31 \mathrm{GL} 63$ & 0.23 & & & \\
\hline $2 \mathrm{GL} 63$ & 0.48 & & & & 32 GL 63 & 0.91 & & & \\
\hline $3 \mathrm{GL} .63$ & 1.32 & & & & $33 \mathrm{GL} 63$ & 0.80 & & & \\
\hline 4 GLL63 & 3,32 & & & & $34 \mathrm{GL} 63$ & 0.46 & & & \\
\hline $5 \mathrm{GLG} 3$ & 3.02 & & & & $1 G L 24$ & 21.14 & & & \\
\hline GGL63 & 0.43 & & & & $2 \mathrm{GL} 24$ & 22.71 & & & \\
\hline 7 GL63 & 0.60 & & & & $1 \mathrm{GL} 69$ & 29.51 & & & \\
\hline 8 CiL63 & 6.80 & 0.00 & 1.25 & -1.25 & $20 \mathrm{GL} 69$ & 28.23 & & & \\
\hline 9 GLl63 & 0.91 & & & & 3 GL.69) & 32.92 & & & \\
\hline $10 G L 63$ & 4.42 & & & & & & & & \\
\hline
\end{tabular}


TABLL: A9. Other Organic Material by Visual Inspection of Bags (Concleded)

\begin{tabular}{|c|c|c|c|c|c|c|c|c|c|}
\hline $\begin{array}{l}\text { Bing } \\
\text { No. }\end{array}$ & $\begin{array}{l}\text { Tholill } \\
(\mathrm{kg})\end{array}$ & $\begin{array}{l}\text { listimated } \\
(\mathrm{kg} g)\end{array}$ & $\begin{array}{c}\text { Acilual } \\
(\mathrm{kg})\end{array}$ & $\begin{array}{c}\text { Difference } \\
(k p)\end{array}$ & $\begin{array}{l}\text { Bag! } \\
\text { No. }\end{array}$ & $\begin{array}{l}\text { Julal } \\
(k g !)\end{array}$ & $\begin{array}{c}\text { Estmated } \\
(k g)\end{array}$ & $\begin{array}{c}\text { Actual } \\
(\mathrm{kg})\end{array}$ & $\begin{array}{c}\text { Difference } \\
(\mathrm{k} ! \mathrm{l})\end{array}$ \\
\hline $1 \mathrm{MO} 0.5$ & 2.56 & & & & 011102 & 3.75 & 1.29 & 1.67 & $-1) .38$ \\
\hline $2 M 00.5$ & 2.98 & & & & 711162. & 2.20 & & & \\
\hline $3 \mathrm{MO}(5.5$ & 3.52 & & & & $8111 \% 12$. & 2.11 & & & \\
\hline $4 \mathrm{MO} 6.5$ & 3.64 & & & & $9 H 1102$ & 2.29 & & & \\
\hline $5 \mathrm{MO}) 5$ & 3.13 & & & & 1011162 & 2.41 & & & \\
\hline $6 \mathrm{MO} 65$ & 3.20 & & & & 11111062 & $2.2 x$ & & & \\
\hline $7 M O 6.5$ & 2.87 & & & & $11 \mathrm{~N} .3 .3$ & 11.25 & & & \\
\hline 8400.5 & 1.97 & & & & $11 N .51$ & 5.35 & & & \\
\hline $9 \mathrm{MO} 0.5$ & 3.20 & & & & $2 \mid N 51$ & 3.94 & & & \\
\hline $10 \mathrm{M} 00.5$ & 3.76 & & & & $31 N 51$ & 15.24 & & & \\
\hline $11 \mathrm{MO} 06.5$ & 3.44 & & & & $41 N 51$ & 14.76 & & & \\
\hline $12 \mathrm{MO} 6.5$ & 3.3 .3 & & & & |RO1 & 4.53 & & & \\
\hline $1111: 52$ & 2.23 & & & & 2RO1 & 4.31 & & & \\
\hline 241552 & 2.33 & NI: & & & $3 \mathrm{R} 91$ & 2.00 & & & \\
\hline $3111: 52$ & 2.31 & & & & $4 \mathrm{R} 91$ & 2.113 & & & \\
\hline $4111: 52$ & 3.41 & & & & $5 R(9)$ & 1.13 & & & \\
\hline SHIF.5: & 2.29 & & & & $\left.6 R^{9}\right) 1$ & 1.11 & & & \\
\hline $6111: 52$ & 2.13 & & & & $7 \mathrm{k} 91$ & 0.97 & & & \\
\hline 7111152 & 2.4 .3 & & & & $8 R 91$ & 7.76 & & & \\
\hline 8111.52 & 2.05 & & & & (IROI & 3.94 & & & \\
\hline $9111: 52$ & 2.33 & & & & $\left|\left(\mid R^{0}\right)\right|$ & 11.82 & & & \\
\hline 10111552 & 1.98 & & & & $|1 \mathrm{R} 9|$ & 7.23 & & & \\
\hline 1111152 & 1.99 & & & & 1609 & 5.12 & Nl: & & \\
\hline 1111002 & 2.54 & & & & $2(i 90)$ & 7.29 & $\mathrm{Nl}$ & & \\
\hline 2111602 & 2.8 .3 & & & & $3(j(0)$ & 7.65 & NI: & & \\
\hline $311762=$ & 1.85 & & & & $4(j 3)$ & 6.59 & $\mathrm{Nl:}$ & & \\
\hline $4111: 62$ & 2.56 & & & & $x(j) 9$ & 0.24 & $\mathrm{NL}$ & & \\
\hline $5111: 62$ & 1.96 & & & & & & & & \\
\hline
\end{tabular}

NI: Nol estmated because of combanination on ourside of hags 
TABLE A 10. Unknown Composition Material by Visual Inspection of Bags

\begin{tabular}{|c|c|c|c|c|c|c|c|c|c|}
\hline $\begin{array}{l}\text { Bag } \\
\text { No. }\end{array}$ & $\begin{array}{l}\text { Total } \\
(\mathrm{kg}) \\
\end{array}$ & $\begin{array}{c}\begin{array}{c}\text { Estimated } \\
(\mathrm{kg})\end{array} \\
\end{array}$ & $\begin{array}{c}\text { Aclual } \\
(\mathrm{kg})\end{array}$ & $\begin{array}{c}\text { Difference } \\
(\mathrm{kg})\end{array}$ & $\begin{array}{l}\text { Bag } \\
\text { No. }\end{array}$ & $\begin{array}{l}\text { Total } \\
\text { (kg) }\end{array}$ & $\begin{array}{c}\text { Estimated } \\
(\mathrm{kg})\end{array}$ & $\begin{array}{c}\text { Actual } \\
(\mathrm{kg})\end{array}$ & $\begin{array}{c}\text { Difference } \\
(\mathrm{kg})\end{array}$ \\
\hline $1 D C 71$ & 32.63 & 16.32 & 0.00 & +16.32 & $9 W(69$ & 1.02 & & & \\
\hline $1 D C 45$ & 20.65 & $\$, 16$ & 0.00 & +5.16 & $10 \mathrm{WC69}$ & 0.9 .3 & & & \\
\hline $1 W C 42$ & 1.33 & & & & $11 \mathrm{WC} 69$ & 2.40 & & & \\
\hline $2 W C 42$ & 0.97 & & & & $12 W(69)$ & 3.52 & & & \\
\hline $3 W C_{4} 2$ & 1.04 & & & & $13 W(69$ & 0.86 & & & \\
\hline $4 \mathrm{WC4} 2$ & 2.21 & & & & $14 \mathrm{~W}(69)$ & 0.24 & & & \\
\hline $5 W C 42$ & 3.75 & & & & $15 \mathrm{WC} 69$ & 0.47 & & & \\
\hline $6 \mathrm{WC} 42$ & 2.96 & & & & $1 \mathrm{P} 60$ & 0.27 & & & \\
\hline $7 \mathrm{WC} 42$ & 2.08 & & & & $2 P 60$ & 2.90 & & & \\
\hline $8 W C 42$ & 3.08 & & & & $3 \mathrm{P} 60$ & 0.69 & & & \\
\hline $9 \mathrm{WC} 42$ & 2.188 & & & & $4 P(0)$ & 0.22 & & & \\
\hline $10 \mathrm{WC4} 2$ & 1.60 & & & & $5 \mathrm{P} 60$ & 0.47 & & & \\
\hline 11 WC42 & 1.31 & & & & $6 \mathrm{P} 60$ & 1.20 & & & \\
\hline $12 W(42$ & 0.62 & & & & $7 \mathrm{P} 60$ & 0.90 & & & \\
\hline 1 WC88 & 4.40 & & & & $8 P 60$ & 1.54 & & & \\
\hline $2 W C 88$ & 3.23 & & & & $9 \mathrm{P} 60$ & 0.32 & & & \\
\hline 3 WC8 8 & 4.69 & & & & $10 P(0)$ & 0.57 & & & \\
\hline 4WC88 & 1.24 & & & & $11 P 60$ & 0.70 & & & \\
\hline $.5 W C 88$ & 1.07 & & & & $12 \mathrm{P} 60$ & 0.43 & & & \\
\hline 6 WCs8 & 26.76 & & & & $13 \mathrm{P}(0)$ & 0.29 & & & \\
\hline $1 W(69)$ & 2.08 & & & & $14 \mathrm{P} 60$ & 0.68 & & & \\
\hline $2 W 069$ & 2.51 & & & & $15 \mathrm{P} 60$ & 0.21 & & & \\
\hline $3 W(09)$ & 0.35 & & & & $16 P^{2} 60$ & 0.38 & & & \\
\hline AWC69 & 2.115 & & & & $17 P(x)$ & 0.78 & & & \\
\hline $5 W(69$ & 2.4 .5 & & & & $18 \mathrm{P}(00)$ & 0.41 & & & \\
\hline $6 \mathrm{WC}^{\circ 9}$ & 0.35 & & & & $10 \mathrm{P}(0)$ & 1.11 & & & \\
\hline $7 W(69)$ & 1.49 & & & & 20100 & 1.62 & & & \\
\hline $8 W(0)$ & 1.21 & & & & $21 \mathrm{P} 60$ & 7.03 & & & \\
\hline
\end{tabular}


'TABLI: A 10. Unknown Composition Material by' Visual Inspection of Bags (Continued)

\begin{tabular}{|c|c|c|c|c|c|c|c|c|c|}
\hline $\begin{array}{l}\text { Bag } \\
\mathrm{Nol}\end{array}$ & $\begin{array}{l}\text { Thlal } \\
\text { (k!) }\end{array}$ & $\begin{array}{l}\text { Esimated } \\
\text { (kg) }\end{array}$ & $\begin{array}{l}\text { Actual } \\
\text { (k:) }\end{array}$ & $\begin{array}{l}\text { Difference } \\
(\mathrm{kg})\end{array}$ & $\begin{array}{l}\text { Bag } \\
\text { No. }\end{array}$ & $\begin{array}{l}\text { Total } \\
(\mathrm{kg})\end{array}$ & $\begin{array}{l}\text { Estimated } \\
(k g)\end{array}$ & $\begin{array}{c}\text { Actual } \\
(\mathrm{kg})\end{array}$ & $\begin{array}{l}\text { Difference } \\
\text { (kg) }\end{array}$ \\
\hline $1 \mathrm{M} \times 9$ & 1.4 .4 & & & & 11 Gil.6? & 1.93 & & & \\
\hline $2 \mathrm{M} \times 9$ & 201 & & & & 1201.63 & 1.47 & & & \\
\hline $3 \mathrm{M}: 4$ & 5.80 & & & & 1301063 & 0.45 & & & \\
\hline $4 M(89)$ & 10.30 & & & & 1.401 .63 & 1.36 & & & \\
\hline $5 M 89$ & 1.13 & & & & $15 \mathrm{GI} .63$ & 0.23 & & & \\
\hline $6 M 89$ & 7.60 & & & & 10001.63 & 0.46 & & & \\
\hline $7 \mathrm{M} \times 9$ & 5.05 & & & & 1701.63 & 1.25 & & & \\
\hline $8 M 139$ & 1.13 & & & & $186 i 1.63$ & 0.68 & & & \\
\hline $\left.9 M 8^{6}\right)$ & 0.2 .3 & $\mathrm{NE}$ & & & 19 Gilo 3 & 1.36 & & & \\
\hline $10 \mathrm{M} 89$ & 0.91 & NE: & & & $20(31.63$ & 4.99 & & & \\
\hline 111989 & 0.23 & NI: & & & 21010.3 & 0.68 & & & \\
\hline $12 M 89$ & (1).34 & $N E$ & & & $22(j 1.63$ & 1.36 & & & \\
\hline 1.39189 & 01.45 & $\mathrm{NL}$ & & & 2361.63 & 0.91 & & & \\
\hline $14 M k^{9}$ & 0.05 & NE: & & & 2461163 & 1.172 & & & \\
\hline $\left.1 \mathrm{M}^{4}\right)$ & 1.41 .34 & & & & $25(3163$ & 1.02 & & & \\
\hline 1988 & 2.17 & & & & 260116.3 & 0.40 & & & \\
\hline $2 \mathrm{M} \times \mathrm{B}$ & 1.160 & & & & $27(j L 6.3$ & 0.2 .3 & & & \\
\hline $3 M+B$ & x.tot & 1.61 & 0.100 & +1.61 & $2 k G 1.03$ & 041 & & & \\
\hline $411 \times 8$ & 11.35 & & & & 2901613 & 0.80 & & & \\
\hline $5 M \times 88$ & $9 . i 1$ & & & & 3110103 & (1. 40 & & & \\
\hline 131.6 .3 & 0.36 & & & & 31011.63 & (1).23 & & & \\
\hline $2(3) 63$ & $11.4 x$ & & & & 326010.3 & (1)1 & & & \\
\hline $3(31.6 .3$ & 132 & & & & $3.3(31.03 .3$ & 0.80 & & & \\
\hline $4(i)+1,3$ & 33 & & & & $34(31.63$ & 0.46 & & & \\
\hline 56160 & $: 112$ & & & & 101.24 & 21.14 & & & \\
\hline urito: & 1143 & & & & $2(31.24$ & 22.71 & & & \\
\hline$x(1,1\}$, & $0(x)$ & & & & $\mid(3 \mid 0,09$ & 29.51 & & & \\
\hline mintis? & $(1 \times 1)$ & & & & $2(i 109$ & 28.23 & & & \\
\hline$y(i t)$ ? & $1: 41$ & & & & Sol $\mathrm{fr}^{4}$ & 3292 & & & \\
\hline morin: & 442 & & & & & & & & \\
\hline
\end{tabular}




\section{RFP-4604}

TABLE A10. Unknown Composition Material by Visual Inspection of Bags (Concluded)

\begin{tabular}{|c|c|c|c|c|c|c|c|c|c|}
\hline $\begin{array}{l}\text { Bag } \\
\text { No. }\end{array}$ & $\begin{array}{l}\text { Total } \\
\text { (kg) }\end{array}$ & $\begin{array}{c}\text { Estimated } \\
(\mathrm{kg})\end{array}$ & $\begin{array}{c}\text { Actual } \\
(k g)\end{array}$ & $\begin{array}{l}\text { Difference } \\
(k !)\end{array}$ & $\begin{array}{l}\text { Ba! } \\
\text { No! }\end{array}$ & $\begin{array}{l}\text { Total } \\
(\mathrm{kg})\end{array}$ & $\begin{array}{c}\text { Estimated } \\
(\mathrm{kg})\end{array}$ & $\begin{array}{c}\text { Actual } \\
(\mathrm{kg})\end{array}$ & $\begin{array}{c}\text { Differesce } \\
(\mathrm{kg})\end{array}$ \\
\hline $1 \mathrm{MO}, 5$ & 2.56 & 1.58 & $0 .(1)$ & +1.58 & GIIF62 & 3.7 .5 & & & \\
\hline $2 \mathrm{MOO6.5}$ & 2.98 & 1.95 & $0 .(1)$ & +1.95 & $7 \mathrm{HF} 62$ & 2.20 & & & \\
\hline $3 \mathrm{MOO} .5$ & 3.52 & 2.51 & (1)(H) & +2.51 & $81 \mathrm{~F} 62$ & 2.11 & & & \\
\hline $4 M 065$ & 3.69 & 2.69 & $0.06)$ & +2.60 & 9HF6? & 2.29 & & & \\
\hline $5 \mathrm{MO} 65$ & 3.13 & $2.1 ?$ & $0.06)$ & +2.12 & $1011 \% 62$ & 2.41 & & & \\
\hline $6 \mathrm{MOK} .5$ & 3.20 & 2.20 & $0.00)$ & +2.20 & 11HF6? & 2.28 & & & \\
\hline $7 M 06.5$ & 2.87 & 1.84 & 0.000 & +1.84 & $1 \mathrm{IN} 3.3$ & 11.25 & & & \\
\hline $8 M 06.5$ & 1.97 & 0.9 .3 & $0 .(H)$ & $+(1.93$ & $11 N 51$ & 5.35 & & & \\
\hline 99065 & 3.20 & 2.20 & 0.00 & +2.20 & $21 N 51$ & 3.99 & & & \\
\hline 101906.5 & 3.76 & 2.74 & 0.100 & +2.74 & $31 N 51$ & 15.24 & & & \\
\hline $11 \mathrm{MOO65}$ & 3.44 & 2.43 & $0(00)$ & +2.4 .3 & AINSI & 14.76 & & & \\
\hline $12 M 106.5$ & 3.33 & 2.32 & $0 .(i)$ & +2.32 & $|\mathrm{R} 9|$ & 4.5 .3 & & & \\
\hline 1111.52 & 2.23 & & & & $2 R 91$ & 4.31 & & & \\
\hline $2 H 552$ & 2.33 & $\mathrm{NE}$ & & & $3 R 91$ & 2.04 & & & \\
\hline $3 H 1: 52$ & 2.31 & & & & $\{k 9\}$ & $2 .(13)$ & & & \\
\hline $4 H F 52$ & 3.41 & & & & $5 R 91$ & 1.13 & & & \\
\hline $511+52$ & 2.24 & & & & $6 R 91$ & 1.11 & & & \\
\hline 611152 & 2.13 & & & & $7 \mathrm{~K} \%$ & 0.97 & & & \\
\hline $7111: 52$ & 2.4 .3 & & & & $8 R 91$ & 7.76 & & & \\
\hline XHF:5I & 2.145 & & & & $9 R 91$ & 3.94 & & & \\
\hline 9HI:S? & 2.3 .3 & & & & $\left.10 R^{9}\right) 1$ & 11.82 & & & \\
\hline $101+1+52$ & 198 & & & & $11 R D !$ & 7.2 .3 & & & \\
\hline $111+152$ & 194 & & & & 1694 & 5.12 & $\mathrm{NI}$ & & \\
\hline $11+102$ & 2.4 .4 & & & & $2(i 03)$ & 7.29 & $\mathrm{Nl}$ & & \\
\hline 21116.2 & 283 & & & & $3(\mathrm{j} \%)$ & 76.5 & NL: & & \\
\hline $3111 \cdot 62$ & 185 & & & & $f(j \%)$ & 6.59 & $\mathrm{NE}$ & & \\
\hline $4 H[! \cdot 6 ?$ & $296:$ & & & & $x(j(x)$ & 1124 & $V I:$ & & \\
\hline $5+1162$ & 136 & & & & & & & & \\
\hline
\end{tabular}

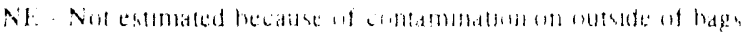



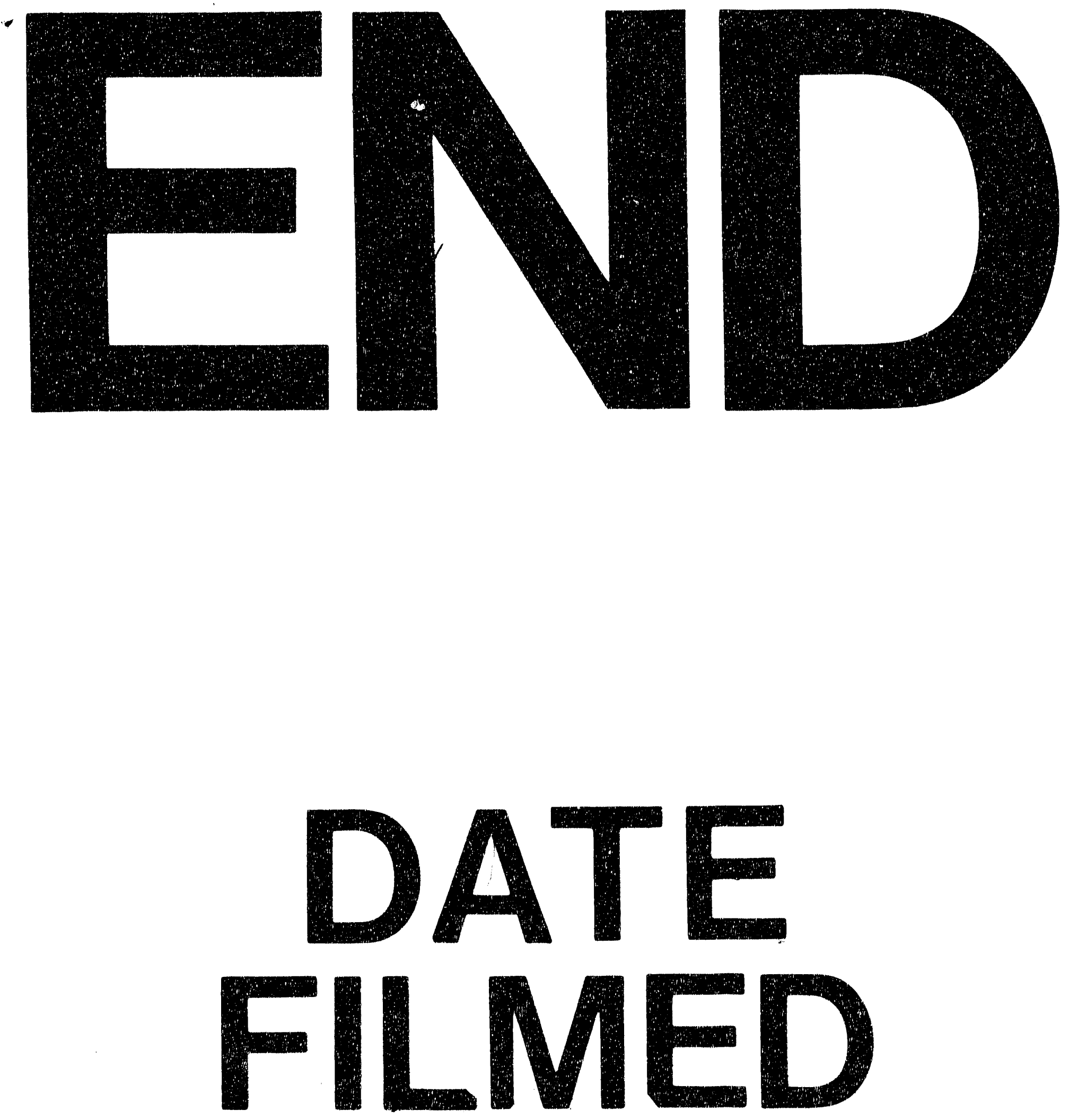

衰

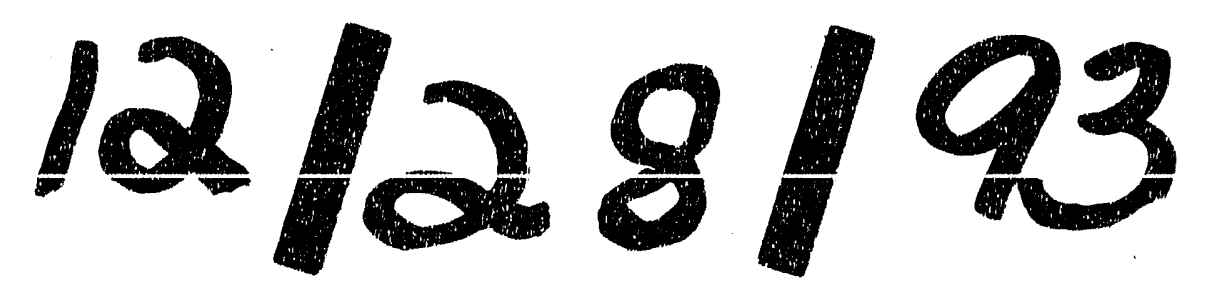


